\title{
Non-heart-beating kidney donors : clinical implications
}

Citation for published version (APA):

Daemen, J. W. H. C. (1998). Non-heart-beating kidney donors : clinical implications. [Doctoral Thesis, Maastricht University]. Universiteit Maastricht. https://doi.org/10.26481/dis.19981023jd

Document status and date:

Published: 01/01/1998

DOI:

10.26481/dis.19981023jd

Document Version:

Publisher's PDF, also known as Version of record

\section{Please check the document version of this publication:}

- A submitted manuscript is the version of the article upon submission and before peer-review. There can be important differences between the submitted version and the official published version of record.

People interested in the research are advised to contact the author for the final version of the publication, or visit the DOI to the publisher's website.

- The final author version and the galley proof are versions of the publication after peer review.

- The final published version features the final layout of the paper including the volume, issue and page numbers.

Link to publication

\footnotetext{
General rights rights.

- You may freely distribute the URL identifying the publication in the public portal. please follow below link for the End User Agreement:

www.umlib.nl/taverne-license

Take down policy

If you believe that this document breaches copyright please contact us at:

repository@maastrichtuniversity.nl

providing details and we will investigate your claim.
}

Copyright and moral rights for the publications made accessible in the public portal are retained by the authors and/or other copyright owners and it is a condition of accessing publications that users recognise and abide by the legal requirements associated with these

- Users may download and print one copy of any publication from the public portal for the purpose of private study or research.

- You may not further distribute the material or use it for any profit-making activity or commercial gain

If the publication is distributed under the terms of Article $25 \mathrm{fa}$ of the Dutch Copyright Act, indicated by the "Taverne" license above, 
NON-HEART-BEATING KIDNEY DONORS

- CLINICAL IMPLICATIONS -

J.H.C. Daemen 


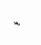




\section{NON-HEART-BEATING KIDNEY DONORS}

\section{- CLINICAL IMPLICATIONS -}

\section{PROEFSCHRIFT}

ter verkrijging van de graad van doctor aan de Universiteit Maastricht, op gezag van de Rector Magnificus, Prof. dr. A.C. Nieuwenhuijzen Kruseman, volgens het besiuit van het College van Decanen, in het openbala te verdedigen op vrijdag 23 oktober 1998 om 14.00 uur door

Jan-Willem Henri Catharina Daemen geboren te Geleen op 18 maart 1966 
Promotor:

Prof. dr. G. Kootstra

Beoordelingscommissie:

Prof. dr. J.W. Arends (voorzitter)

Prof. dr. H.W. van den Bome

Prof, dr. R. Van Hee (Academisch Heelkundig Centrum Stuivenberg, Amwerp, Belgium) Prof. dr. J.P. van Hooff

Mr. M.L. Nicholson (Leicester General Hospital, Leicester, United Kingdom)

De productie van dit proefschrift is mogelijk geweest dankzij de financiële ondersteuning van Biotrin International en de Nierstichting Nederland 
voor Mirjam 
Chapter One

Chapter Two

Chapter Three

Chapter Four

Chapter Five

Chapter Six

Chapter Seven

Chapter Eight
Procurement and Transplantation of Kidneys from Non-Heart-Beating Donors - An Overview -

Categories of Non-Heart-Beating Donors

The Potential Pool of Non-Heart-Beating Kidney Donors

Short-term Outcome of Kidney Transplants from Non-Heart-Beating Donors after Preservation by Machine Perfusion

Effect of Machine Perfusion Preservation on Delayed Graft Function in NonHeart-Beating Donor Kidneys

Viability Testing During Organ Preservation - An Introduction -

Glutathione S-transferase as Predictor of Functional Outcome in Transplantation of Machine Preserved Non-Heart-Beating Donor Kidneys.

Summary and Conclusions / Samerviatting en Conclusies

Publications

Abbreviations

Dankwoond

Curriculum Vitae 


\section{PROCUREMENT AND TRANSPLANTATION OF KIDNEYS FROM NON-HEART-BEATING DONORS}

- an overview -

from: Procurement and Transplantation of Kidneys from Non-Heart-Beating Donors JHC Daemen, APA Oomen, EHJ Belgers, G Kootstra Digestive Surgery 1997; 842: 333-343 


\section{Introduction}

Progress in transplantation medicine, mainly as a result of improving immunosuppressive treatment and. HLA matching has made kidney transplantation more and more acceptable as a routhe treatment for patients with end-stage renal failure. Today, resulits in kidney transplantation are impressiwe; over the years the 1-year graft survival for cadaveric donors reached $80 \%$ and the 1-year patient survival $95 \%$ [1].

A successful kidney transplantation results in improved quality of life for the patient and reduces the costs of treatment of end-stage renal failure. However, transplant numbers cannot keep up with the demand and waiting lists are growing as organ procurement rates are not increasing. Within Eurotransplant (ET), the exchange organisation of the countries of Austria, Belgium, Germany, Luxembourg and The Netherlands, kidney recovery rates decreased 10\% in 1994 when compared to 1993. In 1996, still this rate is $7 \%$ below the lewel of 1993 . As a result, the gap between organs available and patients awaiting kidney transplantation widened; and by the end of 1996, 11,000 patients were on the renal transplant waiting list, while only 3,300 transplants could be performed that year [2]. Despite the fact that the number of potential brain dead, i.e. heart-beating (HB), and realistic donors is estimated to be as high as $43-55$ per million population (p.m.p.) annually [3], the overall retrieval rate for 1996 within the ET area only was 14.5 p.m.p. This resulted in 27.3 kidneys p.m.p. available for transplantation. Obviously, more efforts are needed in effectuating potential HB donors through educating both lay public and health care providers. The persisting organ shortage, however, increases the need for alternative sources of donor organs.

Although transplantation with organs from living donors gives superior results when compared to cadaveric organ transplantation [4], the actual number of donors is limited and is unlikely ever to meet the demand. With non-heart-beating (NHB) donors, expansion of cadaveric organ donor programs is possible. In contrast to the HB donor that is declared dead after irreversible cessation of all brain sten functions, the NHB donor is declared dead after irreversible and final cardiac arrest. As a consequence, NHB donors have no circulation and immediately an ischemic state occurs, whereas patential HB donors remain ventilated and have a beating heart after the diagnosis of brain death. Therefore, in HB donation, organs can be recovered electively while they are sufficiently oxygenated and are not damaged by warm ischemia. The NHB donor is a still relatively underdeveloped source that can be very valuable in decreasing the discrepancy between demand and supply of transplantable kidneys [5,6].

Although the impression may exist that the concept of NHB donation is new, the concept is merely revitalised. In fact, before the notion of brainstem death was generally accepted, organ procurement was 
only possible from donors after final circulatory arrest [7], i.e, from NHB donors. These donors then were all patients with severe brain trauma from which ventilatory support was withdrawn in the operating room (OR). After apnoea and subsequent cardiac arrest, organs could be procured. Together with the introduction of criteria for brainsten death and the use of HB donors, the wse of NHB donors dechined; probably because it was thought that they provide an inferior quality of organs and that the use of ischemically damaged organs should be prevented. Additionally, in the early 1970 s the number of available HB donors was sufficient to meet the demand at that time. Because of the reduced organ recovery rates, nowadays there is renewed interest in NHB donors. Several emergency protocols for salvaging organs after final circulatory collapse and for keeping the option of organ donation, have been developed [8,9]. Since especially kidneys seem to tolerate ischemia well, almost exclusively kidneys may be procured following such protocols [10,11]. At the University Hospital Masstricht; a NHB donor program based on such an emergency procedure was implemented in 1980 and kidneys from NHB donors have been recovered and transplanted since [12].

\section{Non-Heart-Beating Donon's}

NHB donors have in common that they sustain irreversible cardiac arrest before organs are procured. Subsequently, the kidneys suffer an ischemic insult of unknown severity. This warm ischemia time (WIT), defined as the period from circulatory standstill until the start of organ cooling, is important for the viability and posttransplant function of the grafts. Essential in the NHB donor is to limit the WIT and establish cooling of organs as soon as possible after asystole in order to slow down metabolism and prevent organs from further decay. Because final cardiac arrest may occur under very different conditions, four categories of NHB donors have been defined; category 1 Dead on awrval, category 2 Unsuccessful resuscination, category 3 Awaiting cardiac arrest, and category 4 Cardiac arrest whila brain dead, respectively [13]. These categories are described in more detail in chapter 2.

\section{Cooling Techniques}

In NHB donation warm ischemic damage is the most detrimental factor to the organ and a major determinant of function after transplantation. Therefore, rapid cooling and flushout of blood from the organs as soon as possible after cessation of circulation, declaration of death, and obtaining consent, is essential for successful organ recovery in NHB donors. By decreasing the core temperature of the kidney to $15^{\circ} \mathrm{C}$, metabolism is decreased with $90 \%$, reflected by decreased oxygen consumption of tubular cells [14]. This is mainly because at this temperature the sodium-potassium pump, responsible for $85 \%$ of 
wbular oxygen consumption, ceases to function [15]. For realising this cooling, several techniques may be employed.

The most simple way is to start intra-aortal cooling after laparotony similar to HB donor procurement. Controlled NHB donor procedures (caregory 3) may take place in the OR and after withdrawal of vernthlatory support and subsequent cardiac arrest, immediate laparotomy is performed. Rapid recovery techniques of all abdominal organs are developed; initial cooling of organs through femoral catheters and subsequent back table cooling will preserve organs for transplantation $[16,17]$. In renal donors, in a controlled setting, kidneys can at first be procured without cooling and, after 15-18 min of WIT flushed at the back table irnmediately after procurement [18]. Under noncontrolled conditions (categories 1,2.4) rapid intra aortal cooling requires an emergency laparotomy which might cause logistic difficulties and problems in obtaining consent for donation, if needed [19].

Dewices, like the double-balloon-triple-lumen (DBTL) catheter [8], have been deweloped for rapid in-situ intravascular cooling. These catheters are placed in the common femoral artery, advanced into the aorta, and (after filling the balloons proximal and distal of the renal arteries) the kidneys can be flushed (fig. 1). Occasionally, introduction is impossible because of severe femoral atherosclerosis or size of the donor arteries. Experimental data revealed that a minimal perfusion pressure of $70 \mathrm{mmHg}$ is needed for rapid and successful in-situ cooling of the kidneys resulting in better survival and earlier function $[8,20]$.

Sometimes intravascular cooling has been combined with intraperitoneal cooling; although experimental data showed quicker cooling of the kidneys, no advantages of additional peritoneal cooling have been. reported in clinical transplantation $[21,22]$. Results on initial peritoneal cooling alone, before emergency laparotony and intravascular renal cooling, were reported by Orloff et al. 223], although in an near-tocontrolled setting.

Total body cooling as method of organ preservation after cardiac arrest has been reported by several authors [24,25] using a femoro-femoral bypass and extracorporeal perfusion devices [26]. These procedures, however, are rather complicated and technical problems have to be solved when used in uncontrolled NHB donor procedures.

Simplicity of procedures is important in the acceptance of donation procedures; health care workers will probably be more reluctant towards difficult and technically demanding procedures that need the availability of specially trained personnel and equipment. 
Figure 1. Schematic drawing of the DBTL catheter in a NHB donor.

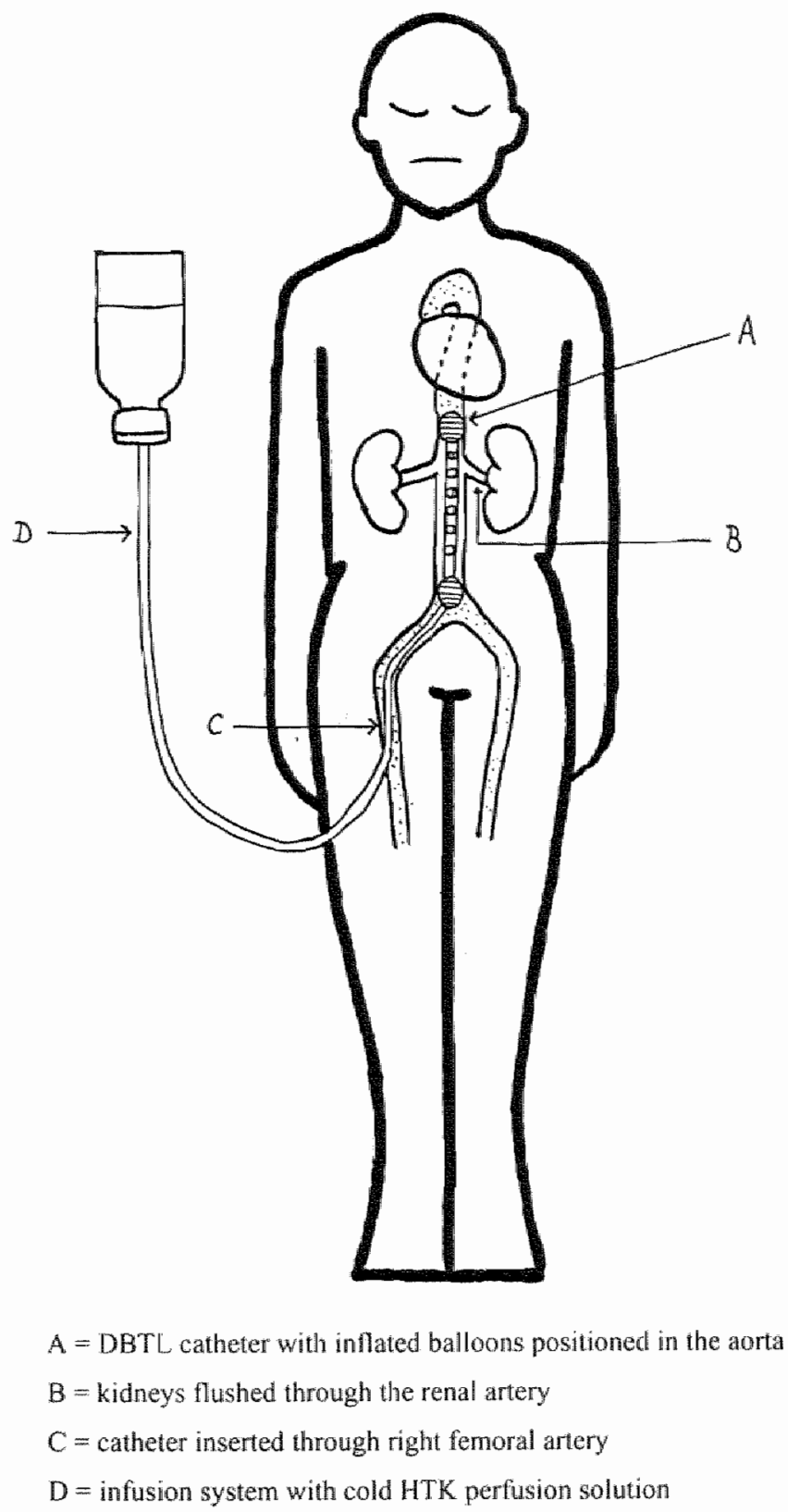


A way to bridge the time period betwen cardiac arrest and procurement of the kidneys, is by means of a mechanical cardiopulmonary resuscitation device. Successful organ preservation was reported by employment of this method for periods up to 4 h [27].

Instead of continuing to perfuse the organs with wam oxygenated blood, others have attempted to preserve organs by means of warm preservation solution. Tojimbara et all. [28] recently reported successful experimental preservation of ischemically damaged livers through initial flush out with warm University of Wisconsin (UW) cold storage (CS) solution. Also 6 h of ex vivo canine kidney preservation at temperatures of $25-32^{\circ} \mathrm{C}$ seemed feasible and resulted in successful autotransplantation [29]. This warm preservation method is based on a perfusate developed from a modified tissue culture medium and perfluorochemical enulsion as an oxygen carrier and it maintained renal metabolic function well. It also might be developed into an in-situ preservation technique in noncontrolled NHB donation procedures to bridge the period between cardiac artest and organ procurement. As a preservation method it was also proposed to enable functional evaluation of the kidneys prior to transplantation [ 30 ].

\section{Donor Criteria}

In our program, NHB donors are considered acceptable when the duration of initial cardiac arrest, i.e. time from cardiac arrest until start of adequate resuscitation, does not exceed $30 \mathrm{~min}$. Additionally, we accept a 2-hour resuscitation period (table 1). So, the totall WIT, i.e. time from initial cardiac arrest until. cooling of organs through an in-situ preservation (ISP) procedure can be established, may be 150 min maximum. Although no experimental data on the impact of resuscitation on perfusion of the kidneys are available, we assume that ongoing cardiac massage and ventilation are to be preferted over no support at all. Efficiency of cardiac massage and ventilation are checked by arterial blood gases.

At the University Hospital Maastricht, we consider 65 years the upper age limit for NHB donors. Other exclusion criteria are signs of sepsis or intravenous drug abuse, or a history of untreatable hypertension, kidney disease, and malignancies other than primary brain tumours. It is obvious that in some NHB donors, especially category $I$ and category 2 NHB donors, essential information about the patient's medical history may not be available until after the nephrectomy. Other programs may apply other criteria for age and ischemia times.

In the Maastricht recovery area with approximately 750,000 inhabitants, kidneys are recovered from NHB donors according to these criteria. In the period 1980-1992, kidney retrieval from 67 NHB donors 
resulted in 79 transplants (59\%); in the same period 346 kidneys were ransplanted from 183 HB donors $(95 \%)$. Thus NHB donors accounted for $18 \%$ of the total number of kidneys transplanted; in 1994, NHB donation even accounted for $40 \%$ of the total number of kidneys available for transplantation in our area [31]. Of course, relatively more kidneys from NHB donors are discarded for reasons of damage, bad insitu or back table fush-out. Some kidneys were not transplanted because no suitable recipient was available ( $\mathrm{AB}$ blood type, $\mathrm{HCV}$ positive donor). Others reported a similar increase in kidney procurement rates after implementing a NHB donor program [32].

Table 1. NHB donor criteria

* Time between cardiac arrest and start cardiopulmonary resuscitation $<30$ min

* Effective cardiopulmonary resuscitation $<2$ h

* Age $\leq 65$ years.

* No signs of systemic infection or sepsis

* No signs of intravenous drug abuse

* No patient history of: - untreatable hypertension

- kidney disease

- malignancies other than primary brain tumours

\section{NHIB Donor Procedure}

In the Maastricht program $75 \%$ of the potential NHB donors are reported from the ER, i.e. in an uncontrolled setting (category 2). After the team of physicians taking care of the patiant and performing cardiopulmonary resuscitation has declared this patient dead on cardiac criteria, potential NHB donors are reported to the transplant co-ordinator. After accepting the donor as medically suitable the transplant team is notified and the relatives are approached for obtaining consent. Meanwhile, cardiac massage and antificial ventilation are resumed after a waiting period of $10 \mathrm{~min}$. This period is introduced to respect the dead donor rule [33] and to make it clear to anyone inwolved that there is a change from satving a patient's life to salvaging organs for donation. To optimise renal perfusion, heparin $(20,000$ lU) and phentolamine $(0.125 \mathrm{mg} / \mathrm{kg})$ are administered intravenously and flushed with saline. Al consent, an arteriotomy is performed through a longitudinal incision ower the inguinal ligament and a $\mathrm{Ch} / 6 \mathrm{DBTL}$ 
catheter (AJ 6516. Porges, Le Pessis-Robinson, France)(fig. 2) is insented. Through the common femoral artery the DBTL catleter is positioned in the aorta and ISP of the kidneys is started. As fush-out solution we use large wolumes, approximately $10-15$ litres are neded, of cold histidine-tryptophan-ketoglutarate (HTK, Bretschneider solution) [34]. The advantage of HTK is thought to be the strong buffer capacities at temperatures $>10^{\circ} \mathrm{C}$ through the histidine-HCl buffer [35], and is is avallable in 5-liter bags. The initial flush-out is done from a height of $100 \mathrm{~cm}$ or by means of a roller pump to obtain the minimally required pertusion pressure. By filling the balloons with a radiopaque solution, the position of the DBTL catheter can be checked by abdominal X-ray (fig. 3) and adjusted if necessary.

Figure 2. DBTL cooling catheter with inflated balloons.

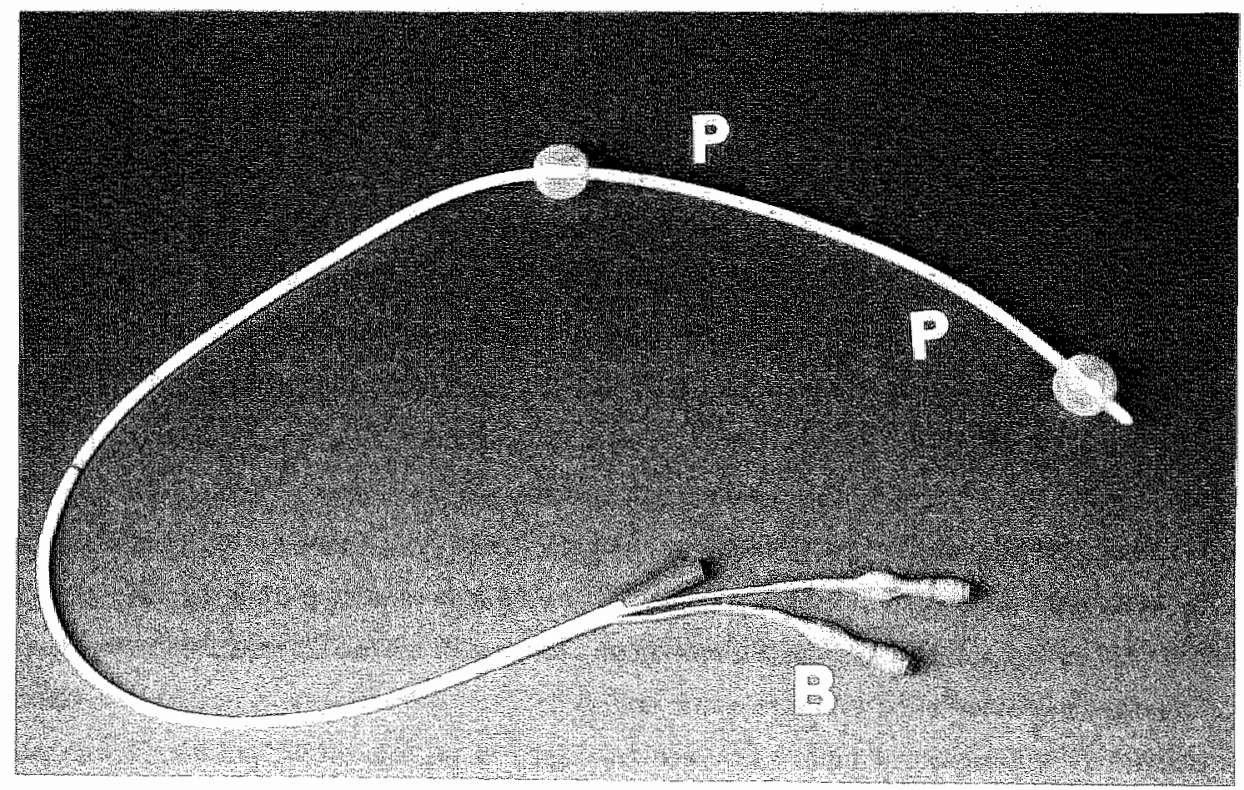

Distance between the balloon is $23 \mathrm{~cm}$. with multiple double-sided perforations (P) for easy and rapid perfusion. Rupture of balloons may be recognised through the small control balloons (B). 
Figure 3. Abdominal radiograph of a DBTL catheter in situ.
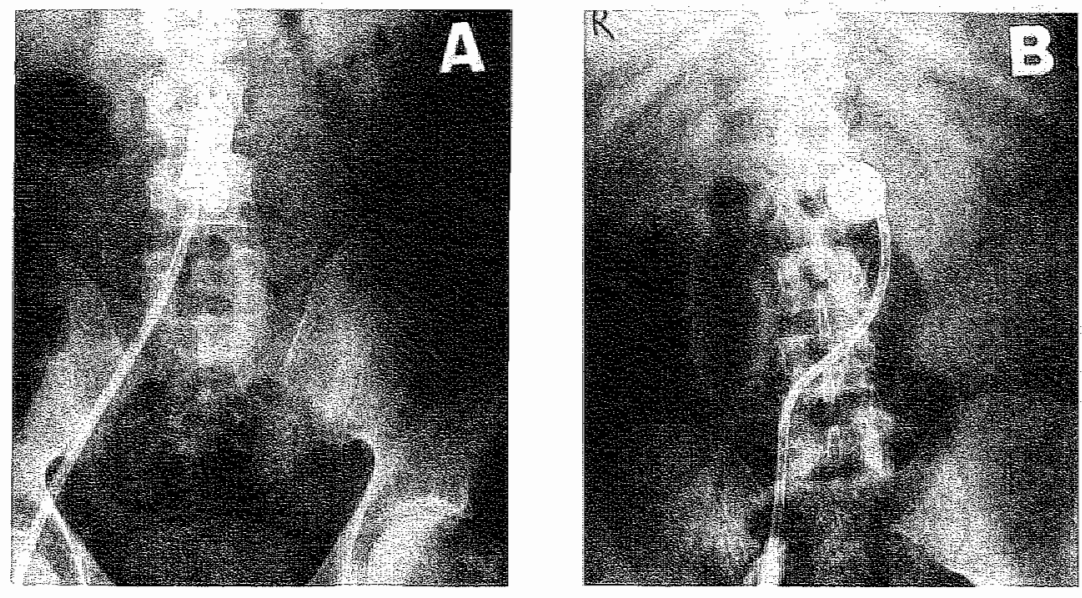

(A) The catheter is inserted through the right fenorai artery and is placed cortectly. Note the elongated and ypical. contour of the abdominal balloon sfuck at the aortic bifurcation; the thoracic balloon cannot be seen.

(B) The catheter is insented through the right femoral artery; the abdominal balloon is in an incorrect position in the right iliac artery while the thoracic balloon shows an atypical position. The donor was supposed to have died of myocand anl infarction but appeared to have an aneurysm of the distal aorta as well. This explains the alypical position of the DBTL cathefer.

Venous drainage is secured by a simple Ch22 urinary catheter inserted into the fomoral vein. An important part of our procedure is that belore nephrectomy, it is arranged for relatives and/or a priest to visit the deceased. The nephrectomy is performed preferably as soon as possible after starting the in situ cooling; however, procedures have been successful with in situ cooling for up to four hours [8,36]. Nearto-conirolled NHB donor procedures (category 3) are performed at the Intensiwe Care Unit (ICU) 
following the surne procedure using DBTL catheter and ISP. This in contrast to the controlled NHB donation procedures in an OR after withdrawal of ventiatory support and subsequent cardiac arrest; in some protocols laparotomy and cooling is started just $2-4$ min after cardiac arrest $[18,37]$.

\section{Preservation}

Simple CS is widely accepted as the method of choice for the preservation of renal grafts since it is cheap and easy. The advantages of preservation by continuous cold perfusion are most pronounced for prolonged presterwation times [38] and kidneys from marginal donors with ischemical damage [39]. Recent experimental work at ou center showed that preservation of ischemically damaged kidneys by machine perfusion (MP) was superior to preservation by CS with HTK solution [40]. MP resulted in better survival rates and bether preservation of the microcirculatory integrity [41]. Kozaki et al. [42] and Matsuno et al. [43] confirmed these results in a clinical transplant program using NHB donors from which one kidney was preserved by MP and the contralateral by CS. All machine perfused NHB donor kidneys had earlier life-sustaining function than the contralateral renal grafis preserved by $\mathrm{CS}$. D'Alessandro et al. [18] and Orloff et al. [23] achieved impressive results transplanting NHB donor kidneys after preservation by MP. Another advantage of MP is that it allows access to the kidneys for intervention and the possibility of evaluating the condition of the grafts [44].

Recently a new preservation method for NHB donor kidneys has been proposed, using MP with a feedback mechanism resulting in adequate perfusion pressure at much lower flow rates [45]. This is thought to reduce the additional vascular preservation damage by continuous perfusion. Clinical application of this MP method needs to be evaluated.

Another method to preserve ischenically dmaged kidneys is the use of retrograde persuflation of oxygen through the renal vein. In animal cxperiments it was shown that the resynthesis of high energy phosphates was improved; survival rates, however, could not be increased [46-48]. Although experimental datt were promising, so far no evident clinical improvement of transplant results has been reported [49]. Successfull experimental preserwation of ischemically damaged extrarenal organs has been reported; liver and pancreas metabolism could successfully be resuscitated using respectively, normothermic perfusion and wo-layer (UW/perfluorochemical) hypothermic storage methods [50,51].

In 1993 we re-introduced MP as the preservation method of choice for our NHB donor kidneys, with the intention to reduce the delayed function (DF) rates. After the ISP procedure and subsequent 
nephrectomy, the kidneys are prepared on the back table and the renal antery is onnulated for MP. Routhely cortical wedge biopsies atre taken for histological examination. Then the kidney is placed in a specially designed organ chanber (fig. 4) fitting into a Gambro-PF-3B perfision machine (hg. 5 ).

Figure 4. Organ chamber with a human donor kidney eannulated and connected to the perfusion systiem.

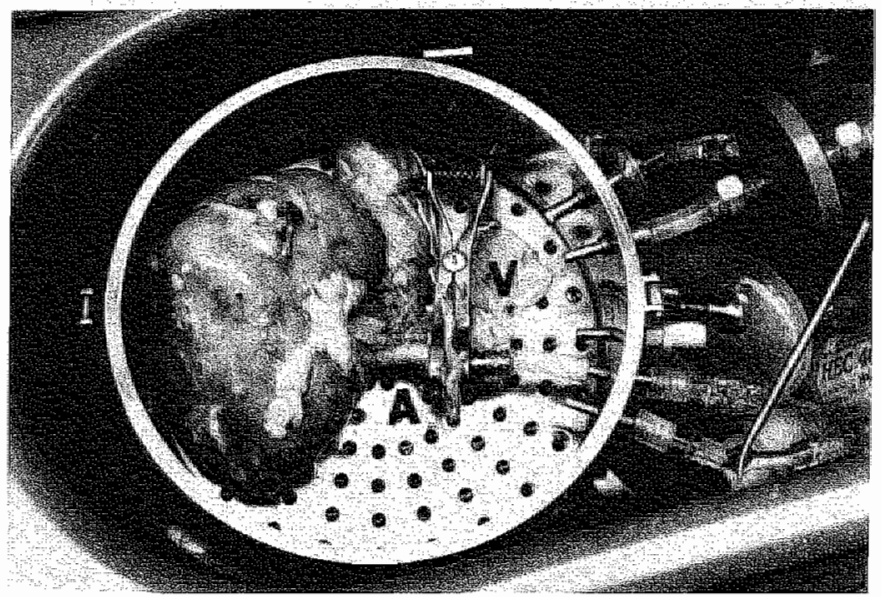

The renal artery (A) is connected to the perfision system by a bull-dog clamp. The afluent from the renal vein (V) tlows freely into a container at the bottom of the organ chamber and from there re-enters the perfusion circuit.

As a perfusate we use Belzer's perfusate, the UW solution developed for perfusion preservation. It. is based on the UW CS solution (Viaspan), basically with the impermeant gluconate replating the lactobionate [38]. In UW solution for MP the serum albumin as a colloid has been replaced by the toially synthetic hydroxy-ethyl-starch (HES) [52]. With albumin based perfusates human blood products are needed (human albumin in either plasma, protein plasma fraction, silica gel fraction or human albumin added to saline or Ringer's lactale) with all the specific risks of these blood producis. Additionally, albumin has a limited use as intravascular oncotic pressure diminishes in the course of preservation [53]. it is known to cause endothelial damage [54], and last but not least, plasma is known to predispose for rejection [55]. The synthetic Belzer's perfusate eliminated all these side effects of plasma derived 
products and proved to reduce rates of acute tubular necrosis (ATN)[56].

Figure 5. Organ chamber placed in a Gambro-PF-3B organ perfusion machine.

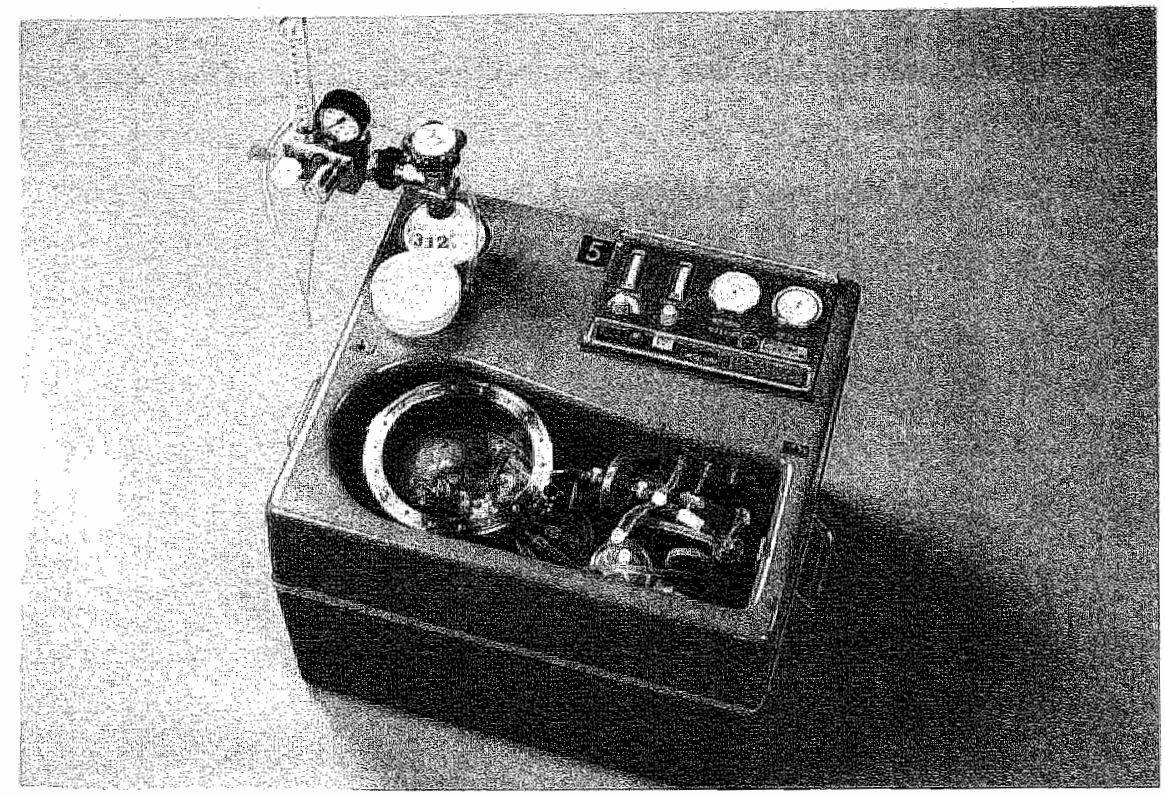

After connecting the kidney to the perfusion system, perfusion flow is set to a systollic pressure of 60 mmHg and kept constant. The pressure is subsequently allowed to wary as an indicator of intrarenat vascular resistance (IRR). When IRR fails to decrease, accompanied by high lactate dehydrogenase release in the perfusate and tow pH, the kidneys are nol used for tansplantation [44]. When donor history reveals no contraindications, histology shows no shgns of renal cortical necrosis or severe pre-existent renal damage, and the kidneys do well during continuous perfusion, we consider the kidney suitable for transplantation. The kidneys are finally transported to the tramsplant center selected by Eurotransplant and remain in the perfusion machine until implantation. 


\section{Transplant Results}

Although nowadays some programs are procuring extrarenal organs from NHB donors (mantly coregory 3 NHB donors), most centers have only experience with kidneys from NHB donors. Reports on transplant outcome show in general high rates of DF", most likely due to ATN (table 2), Early reports showed no difference in short term transplant outcome between controlled NHB and HB donor kidneys. with DF rates of $40 \%$ and $3.1 \%$ [58,59]. More recently when transplanting NFB doror kidneys, DF rates were found to vary from 60 to $90 \%[43,60-65]$, although from the University of Rochester a DF rate of not higher than $22 \%$ was reported [23]. The long-lasting program at the University of Wisconsin reported similar results [18].

Table 2. Transplantation results with kidneys from NHB donors

\begin{tabular}{|l|c|c|c|}
\hline Center $^{1}$ & NHB donor category & DF rate $^{3}$ & 1-yr graftpatient survival $^{4}$ \\
\hline Barcelona (E) [62] & 3,4 & 67 & $90 / 92$ \\
\hline Leicester (UK) [64] & 2 & 90 & $93 / ?$ \\
\hline Zurich (SUR) [63] & 2,3 & 29 & $84 / 90$ \\
\hline Madison (USA)[18] & 3 & 19 & $83 / 94$ \\
\hline Pittsburgh (USA) [15] & 2,3 & 69 & $85 / 95$ \\
\hline Maastricht (NL) [59] & $2,3,4$ & 65 & $73 / 95$ \\
\hline
\end{tabular}

$1=$ See reference list.

$2=$ Category of NHB donors; description see text and reference 13

$3=$ Delayed function; reported DF rate $(\%)$.

$4=$ Reported 1 -year graft $(\%)$ and patient survival $(\%)$ 
However, all these procedures were in a near-10-controlled setting (category 3 NHB donoss) with WT of 20-35 min and very restrictwe criteria for potential donors. Remarkably, boh programs prefer MP as method of preservation tor their NHB donor kidneys. Long-tem graft and patient survival were reported to be equal for NHB and HB donors from almost all programs $[19,24,25,32,61,66,67]$. Only one program reported awidently lower l-year graft survival. No cardiac massage, articial ventilation, or in-situ. cooling was applied in this program and all donors were NHB donors who suffered about 45 min of WIT after an agonal pertod in a nearby hospice [68]. Remarkable results were reported by Naqui et al. [69], with two kidneys from $\mathrm{NHB}$ donors that addihonally suffered extreme long cold ischemia times.

Transplantation results of all kidneys from NHB donors procured in the period from 1980 to 1992 at the University Hospital Maasticht and transplanted within the ET area, were recently analysed [60]. Transplant outcome of NHB donors ( $n=57$ ) was compared to a matched FB control group ( $\mathrm{n}=1$ 14). Most NHB donors were from category 2 and occasionaly category 3 or 4 and none of the NHB donor procedures took place under controlled circumstances in the OR. Apart from the cause of death, donor data in these series were comparable. Short-term results showed almost twice as much DF (i.e., need for postransplant dialysis) in the NHB group. Kidney function was equal for both groups within 3 months postransplant; graft and patient survival were not different for up to 10 years.

Transplant results of extranenal organs, including liver, pancreas and lumg, are excellent and equal those obtained in HB donation as long as the procedure is performed under controlled conditions with minimal warm ischemia (category 3) [14,15]. Liver transplants in noncontrolled situations resulted in primary nonfunction (PNF) in half of the cases [62].

It is obvious that the circumstances under which donors sustain irreversible cardiac arrest, as well as the duration of the warm ischemic period (i.e. the respective NHB donor cattegory), have a major impact on tramsplant outcome. The excellent results from Zurich [64], for instance, are achieved with kidneys from NHB donors, who are mainly trauma victims that die in the OR and whereof the kidneys are used as prinary transplants only. The repons from Madison [14,18], Rochester [23], and Pittsburgh [15] are based on NHB donors who have died after withdrawal of life-sustaining treatment and therefore resulting in extreme shor warm ischemic limes. The resulls from Leicester, on the contrary, are only with grafts from donors after resuscitation in a uncontrolled setting [32].

In generall though, transplant results with renal grafts from NHB donors are good and comparable to results with HB donor grafs, although with significantly increased DF rates. Particularly in category 2 
NHB donors with long resuscitation efforts and subsequent prolonged WIT, organs nay be profoundly damaged by warn ischemia and give PNF upon transplantation. Obviously, PNF and viabilty of the kidneys are of major concem in uncontrolled NHB donation. Parameters that indicate the ischemic damage sustained and that may predict functional outcome of the NHB donor kidneys upon grafting, will help to prevent the transplantation of organs that are not viable. Although sevaral potentially useful parameters have been proposed, none of them are routinely used for assessment of organ viability in clinical practice [71-75]. This subject is addressed in chapters 6 and 7 .

\section{Ethical Issues}

As stated before, transplant medicine started with results obtained through the use of NHB donors sustaining cardiac arrest after withdrawal of mechanical ventilation. Without this pioneering, transphant results could not have made the same progress as they did later on. As discussed by Youngnet et al. [75], the reluctance towards NHB donation may be bised upon the fact that there is controversy whether two basic requirements for organ donation are med [76]. Firstly, there is the dead-donor rale: ongans should be taken only after death and patients should not be killed by organ venowal 33 ]. In case of calegory 3 NHB donation procurement procedures are started after cardiac arrest has occurred. Although in some protocols organ cooling is already prepared before withdrawal of support, laparotony with subsequent. organ removal is started after $2-4$ min of asystole $[16,17]$. it is disputable whether after this short period without circulation all brain functions have ceased. In favour of these procedures is the fact that it is the wish of the deceased or the relatives to withdraw life-sustaining treatment, because of incurable discase, and to donate organs. Within our NHB donor program at the University Hospital Maastricht in case of category 3 NHB domation, ventilation is withdrawn at the ICU and cardiac arrest is often witnessed by the next of kin. A waiting period of 10 min of asystole is respected to ascerlain that there is a neurological state comparable to brain death before starting the ISP procedure. It is very unltkely diat from these donors extrarenal organs can be procured and successfully transplanted since with these organs immediate posttransplant function is necessary. In category 2 NHB donaron, paticnts are declared dead after unsuccessful cardiopulmonary resuscitation and may subsequently become NHB organ donors. Although the patient already is declared dead by the attending physician, according to our

protocol, again the 10 min waiting period is respected, before the transplantation team takes over and restarts cardiac massage and artificial ventilation. No doubt there is a neurological state comparable io brain death. Furthermore, a separation of procedures directed towards saving patients or preserving organs is secured. Criteria for declaring patients dead under such circumstances in order to have the option of organ donation have recently been defined by the Swiss Academy of Medical Sciences [77]. 
They state that cardiac arresi is irreversible, whenever despite full mechanical and chemical resuscitation efforts for 30 min, there is no restoration of spontaneus circulation. In case of deep coma together with apnoed and pulselessmess, the patient may be declared dead and organ procurement may follow. In countries with the legal system of presumed-consent or with systems that allow introduction of cooling catheters before consent, organs can be preserved immediately until consent for organ donation is obtained. In our program after the 10 min waiting period, cardiac massage and mechanical ventilation are resumed until organ donation thas been discussed with the relatives; sometimes initially only consent for introduction of the DBTL catheter for ISP is obtained while maintaining the option of donation [78].

The second basis of organ donation is that care of living patients cannot be compromised in fovor of potential recipients. With regard to this rule, a strict separation is needed of physicians taking care of patients and physicians directly involved in transplantation. "Wherefore, death must be diagnosed by someone not involved in the transplantation process. This separation is not always possible as patients. will be idtentified as potential category 3 NHB donors by the attending physician who, as in HB donation, will often discuss organ donation with the relatives before death of the donor. Evaluation by external reviewers whether all steps are according to the protocol for NHB donation on a case-to-case basis may minimise the chance of a conflict of interests [80]. In case of caregory 2 NHB donation, the decision to stop resuscitation and proceed towards organ donation may be reviewed by such a committee in retrospect.

We feel that reluctance about NHB donation results from unacquaintedness with the procedure and therefore education and openness towards public and medical health care professionals are mandatory. Additionally, NHB donor programs should only be implemented based on written protocols approved by the local ethics committee. Recently, at the First International Workshop on NHB Donors, statements and recommendations on this subject have been postulated [80].

\section{References}

1. Terasaki PI, Yuge J, Cecka JM, Gjertson DW, Takemoto S, Cho Y. Thirty-year trends in clinical kidney Iransplantation, in: Terasaki P, Cecka JM (eds): Clinical Transplants 1993. Los Angeles, UCLA Tissue Typing Laboratory, 1994, pp 553-562

2. DeMeester J. Eurotransplant: donation, waiting lists and transplarnts, in: Coher B, Persijn G, DeMeester J (eds): Eurottansplant International Foundation: Anmuall Report 1996. The Hague, Koninklijke Bibliotheck, 1997, pp 23-32

3. Evans RW. The actual and potential supply of organ donors in the Unied States, in: Terasaki PI, Cecka 
JM (eds): Clinical Transplants 1990. Los Angelss, UCLA Tissus Typing Labmatory, 199. 19p 329-341

4. DAlessandro AM, Sollinger HW, Knechtle SJ, Kalayoglu M, Kisken WA, Uehling DT, Mon TD, Messing EM, Bruskewitz RC. Pirsch JD. Belzer FO. Living related and unrelated donow for kidney transplantation: A 28-year experience. Ann Surg 1995; 222: 353-364

5. Kootstra $G$, Wijnen RMH, van Hooff JP. CJ van der Linden. Twenty percent more kidneys through in non* heart-beating donor program. Transplant Proc 1991:23:910-911

6. Nathan HM. How many organs would be made available by organ procurenem from non-heart-beating donors? 26ht International Conference on Transplantation and Clinical Inmunology, Lyon, France, June $13-15,1994$

7. Belzer FO, Kountz SL. Preservation and transplantation of human cadawer kidneys: A two-yeur experience. Arn Surg 1970; 172: 394404

8. Anase D, Smith R, Ishimant $M_{0}$ Waltzer WC, Shabtai M, Hurfey S, Rapaport FT. An appronch to organ salvage from non-heartbeating cadaver donors under existing legal and ethical requirements for transplantation. Transplantation 1990; 49: 290-294

9. Garcia-Rinald R, Lefrak EA, Defore WW, Feldman L, Noon GP, Jachinczyk JA, DeBakey ME. In situ preservation of cadaver kidneys for transplantation: Laboratory observations and clinical application. Arin Surg $1975 ; 182: 576-584$

10. Maessen JG, van der Vusse GJ, Vork M, Kootstra G. The stunned kidney: Postischemic renal failure and adenine rucleotide homeostasis, in: Maessen JG (ed): Evaluation of Isethemic Injury in Donor Kidneys: An experimental Study. Helmond, Wibro dissertatie drukkerij, 1988, pp $81-88$

1. R. Rigotti $P$, Morpurgo E, Comandella MG, Pittoni G, Ganz E, Piazza L, Capalbo M, Valente ML, Ancona E. Non-heart-beating donors: An altemative source in kidney transplantation. Transplant Proe $1991 ; 23$; $2579-2580$

12. Vroemen JPAM, wan der Vliet JA, Kootstra $G$. The emergency in situ preservation of kidneys for transplantation. Neth J Surg 1983; 35: 55-60

13. Kootstra G, Daemen JHC, Oomen APA. Categories of non-heart-beating donors. Transplant Proc 1995; 27. $2893-2894$

14. Levi MN. Influence of variations in blood flow and diwitrophenol on renal oxygen consumption. Am J Physiol 1959: 196: 937-942

15. Hochachka PW. Defense strategies against hypoxia and hypothermia. Science 1986;231:234-241

16. D'Alessandro AM, Hoffmann RM, Knechtle SI, Ecklioff DE, Love RB, Kalayoglu M, Sollinger HW, Belzer Fo. Successful extrarenal iransplantation from non-heart-beating donors. Transplantation 1995; $59: 977-982$

17. Casavilla A, Ramirez C, Shapiro R, Nghiem D, Miracle K., Bronsther O, Randhawa P, Broznick B, Fung J, Starzl TE. Experience with liver and kidney allografts from non-heart-beating donors. Transplantation $1995 ; 59: 197-203$

18. D'Alessandro AM. Hoffmann RM, Belzer RM. Non-hneart-beating donors: One response to the orgen shortage. Transplant Rev1995; 9: 168-176 
19. Schlumpf $R$, Candinas $D$, Zollinger $A$, Keasch $G$. Retsch $M$, Decurtins $M$, Largiader $F$. Kidney prowument from non-heart-beating donors: Transplantation results. Transpl Int 1992; 5 (suppl):424-428

20. Anaise D, Yland MJ, Waltzer WC, Frischer $Z_{*}$ Hurley $S$, Eychmulter $S$, Rapaport FT. Flush pressure requirements for optimal cadaverie donor kidney preservation. Transplant Proc 1988; 20:8911-894

21. Matsuno N, Kozaki M, Sakurai E, Uohiyama M, Iwakori T, Kozaki K, Kono K. Tanaka M, Tamaki T, Tumalki ll. Effect of combination in situ cooling and machine perfusion preservation on non-heart beating donor kidney procurement. Transplant Proc 1993:25:1516-1517

22. Anaise D, Yhand MJ, Ishman $M$, Shabai M, Hurley S, Waltzer WC, Rapaport FT. Organ procurement from non-heart-beating donors. Transplant Proc 1989:21:121!-121.4

23. Orloff MS, Reed AL, Erturk E, Kruk RA, Paprocki SA, Cimbalo SC, Cerilli GI. Nonheartbeating cadaveric organ donation. Ann Surg 1994; 220:578-585

24. Valero R, Manalich M, Cabrer $C$, Salvador $\mathbb{H}_{\text {, }}$ Garciam Fages LC. Organ procurement from non-hearibeating donors by total body cooling. Transplant Proc 1993; 25: 3091-3092

25. Castelao AM, Grino JM, Gonzalez C, Franco E, Gil-Wernet, $S$, Andres E, Seron D, Torras I, Moreso F, Alsina J. Update of our experience in long-term renal function of kidneys transplanted from non-heartbeating cadaver donors. Transplant Proc 1993; 25: 1513-1515

26. Gomez M, Alvarez J, Arias J, Barrio R, Balibrea JL, Mattin F. Cardiopulnonary bypass and profound hypothermia as means for obtaining kidney grafts from irreversible cardiac arrest donors: Cooling technique. Transplant Proc 1993; 25: $1501-11502$

27. Szostek M, Danielewicz R, Lagiewska $\mathbb{B}$, Pacholezyk M, Rybicki Z, Michalak G, Adadynski L, Walaszewski $J$, Rowinski W. Successful transplantation of kidneys harvested from cadaver donors at 71 to 259 minutes following cardiac arrest. Transplatat Proc 1995; 27: 2901-2902

28. Tojimbara T, Kennedy RG, Burns W, Hayashi M, Krams S, Martinez O, So S, Esquivel CO. The use of non-heart-beating cadaver donors in experimental liver transplantation. Transplantation 1995; 60: 11791180

29. Brasile $\mathrm{L}_{*}$ Clarke \&, Green $\mathrm{E}$, Haisch $\mathrm{C}$. The feasibility of organ preservation at warmer temperatures. Transplant Proe 1996:28: $349-351$

30. Hasch $C_{i}$ Thomas $F$, Green $E$, Brasile $L$. Evaluating renal allograft function prospectively. Transplant Proc 1996; 28: $363-364$

31. Daemen JMC, de Wit RU, Bronkhorst MWGA, Yin M Heineman E Kootstra G. Non-heart-beating donor program contributes $40 \%$ of kidneys for transplantration. Transplant Proc 1996; 28: $105-106$

32. Varty K, Veitch PS, Morgen JDT, Bell PRF, Kidney tetneval from asystolic donors: A valuable and viable resource of additional organs. Br Med J 1994; 1:1459-1460

33. Arnold RM, Youngner SJ. The dead donor rule: should we bend it, stretch it, or abandon it? in: Arnold RM, Youngner SI, Schapiro R, Spicer CM (eds): Procuring Ongans for Transplant: The Debate over NonHeart-Beating Cadaver Protocols. Baltimore, Johns Hopkins University Press, 1995, pp $219-234$

34. Isemer F-E, Ludwig A. Schunck O, Bretschneider H-J, Peiper H-J. Kidney procurement with the solution of Bretschneider. Transplant Proe 1988:20: $885-886$ 
35. Kallerhoff $M$, Hoelscher $M$, Ketuer $G$, Klaess $G$, Brefschneider HJ. Effects of preswrvation conditions and temperature on tissue acidification in canine kidneys: Transplantation 1985; $39: 485.489$

36. Booster MH, Winen RMH, Vroemen JPAM, var Hooff JP, Kootstra $\mathrm{G}$. In situ preservation of kidneys from non-heart-beating donors: A proposal for a standardized protocol. Transplantation 1993; 56: 613-61.7

37. DeVita MA, Snyder JV. Development of the University of Pittsburgh Medical Center policy for the care of terminally ill patients who may becone organ donors after death following the removal of life support, in: Amold RM, Youngner SJ, Schapiro R, Spicer CM (eds); Procuring Organs for Transplant: The Debete over Non-Heart-Beating Cadawer Protocols. Baltimore, Johns Hopkins Universily Press, 1995, pp 55-67

38. McAnulty JF, Ploeg R, Southard JH, Belzer FO. Successful five-day perfusion preservation of the canine kidney. Transplantalion 1989; 47: 37-41

39. Johnson RWG, Anderson M, Morley AR, Taylor RMR, Swinney J. Twenty-four-thour preservation of kidneys injured by prolonged warm ischemia. Transplantation $1972 ; 13: 174-179$

40. Bonster $\mathrm{MH}_{3}$ Wijnen RMH, Yin M, Tiebosch ATM, Heineman E, Maessen JG, Buurman WA, Kurvers HA.JM, Stubenitsky BM, Bonke $H_{*}$ Kootstra $G$. Enhanced resistance to the effects of nomnothermic ischemia in using pulsatile machine perfusion. Transplant Proc 1993; 25: 3006-3011

4l. Booster MH, Yin M, Stubenitsky BM, Kemering GJ, van Kroonenburgh MJPG, Heidendal GAK, Halders SGEA, Heineman E, Bumman WA, Wijnen RMH, Tiebosch ATM, Bonke H, Kootstra G. Beneficial effect of machine perfusion on the preservation of renal microcirculatory integrity of ischemically clamaged kidneys. Transplant Proc 1993; 25:3012-3016

42. Kozaki M, Matsuno N, Tamaki T, Tanaka M, Kono K, Ito H, Uchiyama M, Tamaki I, Sakurai E. Procurement of kidney grafts from non-heart-beating donors. Transplant Proc 1991; 23: 2575-2578

43. Matsuno N, Sakurai E, Tamaki I, Uchiyama M, Kozaki K, Kozaki M. The effect of machine perfusion preservation versus cold storage on the function of kidneys from non-heart-beating donors. Transplantation 1994; 57: 293-294

44. Daemen JHC, Heineman E, Kootstra G. Viability assessment of non-heart-beating donor kidneys during machine preservation. Transplant Proc 1995: 27: 2906-2908

45. Yland MJ, Anaise D, ishimaru M, Rapaport FT. New pulsatile pertusion method for non-heart-beating cadaveric donor organs: A preliminary report. Transplant Proc 1994; 25: 3087 3090

46. Fischer JH, Czerniak A, Hauer U, Isselhard W. A new simple method for optimal storage of ischemically damaged kidneys. "Iransplantation 1978; 25:43-49

47. Minor $T$, lsselhard W. Synthesis of high energy phosphates during cold ischemic rat liver preservation with gaseous oxygen insufflation. Transplantation 1996;61:20.22

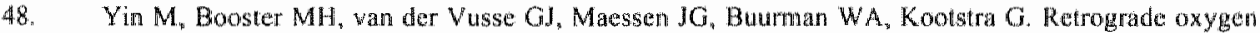
persuffation with UW solution enhances adenine nucleotide contents in ischemically daunaged rat kidney during cold storage. Transplant Int 1996; 9: 396-402

49. Rolles $K_{3}$ Foreman $J$, Pegg DE. A pilot clinical study of retrograde oxygen persulflation in renal preservation. Transplantation 1989;48: 339-342

50. Schön MR, Hunt Cl, Pegg DE, Wight DG. The possibility of resuscitating livers after warm ischemic 
injury. Transplantation $1993 ; 56: 24-31$

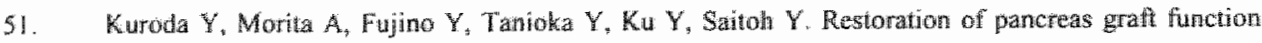
preserved by a two-layer (Uniwersity of Wisconsin solution/ perfluorochemical) cold storage method after significant warm ischemia. Transplantation 1993; $55: 227-228$

52. Belzer $\mathrm{FO}$, Glass NR, Solinger $\mathrm{HW}$, Hoffman RM, Southard JH. A new perfusate for kidney preserwation. Transplantation $1982 ; 33: 322-323$

53. Hofmann RM, southard $\mathrm{MH}_{3}$ Belzer FO. The use of oncotic support agents in perfusion preservation, in: Pegg DE, Jacobsen JA, Halasz NA (eds): Organ Preservation; Basic and Applied Aspects. Lancaster, MTP Press, 1982, pp 261-265

54. Southard JH, Senzig KA, Hoffmann RM, Belzer FO. Denaturation of the albumin; A critical factor in long-term kidney preservation. J Surg Res 1981; 30: 80-85

55. Clark EA, Terasaki PI, Opelz G, Mickey MR. Cadawer-kidney transplant failures ati one month. New Eng J Med 1974: 291: 1099.1102.

56. Barber WH, Laskow DA, Deierhoi MH, Poplawski SC, Diethel m AG. Comparison of simple bypothermic storage, pulsatile perfugion with Belzer's gluconate-albumin solution, and pulsatile perfusion with UW solution for renal allograft preserwation. Transplant Proc 1991; 23: 2394-2395

57. Daemen JHC, de Wit RU, Bronkhorst MWGA, Marcar ML, Yin M, Heineman E, Kootstra G. Short-term outcome of kidney transplanis non-heart-beating donors after preservation by machine perfusion. Transplant Int 1996; 9 (suppl): $76-80$

58. Didlake RH, Raju S, Smith GV, Krueger RP, Kirchner KA. Utilization and function of kidneys obtained from nonheartbeating donors. Transplantation 1984; 38:90-92

59. Schweizer RT, Sytphin BA, Bartus SA. In situ cadaver kidryey perfusion: Experimental and climical studies. Transplantation $1981: 32: 482-484$

60. Wijnen RMH, Booster MH, Stubenitsky BM, de Boer J, Heineman E, Kootstra G. Outcome of transplaniation of non-heart-beating donor kidneys. Lancet 1995; 345: 1067-1070

61. Hoshinaga K, Fujita T, Naide Y, Akutstu H, Sasaki H, Tsukiashi Y, Nishiyama N, Yanaoka M, Shinoda M, Kanno T. Early prognosis of 263 renal allografts harvested from nom-heart-beating cadavers using in situ cooling technique. Transplant Proe 1995; 27: $703-706$

62. Casavilla A, Ramirez C. Shapiro R, Nghiem D, Miracle K, Fung J, Starzl TE. Experience with liver and kidney allografts from non heart-beating domors. Transplant Proc 1995; 27:2898

63. Gonzatez C, Castelno A M, Torras J, Gilvemet S, Lopez MA, Riera L, Franco E, Fulladosa X, Grino dM. Alsina J. Long-term follow up of transplanted non-heart-beating donor kidneys. Transplant Proc 1995; 27: $2948-2950$

64. Schimpf R, Weber $\mathrm{M}$, Weinreich $\mathrm{T}$, Klotz $\mathrm{H}$, Zollinger $\mathrm{A}_{4}$ Candinas D. Transplantation of kidneys from mon-heart-beating donors: An update. Transphant Proc 1995; 27: 2942-2944

65. Dunlop P, Varty K, Veitch PS, Nicholson ML, Bell PRF. Non-hestt-beating donors: The Leicester experience. Transplant roc 1995; 27: 2940-2941

66. Vromen MAM, Leunissen KML, Petsijn GG, Kootstra G. Short- and long-lerm results with adult non- 
heart beating donor kidneys. Transplant Proc 1988: 20:743.745

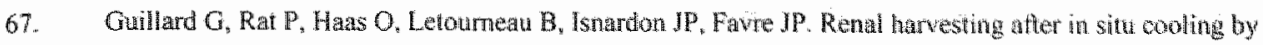
intra-aortic double-ballow caheter. Transplant Proc 1993; 25: 1505-1506

68. Phillips AO, Snowden SA, Hillis AN, Bewick M. Renal gratts from non-lkear beating donors. Br Med $1994 ; 308: 575-576$

69. Naqvi A, Zafar N washmi A, Akhan F, Hussain Z, Rizvi A. Two cadaverio renal transplents in Pakistan from non-heart-beating donors from Maastricht. Lancet 1996: 347:477-478

70. Buhl MR, Kemp G, Kemp E. Hypoxanthine excretion during preserwation of rabbit kidneys for transplantation: Ar assessment of the ischaemic damage. Transplantation 1976;21:460-467

71. Maessen JG, wan der Vusse GJ, Vork M, Coumans WA, Kootstra G. Determination of warm ischemia time at donor nephrectomy. Transplantation 1988:45:147-152

72. Bretan PN, Baldwin N, Nowick AC. Pretransplant alssessment of nenal viability by phosphorus-31 magnetic resonance spectroscopy. Clinical experience in 40 recipient patients. Transplantation 1989:48:48-53

73. Yin L, Terasaki PI. A rapid quantitated viability test for transplant kidncys: Ready for human trial. Clin Transplantation $1988 ; 2: 295-298$

74. Andrews PM. Noninwasive vital microscopy to monitor tubular necrosis of cald-stored kidncys. Transplantation 1994:57:1143-1148

75. Youngner SJ, Amold RM. Ethical, phsychosocial, and public policy implications of procuring organs from non-heart-beating cadaver donors. JAMA 1993; 269:2769-2774

76. Obermann $\mathbb{K}$, Nagel E, Pichlmayr R. Ethical considerations in procuring organs from non-heart-benting donors after sudden cardiac death. Transplant Proc 1995; 27; 2924-2925

77. Schweizerische Akademie der Medizinischen Wissenschaften. Definitionen und Richtlinien zur Feststellung des Todes im Hinblick auf Organtransplantationen. Schweiz Äerzteztg 1995; 76; 868-876

78. de Wit RJ. Daemen JHC, Cumberland BG, Kootstra $\mathrm{G}$. Non-heart-beating kidney donation in uncontrolled donor procedures. Transplant Proc 1995; 27: 2922-2923

79. Shaw BW. Conflict of interest in the procurement of organs from cadavers following withdrawal of life support, in: Amolid RM, Youngner SJ, Schapiro R', Spicer CM (eds): Procuring Organs for Transplant: The Debate over Non-Heart-Beating Cadaver Protocols. Ballimore, Johns Hopkins Uniwersity Press, 1995, pp $103-111$

80. Kootstra G. Statement on non-heart-beating donor programs. Transplant Proc 1995:27:2965 


\section{CATEGORIES OF NON-HEART-BEATING DONORS}

G Kootstra, JHC Daemen, APA Oomen

Transplantation Proceedings 1995; 23: $2893-2894$ 


\section{Introducton}

In the past decade we the accumulated considerable experience with organ donation, mainy kidney, from non-heart-beating (NHB) domors [1]. Encouraged by the results and the many discussions with colleagues at workhops and meetrigs, we have learned that several categories of NHB donors can be distinguished. All these categories have their own pecultarties regarding preserwation, viability of organs and ethical aspects. Therefore, we consider it of importance for further development of this large potential source of organs for transplantation, that the discussion is structured and guided by the classification we have drafted. We distinguish four categories of NHB donors (lable 1).

Table 1. Categories of NHB donors

\begin{tabular}{|c|l|l|}
\hline Category & Dead on arrival & Uncontrolled \\
\hline Category 2 & Unsuccessful resuscitation & Uncontrolled \\
\hline Category 3 & Awaiting cardiac arrest & $\begin{array}{l}\text { Controlled or } \\
\text { Uncontrolled }\end{array}$ \\
\hline Category 4 & Cardiac arrest while brain dead & Uncontrolled \\
\hline
\end{tabular}

\section{Categortes of NHB donors}

The first category, category 1 , has a large potential and is called "Dead on artivar . Individuals in this category are declared dead outside the hospital and brought to the Emergency Room (ER) for donation purposes only. An attempt to resuscitate these patients has not been made because it would be obviously senseless io do so. The potential donors may have died of severe brain trauma or cervical fractures. Probably only kidneys will be recovered and viability is a major concem; data on the time of cardiac arrest must be precise and reliable. Another problem to overcome in this category / NHB donation is the need to re-route the dead body to the ER instead of to the morgue. Obtaining consent from relatives and legal auborities might cause delay and make donation virtually impossible. By immediate intra-aortic cooling upon arrival at the ER, organs could be obtained for donation. We have no knowledge of any 
program obtaining organs from category / NHB donors at this moment.

The next category is category 2: Unsuccessfid resurcitation. This concens patients brought into the ER while resuscitated by the ambulance crew. The resuscitation is taken over by the hospital tam. Whan this team decides to discontinue resuscitation because continued intervention proves to be unsuccessful, the transplant team is notified. They have to go over the available data and to decide whether a NHB donor procedure should be started. Important information is: the age of the succumbed, cause of death. kidney function, other diseases and last but not least, the time period between cardiac arrest and the moment of discontinuation of treatment. When the decision is made to stat the NHB donor procedure, in courtries with presumed consent legislation ("opting-oun") the cooling catheter can be introduced immediately. In countries without or with "opting-in" legislation, the time until consent for organ donation is obtained, has to be bridged. There are different protocols. Either cardiac massage and artificial ventilation are performed or this is not done. In Maastricht we bridge this period with cardiac massage and ventillation, although we would prefer to start the cooling instantly [2]. Legistation is on its way wherein "preparatory handling" is allowed in order to preserve the organs for transplantation before the person's or the family's wish is known.

Category 3 is called: Awaiting cardiac arrest. This category includes patients that are dying in the Intensive Care Unit and where the patient or the family have agreed on organ donation. When tratment is withheld, carciac arrest is waited for. Thereafter the cooling catheter is introduced and the deceased is transferred to the operating room for removal of the kidneys and, if possible, other organs. In the early days of transplantation when the principle of brainstem death was not yet established, this was the procedure of choice. It is referred to as "ventilator switch-off" procedure. We would like to propagate the use of the description "withdrawal of support", because there might be a situation in which the patient is not wentilator dependent. In the Pittsburgh protocol the waiting time is 2 minutes before cooling is started. We prefer to wait 10 minutes after cardiac arrest, to be sure that the pattent's brain is irreversibly damaged and an equivalent situation to brainstem death has been reached. These 10 minutes however, might preclude donation of other organs than kidneys. An example of a patient in this category is someone with a severe brain trauma who does not meet the criteriat of brainstem death. Nevertheless, the team that treats the patient has decided that it is useless to continue treatment. Another example is a patient with an end-stage neurological disease, for instance brain tumour with coma but without brainstem death. When the cardiac death of the patient is awated for in the operating room, and when after cardiac arrest the abdomen is opened for central cooling through the aorta, this procedure is referred to as "controlled" NHB donation. "Controlled"' means that under these circumstances the ischemia time 
is under control and can be kept to a minimum, and liver, pancreas and even lungs might be procured for transplantation [3].

The last category is Categorg 4: "Cardiac arrest while brain dead". This category includes patients who suffer an unexpected cardiac arrest either in the process of being diagnosed as brainstem dead or after the determination of brainstem death, but before they are taken to the operating room and organs could be retrieved. It is likely that at first it is tried to restore circulation. but when this is unsuccessful a NHB donor procedure may be started. In most cases consent to organ donation already has been granted at time of cardiac arrest and cooling can be employed instantly at the bed site.

\section{Discussion}

We distinguish four categories of $\mathrm{NHB}$ donors and we have experienced that exchange of ideas and structuring of a discussion on NHB donation can be guided through this classification system. So far we have not had access to category / subjects. It is difficult to realise the procedure, on the one hand because of the absence of relatives at time death - and it might take hours before they can be located - and on the other hand because of uncertainty of ischemia time. Nevertheless, the potential of donors in this category is large. Access to these donors requires a presumed consent legislation or a legislation that allows for starting of organ cooling to prevent kidneys from decay while the relatives are approached for obtaining consent for organ donation.

At the University Hospital Maastricht we have been successful in category 2 NHB donors and refusal rates are not thigher than in heart-beating situations. In several cases the family consented to introduction

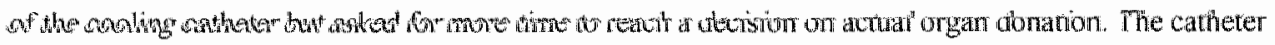
for colling is introduced and the kidneys are cooled in the intact body. Arrangements are made for family members to take leave of their deceased beloved one. In case of consent for organ donation the body is then brought to the operating room where the kidneys are removed.

The main ethical issue raised by category 3 NHB donation is that one decides to obtain organs before criteria for (brain) death are fulfilled. As stated above, we consider a period of 10 minutes of no intervention important, because in doing so, there will be a state that mimics the brainstem death state. Ten minutes of asystole and no blood circulation at normothermia results in irreversible damage of the brain. It will be practically impossible to diagnose brain death, and it is subject of discussion whether the waining period with no circulation should be 10 or 8 or even 15 minutes. 
Category 4 is a group of donors that obviously can serve as kidney donors when the heart function cannot be restored. We would like to stress that a set of instruments for the introduction of the cooling catheter should be available and ready at the bedside of every potential on declared donor in order to enable at least procurement of the kidneys in case of irreversible cardiac arrest. We have ancountared a special subgroup within this category, namely patients in whom branstem death has been diagrosed. but whose family cannot accept organ removal with a still beating heart. In a few such cases we have successfully obtained at the least kidneys by means of the NHB donor procedure after withdrawal of respiratory support and subsequent cardiac arrest.

In order to structure further discussion on NHB donation we propose the use of the fotr categories reviewed. In our experience they fulfil the goal of a better understanding of the NHB donot concept and a more clear discussion.

\section{References}

1. Vromen MAM, Leunissen KML, Persin GG, Kootstra G. Short-and long-term results with adult nonheart-beating donor kidneys. Transplant Proc 1988; 20: 743-745.

2. Heineman E, Daemen $\mathrm{JHC}$, Kootstra $\mathrm{G}$. Non-heart-beating donors: meihods and techniques, Transplant Proc 1995; 27: 2895-2897.

3. D'Allessandro AM, Hoffman RM, Knechtle SJ, Eckhoff DE, Love $\mathbb{R B}$, Kalayoglu M, Sollinger HW. Belzer fo. Successful extrarenal transplantation from non-heart-beating donors. Transplantation 1:995; $59: 977-982$ 
THE POTENTIAL POOL OF NON-HEART-BEATING KIDNEY DONORS

JHC Daemen, APA Oomen, WPA Kelders, G Kootstra

Clinical Transplantation 1997; 11:149-154 


\section{Introductions}

Solid-organ transplabtation has become acceptable as the treatment of choice for end stage organ falure. Ever since the routhe implementation of renal transplantation, however, the number of patients awaing transplantation outnumbered the number of kidneys avallable, and the total number of renal transplants perfomed is striclly limited by the availability of donor organs. Although within the Eurotransplant (ET) arganisation more cadaveric donors came available over the years, the number stabilised in the early $1990 \mathrm{~s}$ and railed to increase thereafter. Additionally, due to the more liberal criteria for entering the tramsplant waiting lists and re-entry of patierts having lost their primary graft, the waiting list has grown steeply and the discrepancy between demand and supply has increased. As a result, in the ET countries Austria, Belgium, Luwembourg, Germany and The Netherlands almost 11,000 patients were awaiting a renal transplant by the end of 1996, while little over 3,000 kidney transplants were performed that year [1].

Fighting this organ shortage is one of the challenges the transplant community has to face and various possibilities to alleviate this problem have been put forward. One of the most promising ways to increase the actual number of kidneys for transplantation, is expanding the donor pool with non-heart-beating (NHB) donors. Increased numbers of valuable organs have been reported by procuring kidneys from patients who died after irreversible cardiac arrest [2] and interest in NHB organ donation is growing. Although the pool of potential brain dead organ donors has been studied extensively in various ways [36], no reports exist evaluating the pool of patients dying of cardiac arrest that might be suitable NHB kidney donors. We therefore estimated by retrospective death chart review the number of potential NHB kidney donors that died at the Uniwersity Hospital Maastricht in one year. In this way we gain insight into the proportion of this NHB donor pool, and the signifficance towards alleviating organ shortage Itrough routine procurement of kidneys from NHB donors.

\section{Material and Methods}

The University Hospital Maastricht is located in the south of The Netherlands and is a hospital with 663 beds, including 16 Intensive Care Unit (ICU) and 22 Coronary Care Unit (CCU) beds. The hospital is serving a population of 209,000 with 20,440 admissions a year; it also serves as an academic referral center for other hospitals which account for $30 \%$ of the total number of admissions. Additionally, it houses a renal and pancreas transplant program, and has a long tradition in the procurement of kidneys from NHB donors within a NHB dlonor program that was installed in 1980. In general, kidneys from NHB donors are procured after an in-situ preservation (ISP) procedure, using a conling technique by 
femoral catheter. Our protocol for donor treatment and procurement has been described in extenso elsewhere [7].

The study criteria were according to the NHB donor criteria used within our protocol and involved all in-hospital deaths 3-65 y of age in the year 1994, including patients that died either just before or after admission to the Emergency Room (ER). Using the computerised registration of ICD-9-CM codes, codes of the International Classification of Diseases, patients known with malignancies other than primary brain tumours, and patients at time of death known to suffer from kidney disease, sepsis, severe uncontrollable hypertension, or suspect of intravenous drug abuse, were excluded. of the remaining patients, death charts were reviewed and abstracted (e.g. sex, age, cause of death, hospital unit, medical condition and kidney function at time of death); deaths with incomplete charts were excluded from the study. Patients with clinical signs of brain death, whether or not confirmed by isoelectric electroencephalogram (EEG), were considered potential brain dead heart-beating (HB) donors.

The charts were reviewed by transplantation experts to determine the deceased's medical suitability to be a NHB kidney donor. Since obviously not all patients are equally suitable as kidney donors, medical suitability was scored ( 1 to 3 ) according to renal function (last known serum creatinine) and the identification of risk factors that are thought to influence the outcome of NHB donor kidneys (age over 50, hypertension, diabetes mellitus) or to thwart the in-situ cooling (arterial vascular disease)(table 1). Patients medically unsuitable, regardless of the risk factors mentioned, were given suitability score 0 and were excluded. Although NHB donors have in common that organs are procured after cardiac arrest and subsequent period of warm ischemia, the total group is very diverse and categories of NHB donors have been identified and described by us [8]. These categories will be important in the transplant outcome of NHB donor kidneys. Category 3 (Awaiting cardiac arrest) and cafegory 4 NHB donars (Cardiac aresi whive brain dead) mimic HB donors with minimal ischemic damage to the organg, while organs from categary 2 NHB donors (Unswecessful reswsitation) have suffered considerable warm ischemia. Additionally, in category 3 and 4 NHB donation organ donation can be discussed before final cardiac arrest and ease preservation procedures. Logistics are important in the success rate of ISP procedures, and perfoming emergency procedures like ISP is easier at ICU and ER than at general wards. Therefore, also the logistic availability of potential donors (category, hospital unit) was scored (1 to 3). Again 0 scorers were expelled from further analysis (table 1). Finally, it was assessed whether suitable patients had become actual donors (i.e., ISP procedure had been started), permission for donation was refused by the relatives, or the deceased had not been identified as a potential NHB kidney donor. 
Table 1 . Scoring criteria for medical suitability and logistic awailability of potential WHB donors.

\begin{tabular}{|c|c|}
\hline Score & Medical suitability \\
\hline 0 & unsuitable \\
\hline 1 & creatinine $>100 \mu$ mol/L +2 or more risk factors ${ }^{a}$ \\
\hline 2 & $\begin{array}{l}\text { creatinine } \leq 100 \mu \mathrm{mol} / \mathrm{L}+2 \text { or more risk factors } \\
\text { or: creatinine }>100 \mu \mathrm{mol} / \mathrm{L}+0-1 \text { risk factors }\end{array}$ \\
\hline 3 & creatinine $\leq 100 \mu \mathrm{mol} / \mathrm{L}+0$-1 risk hactors \\
\hline Score & Logistic availability \\
\hline 0 & $\begin{array}{l}\text { dead on arrival (NHB donor category } /)^{\text {bl }} \\
\text { not available }\end{array}$ \\
\hline 1 & $\begin{array}{l}\text { unsuccessful resuscitation (NHB domor category 2) } \\
\text { general wards }\end{array}$ \\
\hline 2 & $\begin{array}{l}\text { unsucessful resuscitation (NHB donor categony 2)/ } \\
\text { ICU, CCU, ER, OR. }\end{array}$ \\
\hline 3 & $\begin{array}{l}\text { awaiting cardiac arrest (NHB donor category } 3 \text { ) or } \\
\text { cardiac arrest while brain dead (NHB donor category } 4) / \\
\text { ICU, CCU }\end{array}$ \\
\hline
\end{tabular}

a risk factors are: age $>50$, patient history of hypentension diabetes $s_{y}$ or arterial vascular disease.

categories of NHB donors; see ref. 8.

c. $\quad \mathrm{CU}=$ intensive care unit, $\mathrm{CCU}=\mathrm{coronary}$ care unit, ER=emergency room, OR woperating room. 
By combining the medical suitability and logistic awillabilyty scores in total score, the putential of NHB kidney donors and the likelihood that the donation would be effectuated successfully, were quantified. Total scores of 2-3, 4, or 5-6 points, were considered to reflect low (group A), moderate (group B), or tigh potential (group C) to become a successfully effectuated NHB kidrey donor, tespectively. Using this potential for success, estimations for the minimum and maximun numbers of NHB donors avaitable, were calculated. When appropriate, data are given as mean+SEM. Statistical analysis umployed nonparametric Mann Whithey-U test and chi-square tests for differences between groups.

\section{Results}

From a total of $603 \mathrm{in-hospital}$ deaths at the University Hospital Mastricht in 1994, there were 175 deaths among patients $3-65$ years of age; anoher 25 deatlus in this age group were reported from the ER. Computer analysis of these deaths revealed 82 patients diagnosed at time of death with ICD-9.CM codes that precluded kidney donation. No data were avallable from 9 deaths; death charts of 109 patients were studied. Subsequent expert review of the charts showed that another 45 patients were in a medical condition at time of death that made kidney donation impossible (e.g. long agonal phase, suspect of carcinoma, unsuitable medical history); 8 patients seemed to have become clinically brain dead, which had been confirmed by EEG when organ donation was considered ( 7 cases). The potential of HB donors therefore was 8 ; the remaining 56 were considered to be potential NHB donors (fig. 1).

The scores for medical suitability, logistic availability as well as the combined total scores are depicted in table 2 ; the combined scores in table 3 . The latter showed that 27 deceased patients had a high potential of becoming a successfud NHB kidney donor (group C, score 5-6), while 22 patients scored 4 (group B, moderate potential) and 7 scored 2-3 (group A, low potentiall). Estmations of the potential number of NHB donors avalable therefore ranged from $27-56$, i.e. $4.5-9.2$ NHB donors/.00 inhospital deaths, depending on whether only potential donors from group $\mathrm{C}$ were included, or all potential NHB donors (groups A, B, and C).

Potential NHB donors were predominanty male $(70 \%)$, aged $49.1 \pm 1.8 y$, and serum creatinine $100.1 \pm 6.8$ Hmol/L. Most of them died of acute heart failure $(55 \%)$, cerebrall trauma $(13 \%)$, or ceretbral bleeding/anoxia ( $14 \%$ ). They died at ER (36\%), ICU (20\%), CCU (13\%), operating room (OR)(13\%), and general wards $(20 \%)$. Attending physicians at time of death were cardiologists $(45 \%)$, neurologists $(18 \%)$, cardiopulmonary surgeons $(16 \%)$ or general surgeons $(7 \%)$. Forty-nine (88\%) of all pottential NHB donors were identified as category 2 NHB donors, that died after an unsuccessful resuscitation 
Fingure 1. Selection process for potential NHB donors

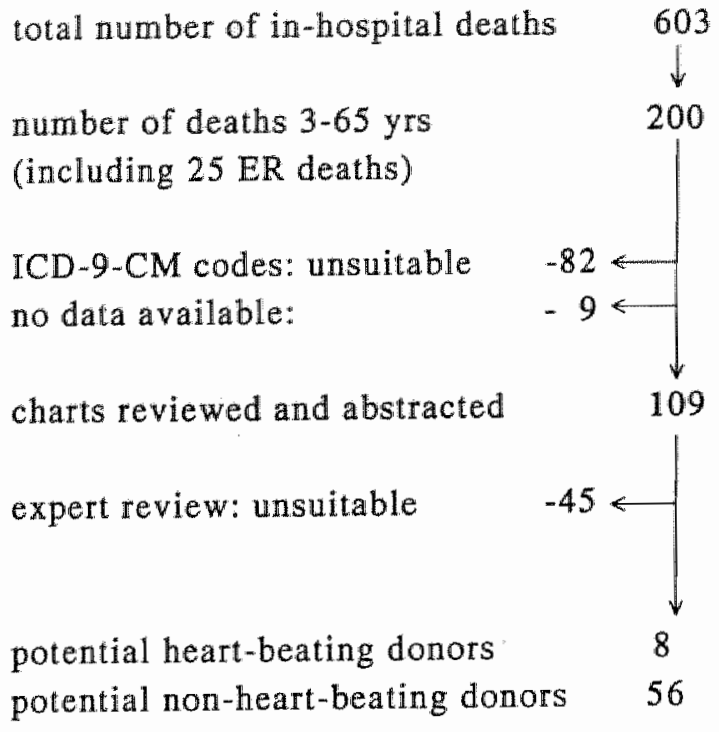

"Table 2. Scoring results of potential NHB donors ( $\mathrm{n}=56$ )

\begin{tabular}{|c|c|c|}
\hline score $^{a}$ & medical suitability (n) & logistic availability (n) \\
\hline 1 & 2 & 11 \\
\hline 2 & 24 & 37 \\
\hline 3 & 30 & 8 \\
\hline
\end{tabular}

"See criteria outlined in table 1. 
attempt. The rest was identified as categon 3 NHB donors; none was identified as an cotegory 4 NHW donor. When comparing potential donors in group C with the remaining potential donors (groups A-B), there were no differences except for senm creatinine $(76.8+7.9 \mathrm{vs} .109 .548 .4$ Lmol/L, respectively: $p=0.01)$ and for hospital unit where the patient died (24/27 at ER, ICU, or CCU vs. 11/29, respectively: $\mathrm{p}=0.001)$.

Table 3. Potential of successful NHB kidney donation

\begin{tabular}{|l|c|c|c|}
\hline Potential & Total score $^{\text {a }}$ & Group & n \\
\hline Low potential & $2-3$ & A & 7 \\
\hline Moderate potential & 4 & B & 22 \\
\hline High potential & $5-6$ & C & 27 \\
\hline
\end{tabular}

a Total scores are the combined scores for medical suitability and logistic availability of the potential donors.

Of the 56 potential NHB donors at our instirution, 20 were identified as such; in one case identification of the donor was not possible and consent from the next of kin could not be obtained in time lo start organ preservation. Consent to donation was refused in $6 / 19$ casses $(32 \%)$, equal to our refusal rate in HB donation. Thirteen (68\%) became actual donors; in 1 case legal consent was withdrawn by the District Attomey after a successful ISP procedure. Not identified and therefore missed potential donors only differed from identified potential NHB donors in their serum creatinine levels $(91.9+6.6 \mathrm{vs} .126 .3+17.2$ $\mu$ mol/L; $p=0.04$ ), and they were more often attended by physicians other than cardiologists ( $p<0.001)$. Apart from loosing donors due to refused permission for organ donation, actual donors were lost because of technical failures. Through projection of the figures for refusal and technical failure onto the $27-56$ estimated potential NHB donors, the number of kidneys that would actually come available is callculated to be 24.0-49.6 per year (table 4). 
Table 4. Projected number of NHB donor kidneys available

\begin{tabular}{lllll}
\hline Estimation & High & Moderate & Low & HB $^{\text {al }}$ \\
\hline $\begin{array}{l}\text { Potential donors } \\
\text { Refusal rate (32\%) }\end{array}$ & 56 & 49 & 27 & 8 \\
& 17.9 & 15.7 & 8.6 & 2.6 \\
Actual donors & 38.1 & 33.3 & 18.4 & 5.4 \\
Technical failures (35\%) & 13.3 & 11.7 & 6.4 & - \\
\hline & & & & 10.8 \\
\hline
\end{tabular}

\section{Discussion}

The success of renal transplantation is limited by the number of organs available. The growing demand for kidneys is accompanied by an insufficient supply of organs. In fact, in the ET area in 1994 donor rates decreased by $10 \%: 13.9$ donors were effectuated per million population (p.m.p.) versus 15.4 in 1993, resulting in 26.4 kidneys p.m.p. available for transplantation [1]. Numerous studies have been conducted to estinnate the potential donor supply, directed towards the identification of potentially brain dead pattients. Although study designs differed (prospective-retrospective, review of in-hospital death charts at various hospital units, or identification of potential donors from large mortality data bases), inwariably it was concluded that the potential number of cadaveric organ donors is far larger than the numbers effectuated. The calculated numbers of potentially brain dead donors show considerable variation, roughly from 28 to over $100 \mathrm{HB}$ donors p.m.p., due to the criteria used to in- and exclude patients as suitable donors and the way of extrapolating study results to larger populations [3-6,9-12].

There are several options to fight the huge disparity between the numbers of donor kidneys demanded and available. Athough the best transplant results are achieved with organs from living donors [13], the 
supply will probably never suffice since their awailability is limited by personal and cultural condinons. Within ET currently 7\% of renal transplants are performed with organs from living related donors [1]. Organ shortage will also be alleviated by a more efficient use of the grafts avilable through improving transplant results. Ongoing research forts will improve immunosuppressive regimens that might reduce the loss of transplanted gratts due to acute and chronic rejection. Additionally, overall gratt survival may be increased through more strict selection of recipients with regard to age physical condition. retransplantation, and sensitisation grade. Xenotrunsplantation, although mabe feasible in the future, is not an option at the moment [14].

The most direct option with the largest potential is increasing the number of cadaveric ongan donors. Much can be achieved in identifying potential organ donors, improving consent rates, and increasing transplant activities by implementation of organisations for procurement, education, and transplant coordination $[15,16]$. Feest et al. [17] reported doubled donation rates after introduction of a protocol to initiate ventilatory and hemodynamical support for the sole purpose of organ donation in patients with lethal cerebrovascular incidents. Over the years donor criteria have become more liberal and so called marginal donors are increasingly used to expand the donor pool [18]. All these efforts, llowever, are primarily directed to increase the number of $\mathrm{HB}$ donors, although probably less then $6 \%$ of patients dying in hospitals will be diagnosed brain dead $[10,19]$. Far larger is the estimated propontion of potentially suitable donors reponted to die of cardiac arrest before ventilation is started $(57 \%)$, or while on respiratory support but before brainstem death can be confirmed (12-21\%)[20,21]. All these patients must be considered potential NHB donors.

Organs from $\mathbb{N H B}$ donors can be procured and transplanted successfully, as reported by several authors [22-25]. In fact, before the notion of brain death was generally accepted all transplants were performed with organs from NHB donors; these donors sustained cardiac artest after withdrawal of ventilatory support in the OR. Even today, in countries where brain death is not accepted, this is the only way of procuring organs. Later, emergency procedures were developed for organ salvage from donors with unexpected and irreversible cardiac arrest [26-28] and implementation of such protocols resulted in at least $20 \%$ more kidneys transplanted $[2,29]$.

The proportion of potental NHB donors, however, is much more impressive. As revealed by this study, in addition to the potential eight HB donors, $27-56$ NHB donors were found resulting in a projected annual 2 to 4.5 fold increase of kidneys available for transplantation (table 4). Nathan [30] estimated at potential of 123 (range 104-183) NHB donors p.m.p. from a computer algorithm of in-hospital deaths 
in the United States. This number was twice as high as the projected pool of estrmated HB donors. Introduction of routine kidney procurement from NHB donors in, for example, only the University Hospilals in The Netherlands, would already have major consequences for the Dutch renal warting list. Assuming that all eight University Hospitals are comparable with regard to patient population and causes of death, their reponted 4860 in-hospitall deaths in 1994 may have included a number of 217.6 to 451.3 potential NHB kidney donors. The extrapolated total number of kidneys available from these eight centers, with presumably equal refusal and failure rates as found in our center, thus could be as high as 143.6 to 297.8 annually. For The Netherlands this would be equivalent to a rise of $9.4-19.4$ kidneys p.m.p. These additional organs for transplantation would at least stop the waiting list from growing.

Through employing a scoring system in our study, we tried to correct for factors that may hamper preservation procedures and reduce the chance on a successful donation procedure. Logistically it is much more demanding to perform ISP procedures at general wards than at specialised ICU or CCUs; introduction of this kind of procedures needs education, training and dedication towards donation. However, $38(68 \%)$ of the identified potential NHB donors in our estimate were located at ER, ICU, and CCU; hospital units traditionally well equipped with highly trained personnel that often is familiar with emergency and donation procedures. Additionally, $21(70 \%)$ of the 30 potential NHB donors with the highest medical suitability scores were found at these units as well. Focusing on NHB donation at ER, $I C U$, and $\mathrm{CCU}$ wards might therefore be justifiable as this option is the most promising with regard to success and would still improve donation rates remarkably.

For the calculated numbers of kidneys eventually available, a technical failure rate was taken inio account. In the period 1993-1995 malpositioning and impossible insertion of the cooling catheter, together with nupture of balloons, accounted for a loss of $35 \%$ of donors, category 2 NHB donors mostly. This figure is consistent with the failure rate of procedures reported by Dunlop et al. [31]. However, through using a redesignedwcooling catheter (Porgès AJ 6516) and checking catheter position by X-ray, this faillure rate could be reduced. Apparently, techniques can still be improved thrther which will increase the actual number of organs avalable per potential NHB donor. Not surprisingly, category 2 NHB donors, i.e., patients dying of unexpected or sudden cardiac arrest, account for $88 \%$ of the identified potential in this estumate. Essential in limiting the ischemic damage to the organs and keep the option of organ donation in this category, is to start in-situ cooling as soon as possible after cessation of circulation. In countries with opting-in legislation, an important burden in this so called uncontrolled NHB donation is the fact that also consent for preservation is mandatory before organ coaling may be initiated. Presumed-consent legal systems, or legislation that allow preservation of organs without 
consent if relatives cannot be approached immediately, offer the possibility to minimise the duration of ischemia and thus optimise the success of NHB organ donation.

This study has shown that the pool of potential NHB kidney donors is considerable; 2 to 4.5 fold increased numbers of kidneys may come available fron NHB donors when compared to the estimated number of $\mathrm{HB}$ donor kidneys. With at least a doubling of the number of renal grafts, the acute shortage of kidneys for transplantation will be fought successfully and waiting lists will no longer grow. We recommend the introduction of kidney procurement from NHB donors at ER, ICU, and CCL, as donation activities at these hospital units will be the most effective and successful. As most NHB donors are uncontrolled category 2 NHB donors, a legal system based on presumed-consent that allows preservation of organs without consent, enables optimal availability of the pool of potential NHB kidney donors.

\section{Acknowledgement}

The authors wish to thank Mr. John Vossen for making hospital computer data available.

\section{References}

1. de Meester J. Kidney: Donation, waiting lists and transplants. In: Cohen B, Persijn GO, de Meester J (Eds) Eurotransplant International Foundation / Annual. Report 1996, gegevens Koninklijke Bibliotheek, The Hague, Netherlands; 1997: pp. 27-32

2. Kootstra $\mathrm{G}$, Wijnen RMH, van Hooff JP, van der Linden Cl. Twenty percent more kidneys through a monheart-beating donor program. Transplant Proc 1991; 23: $910-911$

3. Gore SM, Hinds CJ, Rutherford AJ. Organ donation from intensive care units in England. BMJ 1989; 229: 1193-1197

4. Kodde JH, Kerkhoff AHM. Estimate of the potential numbers of donor organs in 13 hospitals with a large neurosurgical deparmant. Ned Tijdschr Geneeskd 1992; 136:839-844.

5. Gäbel H, Edström B. Number of potential cadaveric donors: neasons for nonprocurement and suggesthons for improvement. Transplant Proc 1993; 25:3136

6. Evans RW. The actual and potential supply of organ donors in the United States. In: Terassaki Pl, Cecka JM (Eds). Clinical Transplants 1990, UCLA Tissue Typing Laboratory, Los Angeles _CA; 1991: pp. 329. 341

7. Heineman E, Daemen JHC, Kootstra G. Non-heart-beating donors: methods and techniques. Transplant Proc 1995; 27: 2895-2897

8. Kootstra $\mathrm{G}$, Daemen JHC, Oomen A.PA. Categories of non-heart-beating donors. Transplant Proe 1995; $27: 2893-2894$ 
9. Bart $\mathrm{KJ}$, Macon EJ, Whitier $\mathrm{FC}^{2}$, Baldwin $\mathrm{R}$, Bloum IH. Cadaveric kidneys for transplantation: a paradox of thortage in the face of plenty. Transplantation 1981;31:379-382

10. Garrison RN, Bentley FIR , Raque GH, Polk HC, Sladek LC, Evanisko MJ, Lucas BA. There is an answer to the shontage of organ donors. Surg Gyn Obst 1991; 173: 391-396

11. Nathan HM, Janrell BE, Broznik B, Kochic R, Hamilon B, Stuar S, Ackroyd T, Nell M. Estimation and characterization of the potential renal organ donor pool in Pennsylvania. Transplantation 1991; $51: 142$ 149

12. Evans RW, Oriang CE, Ascher NL. The potential supply of organ donors: an assessment of the efficiency of organ procurement efforts in the United States. IAMA 1992; 267: 239-246

13. DAllesgandro AM, Sollinger $\mathbb{H W}$, Knechtle SJ, Kallayoglu M, Kisken WA, Uehling DT, Moon TD, Messing EM, Braskewitz RC, Pirsch ID, Belzer FO. Living related and unrelated donors for kidney transplantation: a 28-year experience. Ann Surg 1995; 222: 353-364

14. Alexander JW. The cutting edge: at look to the future in transplantation. Transplantation 1990; 49:237-240

15. Matesanz R, Miranda B, Felipe C. Organ procurement in Spain: impact of transplant coordination. Clin Transplantation 1994; 8:281-286

16. Cumberland BG, de Wit RU, Kootstra G. Organ and tissue procurement rates improve after professional healthcare education by hospital development coordinators and hime sensitive requesting. Transplant Proc $1995 ; 27: 2957-2958$

17. Feest TG, Riad HN, Collins CH, Golby MOS, Nicholls AJ, Hamad SN. Protocol for increasing organ donation after cerebrovascular deaths in a district general hospital. Lancet 1990; 335: 1133-1135

18. Alexander JW, Zola JC. Expanding the donor pool: use of marginal donors for solid organ transplantation. Clin Transplantation 1996:10:1-19

19. Hibberd AD, Pearson IY, McCosker CJ, Chapman JR, Macdonald GS, Thompson JF, O'Connell D, Mohacsi PJ, Mcl.ough lin MP, Spratt. PM. Compton IS, Brown MA. Potential for cadaveric organ retrieval in New South Wales. BMJ 1992; 304: 1339-1343

20. Salih MAM, Harvey I, Frankel S, Coupe DJ, Webb M. Cripps HA. Potential availability of cadaver organs for transplantention. BMJ1991; 302:1053-1055

21. Thompson JF, McCosker CJ. Hibberd AD, Chapman JR, Compton JS, Mahony JF, Mohasci PJ. Maredonald $\mathrm{OJ}$, Spratt PM. The identification of potential cadaveric organ donors. Anaesth Intens Care $1995 ; 23: 75-80$

22. Wiinen RMH, Booster MH, Stubenitsky BM, de Boer J, Heineman E, Kootstra G. Outcome of dransplantation of non-heart-beating donor kidneys. Lancet 1995; 345: 1067-1070

23. Casavilla A, Ramirez C, Stapiro R, Nghiem D. Miracle K. Bronsther O. Randhawa P, Broznick B, Fung J, Stazl TE, Experience with liwer and kidney allografts from non heartbeating donors. Transplantation 1995; 59: 197 203

24. DAlessandro AM, Hofmann RM, Knechtle SJ, Sollinger HW, Kalayogla M. Pirsch JD, Belzer FO. Controlled non-weart-beating renal donation in the cyclosporine era. Abstract (0-30), 3 rd International Congress of the Society for Organ Sharing, Paris, France, July 17.19.1995 
25. Schlumpf R, Weber M, Weinreich T, Kloc H, Zolinger A, Candinas D. Transplantation of Kidneys from non-heart-beating donors: an update. Transplani Proe 1995; 27: 2942-2944

26. Garcia-Rinaldi R, Lefrak EA, Defore WW, Feldman L, Noon GP, Jachinczyck JA, Debakey ME. In sith preservation of cadaver kidneys for transplantation: laboratory observatuons and clinical application. Ann Surg $1975 ; 182: 576-584$

27. Anaise D, Smith R, Ishiman M, Waltzer WC, Shabtai M, Hurley S, Rapaport FT. Am approach to organ sallwge from non-hearbeating cadaver donors under existing legal and ethical requirements for transplartation. Transplantation 1990; 49:290-294

28. Vroemen JPAM, van der Vliet JA, Kootstra G. The emergency in situ preservation of kidneys for transplantation. Neth J Surg 1983; 35; 55-59

29. Varty K, Veitch PS, Mogan JDT, Bell PRF. Kidney retrieval from asystolic donors: a valuable and viable source of additional organs. Brit I Surg 1994; $81: 1459-1460$

30. Nathan HM. How mary organs would be made available from non-heart-beating donors? An estimate of U.S. potential donor pool. Presented at the 26 th CTTC meeting, Lyon, France, June 13-15, 1994

31. Dunlop P, Varty K, Veich PS, Nicholson ML, Bell PRF. Nor-heart-beating donors: the Leicester experience. Transplant Proc 1995; 27: 2940-2941 
SHORT-TERM OUTCOME OF KIDNEY TRANSPLANTS

FROM NON-HEART-BEATING DONORS

AFTER PRESERVATION BY MACHINE PERFUSION

JHC Daemen, RJ de Wit, MWGA Bronkhorst, ML Marcar, M Yin, E Heineman, G Kootstra Transplant International 1996; 9 (suppl): $76-80$ 


\section{Introditution}

In the surge for ways to reduce the organ shortage non-heart-beating (NHB) donors are recognised as a valuable source of organs for transplantation. After irreversible cardiac arrest and the subsequent. diagnosis of death, organs can be procured and used for transplantation, especially kidneys are known to tolerate ischemia well [ ]]. The University Hospital Maastricht has had a NHB donor program for over a decade and procures and transplants kidneys from NHB donors [2]. Analysis of the transplantation oulcome with these renal grafts showed a high incidence of delayed function (DF) due to acute ubular necrosis (ATN) when compared to grafts from heart-beating (HB) donors [3]. From experimental data it is known that preservation of ischemically damaged kidneys by machine perfusion (MP) is superior to simple cold storage $(\mathrm{CS})[4,5]$. In order to reduce the DF rate of kidney grafts from NHB donors we recently implemented MP as the prefered method of preservation. In this study the results of 22 renal grafts from NHB donors preserved by MP are evaluated and compared with a historical control group of graftix from NHB donors preserved by CS.

\section{Material and Methods}

Pations dying after irewersible circulatory arrest in the Emergency Room or Intensive Care Unit, were considered potential NHB donors when meeting the following criteria: circulatory arrest no longer than 30 min excluding the time of effective resuscitation and a total resuscitation ime not longer than $2 \mathrm{~h}$. The upper age limit was consiclered to be $65 \mathrm{y}$ and the potential donors were not known to suffer from kidney disease, uncontrolled hypertension or metastasising malignancies. Patients with signs of sepsis or intravenous drug abuse were excluded. All donors came either available after an unsuccessful attempt of cardio-pulmonary resuscitation (category 2 NHB dowors) or sustained final cardiac arrest after withdrawal of ventilatory support (category 3 NHB donors)[6]. After consent, an in-situ perfusion procedure using a double-balloon-triple-lumen cooling catheter (Porges AJ 6516) according to a technique described before, was performed [7]. Afterwards the kidncys were procured in the operating room. The organs were preserved by either CS, using Euro-Collins (EC), histidine-tryptophan ketoglutarate (HTK) or University of Wisconsin (UW) CS solutions, or by MP in a Gambro-PF3B perfusion machine using a UW derived machine preservation solution as a perfusate [8]. The in-situ flush out was performed using the respective CS solution, or HTK in all MP cases. During MP flow characteristics and enzyme loss were recorded to evaluate the viability of the kidney. Because of these parameters, among others, kidneys were discarded and not used [9]. Kidneys transplanted within the Eurotransplant area were inchuded and data were collected by approaching the transplant centers. 
Short-term posttransplant function was classified as: (a) immediate function (112), i.e. immediate lifesustaining renal function without postransplant dialysis; (b) DF, i.e. retal function that witumately was life-sustaining but required one or more dialysis sessions; (c) primary nonfunction (PNF), i.e. renal function failed and the patient never was without dialysis. Renal function was recorded as senm creatinine at 1 and 3 months after transplantation. DF was quantified by wine output during the first 24 h posttramsplant, the duration of DF (number of days) and number of dialysis sessions required. The warm ischemia time (WIT), i.e, time elapsed between cardiac arrest and in-situ organ cooling, tended to be longer in the MP group. Therefore, the results of transplanting kidneys with prolonged wam ischemia, WIT of 45 min or more, were analysed separately.

The results are given as mean \$ SEM. Statistical analysis employed the chi-squared test with Yates' correction or Fisher's exact test, Mann- Whitney U-test and Kruskal-Wallis one-way ANOVA test for differences between the groups, as appropriate. A p-value of less than 0.05 was considered significant.

\section{Results}

Between July 1993 and December 1994, 22 kidneys were recovered from 14 NHB donors, preserved by MP and subsequently transplanted. In the control group 57 kidneys from NHB donors were transplanted. after preservation by CS in the period 1980-1992. Causes of death showed more brain tratma in the CS grotip while more patients died after myocardial infarction in the MP group $(p=0.001)$. Data conceming donor and recipient factors are summarised in table 1 . Donor age was $40.7+2.3 y$ in the $C S$ group and $45.8+3.7 y$ in the MP group $(p=0.21)$; last serum creatinine level of the donors was $101.6+4.9$ and $111.6 \pm 9.4 \mu \mathrm{mol} / \mathrm{L}$, respectively $(p=0.35)$. Kidneys in the CS group sustained a WIT of $33.1 \pm 2.9 \mathrm{~min}$ versus $52.0+7.9$ min in the MP group $(\mathrm{p}=0.10)$. Forty-1wo (74\%) were cold stored in EC, 14. $24 \%$ in $\mathrm{HTK}_{\text {, and }} \mid(2 \%)$ in UW; in the MP group one prir of kidneys was initially fushed with EC and all others with HTK.

Mean cold ischemia time (CVT) was $31.5 \pm 1.1$ h for cold-stored grafts and $30.2 \pm 1.2 \mathrm{~h}$ fol machine perfused grafts $\left(\mathrm{p}^{=0.50)}\right.$ ). Recipient data in either group were comparable for age, sex, number of the graft, and peak level of panel-reactive-antibodies. In the MP group the mean HLA-DR mismatch was $0.6 \pm 0.1$ ws $0.3 \pm 0.1$ in the CS Group $(p=0.03)$. Mean anastomosis time was shorter in the CS group $(36.2+2.0 \mathrm{~min}$ vs $40.7 \pm 3.4 \mathrm{~min}, \mathrm{p}=0.05)$. Short-term posttransplant outcome is summarised in table 2 . Results were comparable for both groups, reflected by similar immediate posttransplant urine output and equal duration of DF, number of dialysis sessions, and kidney function at $\mathbb{1}$ and 3 months. In the separate 
Table 1. Donor and recipicnt data ${ }^{\text {a }}$

\begin{tabular}{|c|c|c|c|}
\hline & $\mathrm{Cs}$ & $\mathrm{MP}$ & p-value \\
\hline Period & $1980-1992$ & $1993=1994$ & \\
\hline Cases & 57 & 22 & \\
\hline \multicolumn{4}{|l|}{ Donor data } \\
\hline$\overline{\operatorname{Age}(y)}$ & $40.7 \pm 2.3$ & $45.8 \pm 3.7$ & 0.21 \\
\hline Creatinine ( $\mathrm{mol} / \mathrm{L}$ ) & $101.6 \pm 4.9$ & $111.6 \pm 9.4$ & 0.35 \\
\hline WIT (min) & $33.1 \pm 2.9$ & $52.0 \pm 7.9$ & 0.10 \\
\hline \multicolumn{4}{|l|}{ Recipient data } \\
\hline Age $(y)$ & $44.9 \pm 1.7$ & $49.0 \pm 3.1$ & 0.19 \\
\hline $\operatorname{crr}(h)$ & $31.5 \pm 1.1$ & $30.2 \pm 112$ & 0.50 \\
\hline Anastomosis time (min) & $36.2 \pm 2.0$ & $40.7 \pm 3.4$ & 0.05 \\
\hline Graft number & $1.2 \pm 0.1$ & $1.1 \pm 0.1$ & 0.80 \\
\hline HLA-DR mismatch & $0.3 \pm 0.1$ & $0.6 \pm 0.1$ & 0.03 \\
\hline CyA immunosuppression & $35(38 \%)$ & $18(82 \%)$ & 0.05 \\
\hline
\end{tabular}

Results are given as meandSEM or numbers $(\%)$

Table 2. Short-tierm outcome up to 3 months posttransplantation ${ }^{\text {a }}$

\begin{tabular}{|c|c|c|c|}
\hline & $\mathrm{Cs}$ & $M P^{\prime}$ & p-vallue \\
\hline Cases & 57 & 22 & \\
\hline Inmediate function & $15(26 \%)$ & $8(36 \%)$ & \\
\hline Delayed function & $34(60 \%)$ & $\|(50 \%)$ & 0.67 \\
\hline Primary nonfuncition & $8(14 \%)$ & $3(14 \%)$ & \\
\hline Urine output (m// st $24 \mathrm{~h})$ & $836.9 \pm 154.1$ & $1465.2+540.2$ & 0.66 \\
\hline Duration of DF (days) & $17.2+1.7$ & $18.9+2.8$ & 0.63 \\
\hline Number of dialyses & $6.0 \pm 0.8$ & $5.5 \pm 1.2$ & 0.84 \\
\hline Creatinine I mo (Hanol/L) & $338.5 \pm 46.1$ & $324.5 \pm 69.4$ & 0.58 \\
\hline Creatinine 3 mo $(\mu$ mol/L) & $1942=13.8$ & $264.8 \pm 44.8$ & 0.39 \\
\hline
\end{tabular}

"Results are given as meantSEM or numbers $(\%)$. 
analysis (conceming prolonged ischemia time defined as WTT of 45 min or more), 17 kidneys (30\%) in the CS group sustained prolonged warm ischemia (WTT 59.74 .3 min ws 10 kidneys (4.5\%) in the MP group (WIT $89.0 \pm 6.2 \mathrm{~min}, \mathrm{p}=0.002$ ). Results are depicted in table 3 . All donor data were comparable; for recipient data again the anastomosis time was different (CS group 29.942.3 min vs MP group $47.5+4.1 \mathrm{~min}, \mathrm{p}=0.001$ ). In table 4 the posttransplant outcome of kidney transplantis with prolonged wam ischemia is summarised. It is shown that this outcome was better in the MP group when compared to the CS group $(p=0.02)$, reflected by lower serum creatinine at 1 month $(p=0.05)$; serum creatinine at 3 months showed statistically no significant difference $(p=0.50)$. Length of DF and number of dialyses required were the same.

\section{Discussion}

Although kidneys from NHB donors have been used ever since the first transplantation, ways have to be found to ameliorate ischemic damage through optimal methods of preservation and minimisation of reperfusion injury, in order to develop this valuable source of transplantable organs. Studies on the transplantation results with kidneys from NHB donors show DF rates as high as $60-75 \%$, almost twice as high as for gratts from $\mathrm{HB}$ donors [3,10-15]. This delayed onset of renal function is unfavourable; DF is masking the signs of early acute rejection, will complicate the post-operative treatment and reinstitution of dialysis will have a negative impact on the patient's psyche. Consequently hospital stay will be prollonged and costs increased $[16,17]$. The effect of DF on graft survival is controversial; some believe DF is associated with reduced graft survival, while others suggest that DF only in combination with acute rejection is responsible for worse transplant outcome [18-23]. In spite of doubled DF rates, long-term graft and patient outcome did not differ between recipients of NHB and HB kidneys [3].

To reduce DF rates we introduced MP in 1993 as the method of preserwation for NHB donor kidneys using the UW preservation solution for MP as a perfusate. Nowadays, CS is accepled as the nethod of choice for the preservation of renal grafts; the advantages of preservation by continuous cold perfusion are most pronounced for prolonged preservation limes and for kidneys from marginal donors with ischemic damage $[4,24]$. Recent experimental work at our laboratories showed that preserwation of ischemically damaged kidneys by MP was superior to preserwation by $\mathrm{CS}$. MP counteracts the intra-renal vascular resistance induced by ischemia, providing better reperfusion and delivering oxyger and nutrients to and removing waste products from the organ during preservation. This resulted in better survival of the animals and better preservation of the microcirculatory integrity $[5,25]$. The superiority of MP has been confirmed in clinical tramsplantation on severdil occasions and recently 
Table 3. Donor and recipient datta for kidneys with WTI of 45 min or more

\begin{tabular}{|c|c|c|c|}
\hline & $\mathrm{CS}$ & $M P$ & p-value \\
\hline Period & $1980-1992$ & $1993-1994$ & \\
\hline Cargess & 17 & 10 & \\
\hline \multicolumn{4}{|l|}{ Domordata } \\
\hline Age $(y)$ & $42.4 \pm 3.9$ & $52.6 \pm 5.2$ & 0.08 \\
\hline Creatinine (Hmol/L) & $114.6 \pm 8.6$ & $121.4 \pm 5.4$ & 0.44 \\
\hline WTT $(\min )$ & $59.7 \pm 4.3$ & $89.0 \pm 6.2$ & 0.002 \\
\hline \multicolumn{4}{|l|}{ Recipient data } \\
\hline Age & $44.8 \pm 3.8$ & $51.7+4.2$ & 0.27 \\
\hline $\mathrm{ClIT}^{\circ}(\mathrm{h})$ & $30.8+2.2$ & $29.6 \pm 1.9$ & 0.56 \\
\hline Anastomosis time (min) & $29.9 \pm 2.3$ & $47.5 \pm 4.1$ & 0.001 \\
\hline Graft number & $1.3 \pm 0.2$ & $1.2 \pm 0.1$ & 1.0 \\
\hline HLA-DR mismatch & $0.3 \pm 0.1$ & $0.5 \pm 0.2$ & 0.22 \\
\hline CyA immunosuppression & $13(76 \%)$ & $8(80 \%)$ & 0.83 \\
\hline
\end{tabular}

Results are given as mean + SEM or numbers $(\%)$.

Table 4. Short-term outcome of kidneys with WIT of 45 min or more

\begin{tabular}{|c|c|c|c|}
\hline & $\mathrm{cs}$ & MP & p-value \\
\hline Cases & 17 & 10 & \\
\hline Immediane function & $4(2 \% \%)$ & $5(500 \%)$ & \\
\hline Dotnyed function & $13(76 \%)$ & $3(30 \%)$ & 0.02 \\
\hline Primary nonfunction & $0(0 \%)$ & $2(20 \%)$ & \\
\hline Urine output (mil/ st $24 \mathrm{~h}$ ) & $959.5 \pm 323.5$ & $1734.8 \pm 998.0$ & 0.70 \\
\hline Duration of DF (days) & $17.2 \pm 2.4$ & $12.7 \pm 1 . \overline{8}$ & 0.42 \\
\hline Number of dualyses & $4.8+0.9$ & $5.3 \pm 1.3$ & 0.93 \\
\hline Creatinine 1 mo (pmol/L) & $408.6+76.9$ & $197.3+26.3$ & 0.05 \\
\hline Creatinime 3 mo (fumol/L) & $197.4 \pm 23.0$ & $163.3 \pm 14.9$ & 0.50 \\
\hline
\end{tabular}

${ }^{\text {At }}$ Results are given as meantSEM or numbers $(\%)$. 
impressive results were reported with NHB donors after presenation by MP [26-29]. Kidneys were from categony 3 NHB donors only and sustained considerably less ischemia than our series and showed merely $19-22 \%$ DF rate $[30,31$ ]. In the present analysis, the DF rate in the MP group was $50 \%$ compared to $60 \%$ in the CS group.

Apart from donor type (cadaver vs living donor and NHB vS HB donor) and the preservation mode, several other factors have been identified as risk factors for ATN and DF. Retransplantation, warm ischemia time, type of preservation solution, preservation time ard number of HLA-DR mismatches hwe all been supposed to worsen early postransplant function $[3,16,17,23,32,33]$. In this analysis several of these factors were studied and some appeared to be statistically significant different between the study group and historical controls. For the machine perfused kidneys the anastomosis time was longer as well as the WTT; the evident worse match on HLA-DR antigens in the MP group further deveriorates the early posttransplant function of these grafts. The results of the comparison between CS and MP groups therefore may be biased to the detriment of the MP group concerning transplant outcome. However, although considered to be more profoundly damaged than the NHB donor kidneys in the CS group, the grafted kidneys preserved by MP" showed equal short-term outcome when compared to grafts preserved by CS. In a previous analysis we showed that the elevation of senum creatinine at 1 month posttransplant when compared to HB donors, was transient and neutralised at 3 months, not affecting long-term graft outcome [3].

In the last few years increased efforts have been made to identily potential NHB donors and it was noticed that in our program more category 2 NHB domors were accepted after long resuscitation efforts. This fact is reflected by the increased number of donors dying after myocardial infarction and unsuccessful resuscitation; momentarily about hal in the MP group (period 1993-1994) against one-1hird in the CS group (period 1980-1992). The more recently effectuated donors mal therefore have sulfered essentially more ischemic darnage while all kidneys procured were preserved by MP. Kidneys in the historical control group on the contrary, may be less damaged while all were preserwed by CS. The separate analysis of NHB donor grafts with WIT longer than $45 \mathrm{~min}$, indeed showed that allnost half of the kidneys in the MP group suffered prolonged WIT and that even within this subgroup WIT evidently was increased (89.046.2 vs 59.7-4.3 min for MP vs CS group, respectively; $\mathrm{p}=0.002)$. In the prolonged ischemia group, the other donor and recipient data were more comparable in CS and MP groups thus minimising their influence. Although in the subgroup kidneys preserved by MP still sustained more warm ischemic damage than their CS counterparts, the short-1erm results were significantly improved by MP. This improvement was reflected by a better serum creatinine level at one 
month. The number of days before kidney function was life sustaining as well as the number of dialyses needed, did not differ among the groups, implying that MP did not effect the severity of DF once it had occurred. Using cyclosporin (CyA) in the immediate postransplant period is known to prolong the duration of DF [17]. The length of DF is importanit since prolonged DF was observed to be detrimental to graft survival in NHB donor kidney transplants (34). In the MP group, more patients received CyA ( 82 vs $63 \%, j=0.05$ ) which may oppose the positive action of perfusion preservation. The use of ATG ats induction immunosuppression and delayed introduction of $\mathrm{Cy} A$ until acceptable kidney function is established, could decrease the duration of DF [33].

\section{Conclusion}

NHB donor kidneys and their recipients need special attention with regard to preservation and postoperative treatment. High DF rates are of major concern and must be reduced to improve graft prognosis. The CS group in this analysis suffered less severe ischemic attacks than the MP group. Nevertheless, short-term outcome was at least equal in both groups; for kidneys that sustained prolonged ischemia, however, MP was superior to CS despite more unfavourable donor conditions. To verify these resilts and study the impact of MP on long-term outcome, a prospective study with matched controls is currently in process. We conclude that continuous cold perfusion is superior to simple cold storage as the preservation mode for NHB donor kidneys, especially after prolonged warm ischemic periods.

\section{Acknowledgement}

The authors thank the Eurotransplant Foundation and the collaborating transplant centers for their cooperation.

\section{References}

1. Matessen JG (1988) The stumed kidney: postischemic renal failure and ademine nucleotide homeostasis. In: Maessen JG. Evaluation of ischemic injury in donor kidneys: an experimental study. Wibro dissertatiedrukkerij, koermond, pp. $81-88$.

2. Daemen JHC, Kootstra $G$, Wijhen RMH, Yin M, Heineman E. Nonheart-beating donors: the Maastricht experience. In: Terasaki PI, Cecka JM (eds) Clinical Transplants 1994. UCLA Tissue Typing Laboratory, Los Angeles, pp $303-316$

3. Wijnen RMH, Booster MH, Stubenitsky BM* De Boer J, Heineman E, Kootstra G. Outcome of transplantation of non-heart-beating donor kidneys. Lancel 1995; 345: 1067-1070

4. Johnson RWG, Anderson M, Morley AR, Taylor RMR, Swinney J. Twenty-four-hour preservation of 
kidneys injured by prolonged warm ischemia. Transpinatation 1972;13:174-179

5. Booster MH, Winen RMH, Yin M, Tiebosch ATM, Heineman E, Matssen JG, Bunrman WA, Kurvers HAMM, Stubenitsky BM, Bonke H, Kootstra G. Enhanced resistance to the effects of normothermic ischemia in kidneys using pulsatile machine perfusion. Transplant Proc 1993; 25: 3006-3011

6. Kootstra G. Daemen JHC, Oomen APA. Categories of non-heart-beating donors. Transplant Proc 1995: 27: $2893-2894$

7. Heineman E, Daemen JHC, Kootstra G. Non-heari-beating donors: nethods and techniques. Transplant Proc 1995;27:2895-2897

8. Hoffman RM, Stratta RJ, D'Alessandro AM, Sollinger HW, Kalayoglu M, Pirsch JD, Southard IH, Belzer FO. Combined cold storage-perfusion preservation with a new synthetic perfsuate. Transplantation 1989 ; 47: $32-37$

9. Daemen JHC, Heineman E, Kootstra G. Viability assessment of non-heart-beating donor kidneys during machine preserwation. Transplant Proc 1995; 27: 2906:2909

10. Casavilla A, Ramirez C, Shapiro R, Shapiro R, Nghiem D, Miracle $K$, Bronsther O, Randhawa P, Broznick B, Fung JJ, Starzl TE. Experience with liver and kidney allografts from non-heart-beating donors. Transplantation 1995; 59: 197-203

11. Schlumpf $\mathbb{R}$, Candinas D, Zollinger A, Keusch $G$, Retsch $M$, Decurtins M, Largiader F. Kidney procurement from non-heartbeating donors: transplantation results. Transplant lni 1992; 5 (supp): 424-428

12. Valero $R$, Manalich M, Cabrer C, Salvador L, Garcia-Fages LC. Organ procurement from non-heartbeating donors by total body cooling. Transplant Proc 1993; 25:3091-3092

13. Castalao AM, Grinó JM, Gonźlez C, Franco E, GilVernet S, Andrés E, Serón D, Torras J, Moreso F, Alsina J. Update of our experience in Iong-term renal function of kidneys transplanted from non-heartbeating cadaver donors. Transplant Proc 1993; 25: 1513-1515

14. Varty K, Veitch PS, Morgan JDT, Kehinde EO, Donnelly PK, Bel PRF. Kidney retrieval from asystolic donors: a waluable and viable resource of additional organs. Br Med J 1994; 308: 575

15. Vromer MAM, Leumissen KML., Persijn GG, Kootstra G. Short-and long-terni resuits with adult nonhearl-beating donor kidneys. Transplant Proc 198:8; 20: 743-745

16. Troppmann C, Gilhngham KJ, Benedetti E, Stephen Almond P, Gruessner RWG, Najarian JS, Matas All. Delayed grafi function, acute rejection, and outcome after cadaver renal transplantation. Transplantation $1995 ; 59: 962-968$

17. Canafax DM, Torres A, Fryd DS, Heil JE, Strand MH, Ascher NL, Payne WD, Sutherland DER, Simmons RL, Najarian JS. The effects of delayed function on recipients of cadaver renal allogratts. Transplantation $1986 ; 41: 177-181$

18. Barry JM, Shively N, Hubent B, Hefty T, Norman D., Bennett WM. Significance of delayed graft function in cyclosporine-treated recipients of cadaver kidney transplants. Transplantation 1988; 45; 346-348

19. Wenkateswara Rao K, Andersen RC. Delayed graft function thas no detrimental effect on shont-term or long-term outcome of cadaveric renal transplantation. Transisplant Proc 1985; 17:2818-2820

20. Bama WD, Tang VYS, Maddux MS, Veremis SA, Pollak R, Mozes MF. Dellayed graft function following 
cadtorer renal transpiantation in the cyclosporine era: analysis of acute rejection and graft survival. Transplant Proce 1989:21:1276-1277

21. Howard RU, Pfaff WW, Brunson ME, Scomik JC, Ramos EL, Peterson JC, Fennell RS, Croker BP. Increased incidence of rejection in patients with delayed graft function. Clin Transplant 1994; 8:527-531

22. Campenter BJ, Rosenthal JT, Taylor RU, Hakala TR. The impact of acute tubular necrosis on graft outcome in patients receiving cyclosporine. Transplant Proc 1985; 17:1282-1283

23. Ploeg RJ, Van Bockel JH, Langendijk. PTH, Groenewegen M, Var der Woude FJ, Persijn GG, Thorogood 1, Hemans $J$. Effect of preservation solution on results of cadaveric kidney transplantation. Lancet 1992 340: $129-137$

24. MeAnulty JF, Ploeg RJ, Southard JH, Belzer FO. Successful five-day perfusion preservation of the canine kidney. Transplantation $1989 ; 47: 37-41$

25. Booster MH, Yin M, Stubenitsky BM, Kemerink GJ, Van Kroonenburgh MJPG, Heidendal GAK, Halders SGEA, Heineman E, Butrman WA, Wijnen RMH, Tiebosch ATM, Bonke H, Kootstra O. Beneficial effect of machine perfusion on the preservation of renal microcirculatory integrity in ischemically darnaged kidneys. Transplant Proc 1993;25:3012-3016

26. Barber WH, Deierhoi MH, Phillips MG, Diethelm AG. Preservation by pulsatile perfusion inaproves early renal allograft function. Transplant Proc 1988: 20:865-868

27. Light JA, Kowalski AE, Gage F, Callender CO, Sasaki TM. Immediate function and cost comparison berween ice storage and pulsatile preservation in kidney recipients at one hospital. Transplant Proc 1995; 27: $2962-2964$

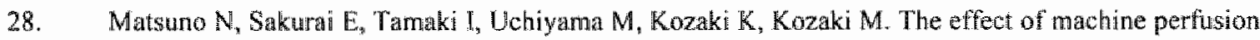
preservation versus cold storage on the function of kidneys from non-heart-beating donors. Transplantation 1994:57:293-294

29. Kozaki $M$, Matsuno $N$, Tamaki $T$, Tanaka $M$, Kono $K$, Ito $H$, Uchyama $M$. Tamaki $\mathbb{I}$, Sakurai $E_{\text {. }}$ Procurement of kidney grafts from nonmeart-beating donors. Transplant Proc 1991; 23: 2575-2578

30. OrlofTMS, Reed Al, Erturk E, Kruk RA, Paprocki SA, Cinbalo SC, Cerilli GJ. Nonlueartbanting cadaweric organ donation. Ann Surg 1994; 220:578;585

31. DAlessandro AM, Hoffmam RM, Knechtle SJ, Sollinger HW, Kalayogllu M, Pirsch JD, Belzer FO. Controlled non-heart-beating renal donation in the cyclosporine era. Abstract (O-30), 3rd International Congress of the Socjely for Organ Sharing: Paris, France, Jwly 17-19, 1995

32. Haltonn $\mathrm{P}$. Aprile M. Farewell $V$ for the Ontario Renal Transplant Research Group. Pactors influencing early renal function in cadaver kidney transplants. Transplantation 1988; 45:122-127

33. Zhou YC, Cecka JM. Effect of HLA mathing on renal transplant survival. In: Terasaki PI, Cecke JM (eds) Clinical Trinsplants 1993, UCLA Tissue Typing Laboratory "Los Angeles, 1994, pp.499-510

34. Vokoyama I, Uchida $K$, Kobayashi $T$, Tominaga $Y$, Orihara A, Takagi $H$. Effect of prolonged delayed graft function on long-term graft outcome in cadaveric kidney transplantation. Clin Transplant 1994; 8: $101 \cdot 106$ 
EFFECT OF MACHINE PERFUSION PRESERVATION ON DELAYED

GRAFT FUNCTION IN NON-HEART-BEATING DONOR KIDNEYS

- EARLY RESULTS -

JHC Daemen, B de Vries, APA Oomen, J DeMeester, G Kootstra

Transplant International 1997; 10: 317-322 


\section{Introduction}

Organs for transplantation procured from non-heart-beating (NHB) donors sustain a period of warm ischemia ance the blood stops circulating. Thig warm ischemic period leads to rapid loss of high energy metabolites, altered calcium metwbolism, and vascular blockage, which consequently damage the organs. Basic cell functions are disturbed and reactive oxygen species are generated when the blood flow is subsequently restored [37]. As a result, upon reperfusion organ function after transplantation may be impaired ar even lost. Transplanted NHB donor kidneys show high rates of delayed onset of function $[16,35,38]$. The impact of delayed function (DF) on the outcome of transplantation is negative and considered undesirable for both elinical and economical reasons.

Preservation by machine perfusion (MP) is thought to be advantageous for the preservation of ischemically damaged kidneys. [23] and for improving the immediate posttransplant graft function [39]. Experiments have confirmed this; in fact, MP preservation of kidneys damaged by warm ischemia has been shown to be superior to preservation by simple cold storage (CS). In a recent study, MP resulted in betier survival rates and improved preservation of the microcirculatory integrity [6,7].

In an attempt to improve the early posttransplant function and reduce the DF rate, we selected MP as the preferred method for kidney preservation in our NHB donor program. In this study, we evaluate the early posttransplant function of grafted NHB donor kidneys preserved by MP and compare the short-term results with those of matched heart-beating ( $\mathrm{HB})$ donor kidneys preserved by $\mathrm{CS}$.

\section{Patients and Methods}

NHB donor kidneys were procured from patients who had suffered irreversible cardiac arrest. Patients were considered potential donors if circulatory arrest lasted less than 30 min lexcluding the time of resuscitation), and cardiopulmonary resuscitation did not exceed 2 h. The donors were not older than 65 years of age and had no history of uncontrollable typertension, kidney disease, or malignancies other than nonmetastasising primary brain tumours. The donors had no signs of systemic infection or intravenous drug abuse. The kidneys were preserwed in-situ through a technique applying a femoral cooling catheter and large volumes of cold preservation solution, as soon as possible after death and consent for organ donation was obtained [20]. All kidneys were presenved by MP in Gambro PF-3B organ perfusion machines (Gambro, Lund, Sweden). University of Wisconsin (UW) solution for MP was used as the perfusate [5]. Flow was set to an initial perfusion pressure of $60 \mathrm{mmHg}$ and kept constant thereafter; the kidneys were perfused continuously until transplantation. Organs not procured locally, 
were initially preserved by $\mathrm{CS}$ and sent to our institution. Kidneys were offered by Eurotransplant and transplanted to patients at several transplantit centers according to the uniform Eurotransplant allocation policy.

As controls for each recipient of a NHB donor kidney, we selected wo recipients of $\mathrm{HB}$ donor kidneys from Eurotransplant files. This control group was stratified for transplant center to prevent bias due to differences in posttransplant management. To prevent bias due to the effect of different preserwation solutions, all HB donor kidneys were preserved by UW in simple CS. The controls were matched for the number of transplant (first, second, third), current level of panel reactive antibodies (PRA; $5 \%$ or less. $6 \%-85 \%$, or $>85 \%)$, number of HLA-DR mismatches $(0,1,2)$, donor age $(<10$ years difference), date of transplantation ( $<5$ years difference), and recipient age (15-50, over 50 years of age; table 1$)$. Transplant centers were approached for co-operation and data were collected by questionnaire.

Table 1. Matching criteria

- Same transplant center

- CS preservation by UW

- Number of transplant (1st, 2nd, 3rd)

- Current level PRA $(\leq 5 \%, 5-85 \%, \geq 86 \%)$

- HLA-DR mismatches $(0,1,2)$

- Donor age ( $+/ 210$ years)

- Date of transplantation ( $+1-5$ years)

- Recipient age ( $5-50,>50$ years)

${ }^{a} \mathrm{CS}=$ cold storage, UW-University of Wisconsin preservation solution, PRA=panel of reactive antibodies, HLA=human lymphocyte antigens

Relevant donor and recipient characteristics were anallysed to ascertain the efficiency of matching. Early posttransplant function was classifjed as (1) immediate function (IF), i.e., life-sustaining renall function without any postransplant dialysils; (2) delayed function (DF), i.e., ultimately life-sustaining renal 
function but at least one postraneplant dialysis treament rectssary; or (3) primary nonfunction (PNF), i.e., renal function failed with continuing dialysis. Renal function was estimated at 1,3 , and 6 months postransplant by measuring serum creatinine levels. Grafts with DF were analysed further. The number of postoperative days until the patient was withou dialysis and number of dialysis sessions within this period were registered. Rejection episodes in the first 3 months were defined as the rumber of rejection treatments implemented, whether proven by biopsy or not.

Finally, the outcome of renal grafts from NHB donors who died after an unsuccessful resuscitation attenipt (category 2 NHB donorg) was compared to that of renal grafts from NHB donors who sustained irreversible cardiac arrest after intentional withdrawal of hife-suppont treatment (category $3 \mathrm{NHB}$ donors). Categorisation is described in detail el wewhere [24].

The results are given as percentages or as mean \pm SD. The differences between the groups were calculated with the Pearson chi-square lest and Yates' correction for discrete variables. The MannWhitney U-test for unrelated continuous variables, where appropriate. P values less than 0.05 were considered statistically significant.

\section{Results}

Between August 1993 and July 1995, 39 NHB donor kidneys were preserved by MP at the Uniwersity Hospital Maastricht and subsequently transplanted within the Eurotransplant organisation. Two grafts that were successfully transplanted outside this area were not avallable for matching purposes and excludted from the study [29]. Thus, 37 kidneys with a followiup period of at least 6 months (mean 13स7), were included in the NHB group. Consequently, $74 \mathrm{HB}$ controls were matched and selected for comparison. The donor data are given in table 2 . The main causes of death among the NHB donors were myocardial infarction (35\%), cerbral bleeding (30\%), and cerebral trauma (19\%). $\mathrm{HB}$ donor death was caused mainly by cerebral bleeding $(58 \%)$ and cerebral trauma $(34 \% ; p<0.001)$. Seventeen kidneys from category 2 and 17 from category 3 NHB dohos were transplanted. Three (8\%) kidneys were procured from NHB donors who had sustained irreversible cardiac arrest after brain death had been diagnosed (caregory 4 NHB donors). NHB donors died either in the emergency room (41\%) or Intensive Care Unit $(1 \mathrm{CU} ; 59 \%)$, so that none of the in-situ preservation procedures took place in the operating room under controlled circumstances [14]. 
Table 2. Donor characteristics ${ }^{3}$

\begin{tabular}{|c|c|c|c|}
\hline & NHB donors & $\mathrm{HB}$ donors & p-walue \\
\hline Age (years) & $45 \pm 16$ & $41+15$ & 0.23 \\
\hline Gender (M:F) & $16: 21$ & $51: 23$ & 0.000 \\
\hline Serum oreatinine (mollo) & $111 \pm 58$ & $87 \pm 31$ & 0,009 \\
\hline Diuresis (mL/tast $24 \mathrm{~h})^{b}$ & $3319 \pm 2493$ & $5337+3291$ & 0.003 \\
\hline WIT (min) & $49 \pm 34$ & $0 \pm 0$ & $<0.001$ \\
\hline
\end{tabular}

Recipient characteristics are given in table 3. There were no differences between the $\mathrm{NHB}$ and $\mathrm{HB}$ donor groups for blood type, original renal disease, type of dialysis (haemodialysis in $70 \%$ vs $64 \%, \mathrm{p}=0.83$ ), or duration of pretransplant dialysis $(36+39$ vs $45+43$ months, $p=0.32)$. Immunosuppressive protocols were similar for both groups. Cyclosporin was used for $32(86 \%)$ of the NHB donor kidneys, and for 68 $(92 \%)$ of the $\mathrm{HB}$ donor kidneys $(\mathrm{p}=0.93)$. It was introduced preoperatively or immediately postoperatively in $23(72 \%)$ and $47(68 \%)$ cases, respectively. Recipients of NHB donor grafts received cyclosporin plus steroids 14 times (38\%) and triple immunosuppression (cyclosporin, azathioprine, and steroids) 17 times (46\%). These regimens were prescribed in $46(62 \%)$ and $18(24 \%)$ recipients in the HB donor group, respectively ( $\mathrm{p}=0.08$ ). Induction protocols using OKT3, ATG/ALG, or other agents for rejection prophylaxis were used for $8(22 \%)$ NHB donor kidneys and for $15(20 \%)$ HB donor kidneys $(\mathrm{p}=0.56)$.

Early postransplant function of NHB donor kidneys was significantly different from that of HB donor kidneys (table 4). Renal function was impaired but recovered within 6 months (table 5). As a result of the high PNF rate, the survival of NHB donor grafts was reduced. Additionally, wo grafts fiated within the first month due to untreatable acute rejection. Thus, graft survival at 6 months was $72 \%$ for NHB donor grafts and $90 \%$ for $H B$ dono" grafts. No patients died within 6 moniths posttransplant in either group. 
Table 3. Recipient characteristics ${ }^{3}$

\begin{tabular}{llll}
\hline & NHB donors & HB donors & p-value \\
\hline Age (years) & $48 \pm 14$ & $47 \pm 12$ & 0.36 \\
Gender (M:D) & $24: 13$ & $47: 27$ & 0.89 \\
Retransplant & $4(11 \%)$ & $15(20 \%)$ & 0.37 \\
Current PRA $>5 \%$ & $6(17 \%)$ & $12(16 \%)$ & 0.87 \\
HLA.DR mismatches & $0.5 \pm 0.5$ & $0.4 \pm 0.5$ & 0.52 \\
CTT (h) & $30 \pm 6$ & $25 \pm 9$ & 0.001 \\
\hline
\end{tabular}

\footnotetext{
${ }^{a}$ Values in mean $\mathrm{ESD}$ or numbers $(\%)$
}

A comparison of transplants with kidneys from category $2(\mathrm{n}=17)$ and category $3(\mathrm{n}=17)$ NHB donors, revealed no differences in early posttransplant outcome or renal function, despite increased age ( $52 \pm 14$ vs $41 \pm 13$ years, respectively; $\mathrm{p}=0.01)$, increased serum creatinine $(133 \pm 52$ vs $93 \pm 62 \mu \mathrm{mol} L$. respectively; $p=0.003$ ), and longer wamn ischemia time (WTT; $79 \pm 26$ vs $21 \pm 11$ min, respectively; p $<0.001$ ) for category 2 NHB donors. Five grafts (29\%) from the category 2 NHB donors and one from the calegory 3 NHB donors had PNF. The difference, however, was not statistically significant $(\mathrm{p}=0.12)$.

\section{Discussion}

The success of transplantation has made it the treatment of choice for patients with end-stage renal disease. Yet, the increasing demand for kidneys has created a gap between the organs available and the organs needed. It renal transplantation, NHB donors are valuable in reducing this organ shortage and the wating lists, and organ procurement from these donors is gaining more attention. However, NHB Honors sustain cardiac arrest, and wam ischemia subsequently damages the kidneys. This, in turn, cause acute tubular necrosis (ATN) and impared clinical function after grafting. Thus, there is often no immediate life-supporting function and dialysis must be continued until the transplanted kidney has recovered and reganed its function.

There is much controversy about the effect of DF on graft survival $[4,8,9,36]$. It is thought to increase the incidence of acute rejection [22] and 10 reduce graft survival. Without rejection, graft survival may not be influenced by DF [34]. This suggests that, while ischemic and immunologic factors may 
Table 4. Early posttranspiant function

\begin{tabular}{llll}
\hline & NHB donors & HB donors & p-value \\
\hline \multicolumn{1}{c}{ Immediate function } & $12(32 \%)$ & $44(59 \%)$ & \\
Delayed function & $18(49 \%)$ & $25(34 \%)$ & 0.02 \\
Primary nonfunction & $7(19 \%)$ & $5(7 \%)$ & \\
\hline & & & \\
\hline & $1511 \pm 2341$ & $1911 \pm 2392$ & 0.09 \\
Dituresis posttransplant (mL/1 st 24 h) & $18 \pm 10$ & $14 \pm 11$ & 0.82 \\
Dialysen DF (days) & $6 \pm 4$ & $33 \pm 32$ & 0.74 \\
Hospital stay (days) & $33 \pm 17$ & $0.7 \pm 1.0$ & 0.88 \\
Rejection episades (number/1 st 3 mo) & $0.6 \pm 0.9$ & & \\
\hline
\end{tabular}

Values in numbers $(\%)$ or mean $\pm \mathrm{SD}$.

Table 5. Serum creatinine of functioning kidneys

\begin{tabular}{clll}
\hline Months posttransplant & NHB donors & HB donors & p-wallue \\
\hline 1 & $292 \pm 184(26)^{\text {b }}$ & $185 \pm 114(61)$ & 0.01 \\
3 & $217 \pm 126(27)$ & $152 \pm 52(62)$ & 0.02 \\
6 & $196 \pm 117(24)$ & $152 \pm 69(63)$ & 0.22 \\
lowest & $155 \pm 64$ & $124 \pm 42$ & 0.04 \\
\hline
\end{tabular}

\footnotetext{
a Serum creatinine in $\mu \mathrm{mol} / \mathrm{L}$, values in mean $\pm \mathrm{SD}$.
}

${ }^{b}$ Number of evaluated grafts. 
both result in ATN and DF of the transplanted kidney. DF witl an immunologic component will reduce graft survival [18]. Although it may have multiple causes, DF is a serious posttransplant complication for a number of reasons. Posttramplant managenent is more difficult, symptoms of early rejection are disguised, and costs are increased due to longer hospital stay and contimued dialysis. Furthermore, the prolonged dependence on dialysis and initial fatlure of the transplant are frustrating to both recipient and physician. Therefore, DF is a major concern in kidney ransplantation, especially with NHB donor kidneys.

It has been reported that preservation by MP reduces DF rates and increases the prompt function of renal grafts $[1,17,25,28]$. Moreower, MP with the synthetic UW solution for MP (Belzer's perfusate) has been found to be superior to MP with plasma based perfusate [2]. Nevertheless, the effect of MP on graft Survival remains controversial [25,30]. Because MP preservation is labour-intensive, logistically demanding, and costly, and because CS solutions are becoming increasingly safe and effective, most transplant centers have abolished the use of preservation machnes. Nowadays organ preservation by simple CS is the standard. Kidney preservation by MP may still be preferable for prolonged preservation times [27] and for preservation of ischemically damaged kidmeys. However, the observed prolonged cold ischemia time (CIT) in the NHB donor group, and thus in the MP preserved group, should be avoided, as it is known to lead to DF [10]. Ht is also reported to have a detrimental effect on graft survival in combination with DF, HLA-DR mismatch, and acute rejection [1 1]. In the case of organs already damaged by warm ischemia, as in NHB donor kidneys, prolonged hypothermic ischemia has an additional negative effect on transplant outcome, even if kidneys are preserved by MP. Therefore, preservation time should be kept to a minimun.

MP For preserving NHB donor kidneys has been reported to be more advaniageous than CS in a study in which each kidney was compared with its own contralateral as a control [26]. The procedures, however, were fully controlled and the WIT was extremely short. The excellent transplant results with NHB donor kidneys reported by $D^{\prime}$ Allessandro et al. [14], and Orloff et al. [31] are at least partially attributable to preservation by MP.

Since no group of NHB donors was avalable as a control group for this study, the impact of MP on transplantation results with NHB donor kidneys had to be compared to HB donor controls. The groups were adequately matched and were comparable. Increased donor serum creatinine and decreased diuresis are typical for NHB donors and reflet the hemodynamically unstable agonal phase. MP could not correct for the differences in early posttransplant function between NHB and matched HB donor grafts. 
Although DF still occurred significantly more often in the NHB MP grots, our results with MP in this study suggest a reduction of DF in comparison to the previously reported DF rates of $60 \%-90 \%$ with NHB grafts preserved by CS $[15,16,38]$. Others report considerable lower DF rates with CS; however, donors were different with respect to age, cause of death, CIT and WIT [33]. Excellent results with DF: rates of merely $19 \%-22 \%$ have been obtained with categon $3 \mathrm{NHB}$ donors and preservation by $\mathrm{MP}$ [14,31]. In those series, however, many viable grafts have been lost due to the extreme selection.

Whenever DF occurted, the severity did not differ among the groups. This is reflectad in the equal duration of postoperative dialysis and the number of dialyses needed After initial impainment due to more DF in the NHB donor group, renal function mecovered, and within 6 months was equal for both groups. Similarly, the lowest serum creatinine reported in the NHB donor group (155+64 $\mu$ molL), as an indication of potential renal function, was higher than the lowest level for the HB donor group, but acceptable. The higher DF rate did not result in more acute rejection episodes in the NHB donor group, confirming the suggestion that DF based on ischemia does not predispose the patient to acute rejection. Although there was a slight tendency to treat recipients in the NHB donor group with triple immunosuppressive therapy more often, induction therapy was equally employed. To prevent cyclosporin nephrotoxicity in the early posttransplant period, especially in recipients of $\mathrm{NHB}$ donor kidneys with a high risk of DF, induction therapy with $A T G, A L G$, or OKT3 and sequential delayed introduction of cyclosporin may be beneficial [19].

The PNE rate of $19 \%$ for WHB donor kidneys in our study is unacceptable. Analysis of the contralateral kidneys of the grafts with PNF, revealed one pair failing and three kidneys with not transplanted contralaterals. Excessive ischemia might have played a role in the failure of these fve kidneys. The other Wo PNF grafts had functioning contralaterals. This high PNF fate also had a major impact on graft survival in the NHB donor group, which was reduced considerably. When considering functioning grafts only, the 6 month graft survival was similar $(92 \%$ and $97 \%$ for both groups. The increased failure rate of NHB donor kidneys underlines the importance of parameters that maty give an indication of the warm ischemic damage sustained and the expected postranspiant function. Especially in category 2 NHB donors warm ischemic damage is unknown and may vary considerably. An adequate viability lest might indicate whether posttransplant tubular necrosis in a graft is reversible; it migh thus be of holp in discarding nonviable kidneys [13].

In the present study, the beneficial effect of MP on warm ischemic damage in NHB donor kidneys was demonstrated by the similar results obtained with grafts from category 2 and cafogory 3 NHB donors. 
Despite the alder age of, and increased WIT for, category 2 NHB donors, transplanted kidneys functioned as well as the obviously less damaged kidneys from category $3 \mathrm{NHB}$ donors. Apparently, MP is especially beneficial after prolonged warm ischemia, confirming earlier suggestions [12,32]. In aiddition to the direct effect on the organss, MP provides access to the organ for graft evaluation and intervention during preservation. Although proposed "rescue agents" did not affect the transplant outcome of canine kidneys damaged by prolonged trypothermia [32], the effect of such agents on posttransplant function of NHB donor kidneys is worth evaluating. Furthermore, in ischemically damaged kidneys, reperfusion injury might be reduced by preventing free oxygen radical formation during preservation $[3,21]$.

From this: study, we conclude that early postransplant function of NHB donor kidneys preserved by MP is impaired wersus that of matched HB donor controls preserved by CS. Still, the results suggest a beneficial effect of MP on NHB donor kidneys as the DF rates are lower than those reported in NHB donor kidneys preserved by CS. Moreover, the transplant outcome is similar for categony 2 and category 3 NHB donows. Apparently, MP does not repair NHB donor kidneys but merely minimises additional danage. However, our study group was rather smali, and our findings need to be confrmed in the longterm. Since NFB donor kidneys are already ischemically damaged, further insults that threaten graft function, i.e., prolonged CIT and cyclosporin nephrotoxicity, should be avoided to obtain optimal transplant results. MP plays a key role in improving the preservation of ischemically damaged organs and in developing viability tests that will prevent transplantation of nonviable kidneys. Although MP is useful for preservation of $N H B$ donor kidneys, in itself it is not sufficient to obtain optimal transplant restults.

\section{Acknowledgenments}

The authors think Liliane Streeder for her assistance in the matching procedure. We also thank the following transplant centres for their co-operation:

S. Surachno, M. van Aart (Amsterdam); G. Verpooten, G. Van Beeumen (Antwerp); G. Offermann (Berlin); F. van Zantvoort (Bremen); đ. Squiflet, P. Vanormelingen, Y. Prison (Brussels); K. Albrecht, F. Eigler (Essen); H. Kachel, W. Schoeppe (Frankfurt); A. Tegzess (Groningen); B. Hollenrieder (Hamburg); F. van der Woude (Leiden); J. van Hooff, M. Christians (Maastricht); R. Koene, H. van Wezel (Nijnegen); I. Hauser, G. Schott, M. Schreiber (Numberg); R. Hené (Utrecht). 


\section{References}

1. Barber WH, Deierhoi MH, Phillips MG, Diethelm AG. Preservation by pulstalle perfusion improves carty renal allograft function. Transplant Proc 1988: 20: 865-868

2. Barber WH, Laskow DA, Deiehoi MH, Poplawski SC, Diethelm AG. Comparison of simple hypothermic storage, pulsatile perfusion with Belzers gluconate-albumin solution, and pulsatile pertusion with UW solution for renal allograft preservation. Transplant Proc 1991; 23:2394-2395

3. Baron P, Gomez-Marin O, Casas C, Heil J, Will N, Condie R, Burke B, Najarian JS, Suthertand DER. Renal preservation after warm ischernia using oxygen free radical scavengers to prevent reperfusion injury. J Surg Research 1991; $51: 60-65$

4. Barry JM Shively N, Hubert B, Hefty T, Noman Df, Bernett WM. Significance of detayed graft function in eyclosporine-treated recipients of cadaver kidney transplants. Transplaniation 1988:45:346-348

5. Belzer FO, Glass NR, Sollinger HW, Hothanan RM, Southard JH. A new perfusate for kidney preservation. Transplantation 1982; 33: 322-323

6. Booster MH, Wijnen RMH, Yin M, Tiebosch ATM, Heineman E, Maessen JG, Buurman WA, Kunets HAM, Stubenitsky BM. Bonke H, Kootstra G. Enhanced resistance to the effects of nomothermic ischemia in kidneys using pulsatille machine perfusion. Transplant Proc 1993; 25:3006-3011

7. Booster MH, Yin M, Stubenitsky BM, Kemerink GJ, Kroonenburgh MJPG van, Heidendal GAK. Halders SGEA, Heineman E, Bumrman WA, Wijnen RMH, Tiebosch ATM, Bonke H, Kootstra G. Beneficial effect of machine perfusion on the preservation of renal microcirculatory integrity in ischemically damaged kidmeys. Transplant Proe 1993; 25: 3012-3016

8. Canafax DM, Torres A, Fryd DS, Heil JE, Strand MH., Ascher NL, Payne WD, Sutherland DER, Simmons RL, Najarian JS. The effects of delayed function on recipients of cadaver renal allografts. Transplantation $1986 ; 41: 177-181$

9. Carpenter BJ, Rosenthal JT, Taylor RJ, Hakala TR. The impact of acute tubular necrosis on graft otticonte in patients receiving cyclosporine. Transplant Proc 1985; 17:1282-1283

10. Cecka JM, Cho YW, Terasaki PI. Analyses of the UNOS scientific retal transplant registry at three years - early events affecting transplant success. Transplantation 1992;53:59-64

11. Connolly IK, Dyer PA, Martin S, Parrot NR, Pearson RC, Johttson RWG. Importance of minimizing HLA-DR mismatch and cold preservation time in cadaveric renal preservation. Transpinatation 1996; 61: 709.714

12. Daemen JHC, Wit RJ de, Bronkhorst MWGA, Marcar ML, Yin M. Heinenan E, Kootstra G. Short-term outcome of kidney transplants from non-heart-beat ing donors afier preservation by machine perfusion. Transpl Int 1996; 9 (suppl): 76-80

13. Daemen JHC, Oomen APA, Janssen MA, Schoo: $\mathrm{L}$ van de, Kreel BK van, Heineman E, Kootstra $\mathrm{C}$. Glutathione S-transferase as predictor of functional outcome in transplantation of machine preserved nonheart-beating donor kidneys. Transplantation 1997; 63: $89-93$

14. D'Alessandro AM, Hoffmann RM, Belzer FO. Non-heant-beating donors: one response to the organ shortage. Transplant Rev 1995; 9: 168-176 
13. Durlop P. Vary $\mathrm{K}$, Veich PS, Nicholson ML, Bell PRF. Non-heart-beating donors: the Leicester experience. Transplan Proc 1995; 27: 2940-2941

16. Gonzalez Segura C, Castelao AM, Torras 1, Gil.Vernet S, Lopez Costea MA. Riera L, Franco E, Fulladosa $X_{1}$ Grino $M_{3}$ Alsina J. Long-term follow up of transplanted nor-heart-beating donor kidneys. Transplant Proc 1995: 27: 2948-2950

17. Hallown $P$, Aprile $M$. A randomized prospective trial of cold storage versus pulsatile perfusion for cadaver kidney prescrvation. Transplantation $1987 ; 43,827-832$

18. Halloran P, Aprile M, Farewell V. Fackors influencing early renal function in cadaver kidney transplants. Transplantution 1988; $45: 122-127$

19. Hariharan $\$$, Alexander JW, Schroeder TJ, First MR. Outcome of cadaveric renal transplantation by induction treatment in the cyclosponine era. Clin Transplantation 1996; 10: 186-190

20. Heineman E, Daemen JHC, Kootstra $G$. Non-heart-beating donors. methods and techniques. Transplant Proc 1995; 27: 2895-2897

21. Hoshino T, Maly WR, Bulkley GB, Williams GM. Ablation of free radical mediated reperfusion injury for the salwage of kidneys taken from non-heartbeating donors. Transplantation 1988; 45: 284-289

22. Howard RJ, Pfaff WW, Brunson ME, Scomik JC, Ramos EL, Peterson IC, Fennell RS, Croker BP. Increased incidence of rejection in patients with delayed graft function. Clin Transplantation 1994; 8:527531

23. Johnson RWG, Anderson M, Morley AR, Taylor RMR, Swinney J. Twenfyw four hour preservation of kidneys injured by prolonged warm ischemia. Transplantation 1972; 13: 174-179

24. Kootstra G, Daemen JHC, Oomen APA. Categories of non-heart-beating donors. Transplant Proc 1995; 27: $2893-2894$

25. Koyana H., Cecka JM, Terasaki PI. A comparison of cadaver donor kidney storage methods: pump perfusion and cold storage solutions. Clim Transplantation 1993; 7:199-205

26. Matsuno N, Sakurai E, Tamaki I, Uchiyama $M$, Kozaki K, Kozaki $M$. The effect of machine pertusion presenvation versus cold storage on the function of kidneys from non-heart-beating donors. Transplanation 1994; $57: 293-294$

27. MGAubly JF, Ploeg RJ, Southard JH, Belzer FO. Successful five-day perfusion preservation of the canine kidney. Transplantation 1989; 47: 37-41

28. Merion RM, On HK, Poit FK, Toledo-Pereyra LH, Turcotie JG. A prospective controlled trial of coldshorage versus machine-perfusion preservation in cadaveric renal transplantation. Transplantation 1990; 50: $230-233$

29. Naqui A, Zafar N, Hashmi A, Akhtar F, Hussain Z, Rizwi A. Two cadaveric renal transplants in Pakistan from non-heart-beating donors from Maastricht. Lancet $1996 ; 347: 477-478$

30. Opelz $\mathrm{G}_{3}$ Wujcialk T. Comparative analysis of kidney preserwation methods. Transplant Proc 1996; 28 : 87.90

31. Orlof MS, Reed Al, Enturk E. Kruk RA, Paprocki SA, Cimbalo SC, Cerilli GJ. Nonheartbeating cadaweric organ donation. Ann Surgery 1994; 220:578-585 
32. Ploeg R, Vreugdenhil P, Goossens D, McAnulty IF, Southard HH, Belzer FO. Eftect of phamacologic agents on the function of the hypothermically preserwed dog kidney during nomothemic repertusion. Surgery $1988 ; 103: 676-683$

33. Schlumpf $R$, Weber $M$, Weinreich $T, K$ Lotz H, Zollinger A, Candinas D. Transplantation of Kidneys from mon-heart-beating donors: an update. Transplant Proc 1995; 27: 2942-2944

34. Troppmann C, Gillngham KU, Benedetti E, Almond PS, Gruessner RWG, Najarian IS, Matas AJ. Delayed graft function, acute rejection, and outcome after cadaver renal transplaniation. Transplantation 1995:59: $962-968$

35. Varty $\mathrm{K}$, Veitch PS, Morgan JDT, Bell PRF, Kidney retrieval from asystolic donors: a wallable and wiable source of additional organs. Br J Surg 1994: 81 : 1459-1460

36. Venkateswara Rao K, Andersen RC. Delayed graft function has no detrimental effect on short-tern or long-term outcome of cadaveric renal transplantation. Transplant Proc 1985; 17:2818-2820

37. Weinberg IM. The cell biology of ischemic renal injury. Kiclney Int 1991; 39:476-500

38. Wijnen RMH, Booster MH, Stubenitsky BM, Boer J de, Heineman E, Kootstra G. Outcome of transplantation of non-heart-beating donor kidneys. Lancet 1995; 345: 1067×1070

39. Zhou YC, Cecka JM. Effect of HLA matching on renal transplant survival. In: Terasaki PI, Cecka JM (eds) Clinical Transplants 1993, UCLA Tissue Typing Laboratory, Los Angeles, 1994, pp 499-510 


\title{
VIABILITY TESTING DURING ORGAN PRESERVATION
}

\author{
- an introduction -
}

from: Kidney Transplantation from Non-Heart-Beating Donors

JHC Daemen, RJ de Wit, E Heineman, G Kootstra

Transplantation Reviews 1995; 9: 159-167 


\section{Viabullaty}

In order to expand the non-heart-beang (NHB) donor pool safely, it is very imponant to be able to distinguish whether a graft is going to have primary nonfunction (PNF) upon transplantation or not. Therefore, it is crucial to be able to predict whether a kidney is viable or not because, especially in the NHB donor, kidneys might have sustained substantial wam ischemia of unknown sewerity and duration. Ever since kidney transplantation was implemented, efforts have been made to predict the viability of the organ before transplantation. Reports in the literature on this subject have decreased in the last decade, probably because of the almost exclusive use of heart-beating (HB) donors and the increasing safety of the preservation methods. An interesting and complicating factor as well, is the fact that even if one would be able to quantify the ischemic injury after procurement, or just before implantation, there still is an unknowin injury at reperfusion to come. Therefore, positransplant kidney function is the outcome of several cumullative ischemic attacks to the kidney.

\section{Nucleotides}

Cell anoxia causes inhibition of the oxidative phosphorylation, thus a fall in adenine nucleotide content. Although adenine tri-phosphate (ATP) content of the renal cortex and total adenine mucleotide (TAN) content could be correlated to survival of the kidneys [1], this cortelation does not exist after pre-existing normothermic ischemia [2]. TAN content decreased with reduced viability but was, along with warm ischemia, influenced by the duration of cold preservation [3]. Also, when restoring TAN levels during preservation of ischemically damaged kidneys, survival was not improved [4], proving that nucleotide levels alone cannot predict organ viability. Hypoxanthine as a degradation product (DP) of aclenine nucleotide catabolism estimated in the washmout perfusate of ischemic kidneys, was brought forward as a useful parameter for assessment of ischemic damage in an experimental seting [5]. Although Maessen et al. [6] found that the ratio of DP to TAN, assessed immediately after procurentent of HB donor kidneys, was strongly correlated to the sustamed period of wam ischemia, i.e. wam ischemic time (WIT), it was stressed that this assessment of WIT should be regarded as a parameter of safely margins for viability rather than as a straght predictor of organ viability. An in-situ flushout, as is done in the clinical NHB donor procedure, will probably wash out the DP thus making the DPRTAN ratio useless in estimating this salfety margin.

Intracellular ${ }^{31}$ phosphonus metaboltes can be assessed during cold storage (CS) by magnetic resonance spectroscopy (31P-MRS), a non-invasive and non-destructive method. The subsequent degradation of ATP to adenine di-phosphate and eventually adenine mono-phosphate (AMP) releases phosphorus atoms 
at cach step. The phosphorus mono esters (PME) and inorganic phosphorus (Pi) concentrations un renal tissue measured by 31P-MRS, correspond to the concentrations of AMP and free phosphorus [7]. Bretan et al. [8] found a strong correlation between the PMEPI ratio and warn and cold ischemic damage lin rat kidneys, objectified by electron microscopic exaluation. These results were confirmed in canime and rat ransplant models showing that the PME/Pi ratio is a sensitive indicator of a compromised sumergy conversion system due to hypoxia and ischemia $[9,10]$. In human kidneys preserved by $\mathrm{Cs}$, lower PME/Pi ratios were associated with prolonged postranspland dystunction of the grafts due lo acute tubular necrosis. Pretransplant sensitivity of $75 \%$ and specificity of $87 \%$ were reported in predicting delayed function (DF) by using a PME/Pi ratio=0.5 as cut off point [11]. However none of these kidneys sustained essential warm ischemia.

\section{Enzymes}

The lack of oxygen eventually alters cell membrane integrity, which causes lysosomal enzymes to leak into the interstitial space. Reports on using these lysosomal enzymes in estimating ischemic damage are many. Lactate dehydrogenase ( $\mathrm{LDH})$ is most often mentioned and directly related to ischemia and postischemic function [12]. More recently, the specific LDH4 and LDH5 isoenzymes were said to present a more sensitive parameter for hypoxic tissue damage [13]. In nonischemic kidneys, LDH (as was aspartate aminotransferase, AST) was found also to indicate preservation damage [14]. Being both lysosomal enzymes of the proximal tubular cell, $N$-acefyl-B-D-glucosaminidase failed to predict kidney function in canine renal transplantation [15], while ligandin was able to predict kidney function prior to transplantation in humans [16]. Most of these tests are done by estimating enzyme activity in the perfusate while the kidneys were conthuously being perfused in a perfusion machine. Determination of byaluronic acid levells in the washout efmwent of CS kidneys performed just prior to implantation of the kidney failed to predict early graft function, unlike it did in liver transplants [1.7].

Another way to estimate the viability of kidney grafts is measuring the overall impairment of metabolic capacity of the renal tubular cells. One way of determinuing this capacity is by means of the principle that tetrazolium salts are rapidly reduced to formazan by intact mitochondrial reduction-oxidation enzymes; thus causing a detectable colour change. Smith et al. 18] and Yin et al. [19] described melhods and found a strong correlation between ischemia times at different temperatures and the ability of renal cortex to reduce tetrazolium salts. Alhough proposed, trials wih human material were never reported. 


\section{Lectrolytes}

Throtghth the sodium potassium pump (NaK-pump) renal tubular cells can maintain the sodium (Na) and potassium $\left(K^{\prime}\right)$ gradients across their cell membrane. Since the NaK-pump is ATP dependent and during anoxix ATP levels rapidly decline, ischemia is hampering the function of the NaK-pump. The cell is unable to keep up its intracellular composition thus looses its integrity, swells, and finally the cell membrane ruptures. As a result $\mathrm{K}^{*}$ is leaking into the interstitial space. By measuring the $\mathrm{K} / \mathrm{Na}$-ratio in human kidney tissue biopsies Sells ef al. [20] were able to predict posttransplant renal function well in a retrospective analysis. By measuring the $\mathrm{K} / \mathrm{Na}$-ratio in the perfusate of dog kidneys preserved for 6 days, an additional parameter for parenchymal viability was found [21].

Recently the use of a biochemical multisensor element for estimating extracellular ion-shifts was reponted [22]. By monitoring electrolyte activities at the organ surface, the authors were able to conrelate posttransplant function (i.e., nonfunction vs. delayed function) to pretransplant $K^{+}$activities in human cadaveric kidney transplants [23]. Again, these kidneys did not sustain warn ischemia.

\section{Functional}

As a reaction to the ischemic insult the vascular resistance within the kidney is increased. The precise mechanism is still unclear but it might be the result of nervous stimulation, the lacal release of vasoconstrictive agents, the loss in ability of the renal endothellum to release endothelium derived relaxing factor (EDRF, identified as nitric oxide) [24,25], and/or vascular blockage due to swelling of endothelial and perivascular cells and congestion of erythrocytes [26,27]. By recording flow and perfusion pressure during preservation in a perfusion machine, this increased intrarenal vascular resistance (IRR) can be estimated and function as a parameter for perfusion and ischemic damage [28]. In both experimental and clinical studies, increasing IRR patterns during machine perfusion (MP), were related to impaired posttransplant kidney function. Perfusion characteristics have been purported as a method to safely expand the donor pool with donors regarded as marginal in both HB and NHB donor programs [29-31]. High IRR and low perfusion flow are regarded as parameters to discard kianeys although different cut - off points were reported. As mentioned before, in the Maastricht NHB donor program we also discard NHB donor kidneys based on their perfusion characteristics [32]. Although identifying non-functionimg kidneys seems possible, distinguishing between delayed and immediate functioning grafts upon transplantation, might be difficult by these parameters.

Another method for testing the viability of the organs during MP could be by perfusian techniques. A 
washout technique with radioactive Xenon- 133 , reveals the redistribution of renal flow through the different compartments of the kidney; reduction of cortical fow is correlated to ischemic injury to the kidney [33]. Perfusing the kidney with technetium labelled hexamethyl propylene amine oxime (TcHMPAO) and scintigraphic imaging will visualise perfusion defects. Thus these parameters might be useful in predicting renal damage and postransplant viability [34]. No clinical use has been reported yet.

A possible method was recently suggested by using tandem scanning confocal microscopy (TSCM). This form of intravital microscopy enabled Andrews et al. [35] to identify in a rat model ischemic damage invivo. Obserwing rat kidneys preserved by CS using this technique provided artifact-free images of the villous brush-border and tubular lumen. In this way it was possible to follow up the condition of the preserved kidney in a time course up to $72 \mathrm{~h}$ of CS preservation [36]. However, the hypothesis that by this method one would be able to differentiate nonviable from viable kidneys in human transplantation certainly needs further investigation.

Although several methods have been proposed to assess the ischemic damage of kidneys for transplantation, few have been studied in warm ischernia as in NHB organ donation. So far, none have found broad clinical use in predicting renal transplant outcome. The most reliable factor predicting viability is the duration the ischemic period the organ suffered, including both normothemic and hypothermic ischemia. However, even with known total ischemia time predicting transplant outcome is hazardous as posttransplant function is the result of many factors. In NHB donation, as all organs are ischemically damaged, a useful viability test, i.e., a parameter to assess ischemic damage is of utmost importance. Anyway, the ultimate viability test still is transplanting the organ and assessing its function.

\section{References:}

1. Caman KC. The prediction of organ viability - an hypothesis. Cryobiology 1974; $11 ; 1-6$

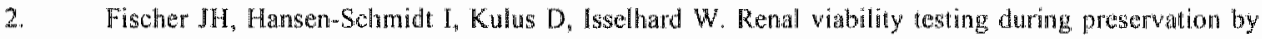
metabolic parameters. In: Pegg DE, Jacobsen IA, Halasz NA (eds). Preservation; Basic and Applied Aspects. Lancester, UK, MTP Press, 1982: 139-145

3. Southard 月H, Senzigg KA, Hoffmann RM, Belzer FO. Energy metabolism in kidneys stored by simple hypothermia. Transplantant Proc 1977; 9: 1535-1539

4. Pegg DE, Foreman J, Rolles K. Metabolism during preservation and viability of ischemically injured canine kidneys. Transplantation 1984; $38: 78-81$

5. Buhl MR, Kemp G, Kemp E. Hypoxanthine excretion during preservation of rabbit kidneys for 
transplantation. Trangplantation 1976:21:460-467

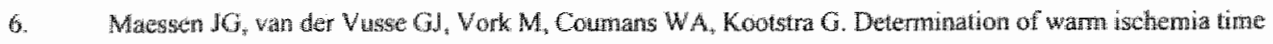
at donor nephrectony. Transplantation 1988; 45:14\%-1.52

7. Chan L, Fretch ME, Gadian DG, Morris PJ, Radda GK, Bore BD, Styles P. Study of human kidneys prior to transplantation by phosphonus nuclear magnetic resonance. In: Pegg DE, Jacobsen IA. Halasz NA. (cds). Presctwation; Basic and Applied Aspects. Lancester, UK, MTP Press, 1982:113-119

8. Bretan PN, Vigneron DB, James TL, Willams RD, Hricak H, Juenemann $K-P$, Y TSB, Tanagho EA. Assessment of renal wability by phosphorus-31 magnefic resonance spectroscopy. J Urol 1986; 135: 866869

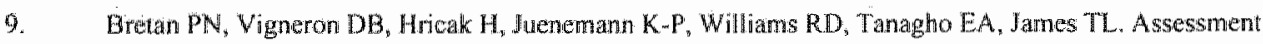
of renal preservation by phosphorus-3। magnetic resonance spectroscopy: in wivo normothermic blood perfision. J Urol 1986; 136:1356-1359

10. Pomer $\mathrm{S}$, Hull WE, Roehl L. Assessment of renal vidility for iransplantation by high field ${ }^{3}$ P-NMR. Transplant Proc 1988; 20:899-901

11. Bretan PN, Baldwin N, Nowick AC. Majors A, Easley K, Thian Ng, Stowe N, Rehm P, Streem SB, Steinmuller DR. Pretransplant assessment of renal viability by phosphorus-31 magnetic resonance spectroscopy. Transplantation 1989:48:48-53

12. Koln M, Ross H. Lactate dehydrogenase output of the excised kidney as an index of acute ischemic renal damage. Transplantation 1971; 11: $461-466$

13. Amemiya H, Suzuki S, Niiya S, Watanabe H, Ohara S, Kaneko $Y$, Yoshida K, Motomiya $Y$, Hirao $Y$, Okajima $\mathbb{E}$. Viability estimation of preserved dog kidneys based on the LDH activity in the preservation perfusate. Nippon Jinzo Gakkai Shi 1989; 31: 643-649 (abstract)

14. Liebau G, Klose HJ, Fischbach H, Pichlmaier. Simple tests for wiability of the hypothermic pulsatile perfused dog kidney. Surgery 1971; 70:459-466

15. Cohen GL, Ballardie FW, Mainwaring A, Johnson RWG. Lysosomal enzyme release during successfull 5-, 7- and 8-day canine kidney storage. In: Pegg DE, Jacobsen 1A, Halasz NA (eds). Preservation; Basic and Appliod Aspects. Lancester, UK, MTP Press, 1982: 249-251

16. Cho SI, Zatneraitis B, Ohmi N. Arias IM. Prediction of cadaver kidney function by ligandin analysis. J Surg Res 1981; $30: 361-364$

17. Reo PN, MeCauley I, Shapiro R, Bronsther O, Scautlebury V, Viwas C, Jordan M, Stara $T$. Inability of effuent hyaluronic acid levels to predict early graft function in clinical renal transplantation. Transplantation 1993:56:1540-1541

18. Smith RB, Terasaki PI, Martin DC. A rapid metabolic screening test to evaluate potential caclaveric kidney donors. JAMA 1967;201: 160-164

19. Yin $L$, Terasaki P $\mathrm{L}$. A rapid quantitated viability fest for transplant kidneys - ready for human trial. Clin Transplantation 1988;2:295-298

20. Sells RA, Bore PJ. McLaughlin GA, Johnson JN, Tymell 1. A predictive test of renal viability. Transplam Proc 1977.9: $1557 \mu 1560$ 
21. Naucter J, Bylund-Fellemis AC. Jonsson O, Kleist $\mathrm{H}_{4}$ Lundstan 5 , Petterson S, Schersten. Evalution of kidney viability during lypothermic perfusion or cold storage. Eur Surg Res 1984; 16:47.56

22. Fenzlein $\mathrm{PG}$, Abendroth $\mathrm{D}$, Schilling $\mathrm{M}$, Scthaid $\mathrm{M}_{\mathrm{s}}$ Land $\mathrm{W}$, Bochenical multisensot elenent for estimation of organ viability. Transplant Proc 1991:23: 1302-1303

23. Abendroth D, Schilling M, Fenzlein PG, Land W. Pretransplant assessnemt of renal viability by using ionselective electrodes - A pilot study. Transplant Proc 1993; 25:2563-2564

24. Satoh S, Stowe NT, Inman SR, Sankari BR, Magnusson MO. Novick AC. Renal waseular response to vasodilators following warm ischemia and cold storage preservation in dog kidneys. J Urol 1993, 149: $186-189$

25. Moncada S, Palmer RMJ, Higgs. EA. The discovery of nitric oxide as the endogenous nitrovasodilator. Hypertension 1988; 12:365-372

26. Lieberthal W, Renke $\mathrm{HG}_{\text {, Sandock }} \mathrm{KM}_{*}$ Valeri $\mathrm{CR}$, Levinsky $\mathrm{NG}$. Ischemia in the isolated erythrocyteperfused rat kidney: protective effect of hyy pothermia. Renal Physiol Biochem 1988; 11:60-69

27. Mason J, Welsch J, Torhorst J. The contribution of wascular obstruction to the functional defect that follows renal ischemia. Kidney Int $1987 ; 31: 65-71$

28. Heary ML, Sommer BG, Ferguson RM. Renal blood flow and intrarenal resistance predict immediate renal allograft function. Transplant Proc 1986; 18: $557-558$

29. Tesi RJ, Elkhammas EA, Davies EA, Henry ML, Ferguson RM. Pulsatile kidney perfusion for evaluation of thigh-risk kidney donors safely expands the donor pool. Clin Transplantation 1994; 8: 134-139

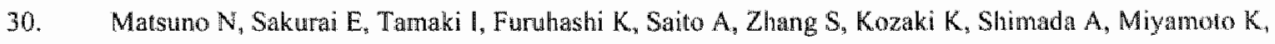
Kozaki M. Effectiveness of machine perfusion preserwation as a viability determination method for kidneys procured from non-heart-beating donors. Transplant Proc 1994; 26: 2421-2422

31. Baxby K, Johnson RWG. Prediction of kidney wiability before transpiantation. Br J Surg 1975; 62: 810812

32. Daemen JHC, Heineman E, Kootstra G. Viability assessment of non-heart-beating donor kidneys during machine preservation. Transplant Proc 1995; 27:2906-2908

33. Miller $\mathrm{CH}$, Alexander W $J_{\text {, Nahan }}$. Effect of warm ischemic damage on untrarenal distribution of how in preserved kidneys. Surgery 1972; 72: 193-202

34. Bonster MH, Yin M, Stubenitsky BM, Kemening GJ, wan Kroonenburgh MPG, Heidendal GAK, Halders SGEA, Heineman E, Buurman WA, Wijnen RMH, Tiebosch ATM, Bonke H, Kootstra G. Beneficial effect of machine perfusion on the preservation of remal microcirculatory integrity in ischemically damaged kidneys. Transplant Proc 1993; 25:3012-3016

35. Andrewrs PM. Petroll WM, Cavanagh HD, Jester JV Tandem scaning con focal microscopy (TSCM) of normal and ischemic living kidneys. Am I Anat 199!; 191:95-102

36. Andrews PM. Noninvasive vital microscopy to monitor tubular necrosis of cold-stored kidneys. Transplantation 1994; $57: 1143-1148$ 
GLUTATHIONE S-TRANSFERASE AS PREDICTOR OF FUNCTIONAL OUTCOME IN TRANSPLANTATION OF MACHINE PRESERVED NON-HEART-BEATING DONOR KIDNEYS JHC Daemen, APA Oomen, MA Janssen, L van de Schoot, BK van Kreel, E Heineman, G Kootstra

Transplantation 1997;63:89-93 


\section{Introductlon}

Due to the growing demand for organs for transplantation together with a stabilising supply of braindead, i. . heart-beating donors, there is a surge for altemative sources of grafts. One of these altematives is the use of organs from non-hearibeating (NHB) donors, which might reduce the shortage of kidneys for transplantation considerably. Organs are procured from $\mathrm{NHB}$ donors after final and irreversible cardiac arrest; therefore, organs sustain warm ischemic damage. The warm ischemic time (WIT), defined as the period between cardiac arrest and start of the cooling of the organs, is often of unknown duration. Because WIT is one of the most important factors determining transplant outcome, organs might eventually become nonviable with increasing WIT. Therefore, estimation of the ischemic damage is important; for the safe use of kidneys from NHB donors it is essential to define reliable parameters to assess the ischemic damage and possibly predict transpiant ourtcome.

Apart from the potential benefits on transplant results [1,2], preservation by machine perfusion (MP), i.e., perfusing the kidney continuously with cold solution, enables surgeons ta judge the condition of the graft by registering flow and pressure characteristics and analysing the washout of enzymes into the perfusate. An increase in intrarenal wascular resistance (IRR) during preservation is related to impaired posttransplant function [3]; release of the cytosolic enzyme lactate dehydrogenase ( $\mathrm{LDH}$ ) into the perfusion solution correlates with ischemia time and subsequent function [4]. The appearance of $\alpha$ glutathione S-transferase ( $\alpha$ GST) in the perfusate of continuously perfused kidneys was found to predict the development of posttransplant acute tubular necrosis (ATN)[5]. However, none of these parameters was ever used to measure warm ischemic damage in relation to graft viability and transplant outcome of NHB donor kidneys. The aim of this study was to assess warm ischemic damage in NHB donor kidneys, and to investigate the relationship between perfusion characteristics and release of enzymes and the functional outcome of the grafts.

\section{Materials and Methods}

All kidneys were from NHB donors and were preserved by MP at the University Hospital Maastricht. The organs were procured after final cardiac arrest in an unsuccessful cardiopulmonary resuscitation procedure (NHB donor caregory 2) or from NHB donors that sustained cardiac arrest after withdrawal of wentillatory suppont ( $M H B$ donor category 3). Several kidneys were procured from brain-dead donors experiencing irreversible cardiac arrest before organs could be recovered (NHB donor category 4)[6]. After consent was obtained, an in-situ preservation procedure using a double-balloon-triple-lumen femoral cooling catheter (AJ 6516, Porgès, Le Plessis-Robinson, France) was performed, as described 
in detail earlier [7]. Donor nephrectomy was perfomed in the operating room; subseguently, the kidneys wene prepared for MP on the back table and placed in specially designed organ chambers fitting into Gambro PF-3B perfusion machines (Gambro, Lund, Sweden). Before the kidneys were connected to the machine, a wedge biopsy from the cortex was taken for histology. As a perfusate for the MP, 500m of Belzer's perfusate, the University of Wisconsin solution for MP, was used [8]. Some NHB donor kidneys were shipped for MP to our center from other donor hospitais after a procurement procedure similar to ours; during transportation, these organs were stored on ice. One machine was used for one kidney. After the kidney was comnected to the perfusion system, perfusion flow was set to a systolic pressure of 60 $\mathrm{mmHg}$. The perfusion flow was kept constant, but the pressure was allowed to vary. Perfusion pressures (systolic, diastolic, and mean) were recorded at the beginning of the MP and atter 1,4, and 8 hr. IRR was calculated by dividing the mean pressure by the registered flow (in mmHg/mL/min per $100 \mathrm{~g}$ of kidney weight); a decrease reflected a reduced IRR. Samples for LDH and OCST analysis were taken from the perfusate at time points $0,1,4$, and 8 hr of preservation and immediately stored at $-70^{\circ} \mathrm{C}$ until ased. a.GST was quantitatively determined by using the NEPHKIT-ALPHA immunoassay designed for urine analysis (Biotrin International, Dublin, Ireland). Perfusate samples were assayed following the standard assay after being diluted 1:500. LDH was determined by standard colorimetric assay (Boehringer Mannheim, Almere, The Netherlands). Results were adjusted for kidney weight.

Kidneys were discarded and not used for transplantation whenever donor data, macroscopic appearance of the organs, perfusion characteristics and/or histological examination indicated excessive ischemic damage and raised doubt about viability [9]. Kidneys judged unsuitable for transplantation were preserved for at least $8 \mathrm{hr}$, and data were collected as described before (not-transplanted [NOT-TX] group). Kidneys considered suitable for transplantation were allocated to recipients by the Eurotransplant organisation and remained in the perfusion machine until grafting.

Data about posttransplant function were collected by questionnaire and the transplanted grafts were divided into two groups. The functioning $(F)$ group included kidneys that gave life-sustaining renal function, whether temporarily requiring postransplant dialysis or not. The non functioning (NF) group included those grafts that failed to give renal function, no matter what the cause, and dialysis had to be continued. The $\mathrm{F}$ group was further subdivided into delayed function (DF) and immecliate function (IF) subgroups according to whether posttransplant dialysis was needed.

Results are given as mean $\#$ SD; statistical significance for differences were calculated by nonparametric Mann-Whitney U-test and chi-square test for differences between groups, where appropriate. 
P values less than 0.05 were considered significant.

\section{Results}

Between July 1993 and November 1995,67 kidneys procured from NHB donors were preserwed by MP and yielded data for analysis (table 1). Twenty-one kidneys were not transplanted (NOT-TX group), 37 grafts entered the $\mathrm{F}$ group $\mathrm{p}_{5}$ and 9 entered the NF group. Basic donor data were equal for the $\mathrm{F}$ and NF groups (serum creatinine: $122 \pm 72$ and $130 \pm 62$ umoli $L, p=0.28 ;$ donor age: $41.6 \pm 15.7$ and $48.7 \pm 16.5$ years, $\mathrm{p}=0.37$, respectiwely). In the NOT-TX group, serum creatinine was $139 \pm 57 \mu \mathrm{mol} / \mathrm{L}(\mathrm{p}=0.03$ and $p=0.30$ for $F$ and $N F$ groups, respectively), and donor age was $46.2 \pm 15.0$ years $(p=0.55$ and $p=0.39$ for

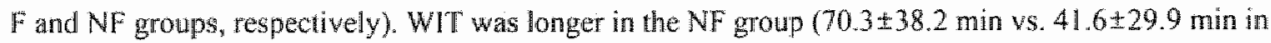
the F group, $p=0.04)$, whereas cold ischemic time was not different $(31.1 \pm 10.2$ and $33.0 \pm 5.1$ hr in the F and $N F^{2}$ groups, respectively; $\left.\mathrm{p}=0.13\right)$. In the NOT-TX group, WIT $(84.0 \pm 57.1$ min) was longer than in the F group ( $p=0.001$ ) but equal to WIT in the NF group $(p=0.77$ ).

Table 1. Donor data for F, NF, and NOT-TX groups ${ }^{\text {a }}$

\begin{tabular}{|c|c|c|c|}
\hline & $\mathrm{F}^{m}$ & $\mathrm{NF}$ & NOT-TX \\
\hline $\mathrm{n}$ & 37 & 9 & 21 \\
\hline donor age (years) & $41.6 \pm 15.7$ & $48.7 \pm 16.5$ & $46.2 \pm 15.0$ \\
\hline oreatinine $(\mu \mathrm{mol} / \mathrm{L})$ & $122 \pm 72$ & $130 \pm 62$ & $139 \pm 57^{b}$ \\
\hline WhT (min) & $41,6 \pm 29,9$ & $70.3 \pm 38.2^{b}$ & $84.0 \pm 57.1^{b}$ \\
\hline cold ischemic time (hr) & $31.1 \pm 10.2$ & $33.0 \pm 5.1$ & $\ldots$ \\
\hline
\end{tabular}

Imrarenal Vascular Resistance. Except at 1 hr, there was no significant correlation between WIT, as determinant of ischemic damage, and IRR ( $p$ values $>0.05)$; linear correlation was found at 1 hr ( $1=0.272$; $p=0.04$ ). The IRR of NF grafts increased significantly when compared with Fo grafts at 4 and 8 hr of preservation time $(p=0.02$ and $p=0.04$, respectively; fig. 1A). The NOT-TX group was significantly 
different from the F group and equal to the NF group for all time points.

Lactate Dehydrogenase. No correlation was found between WIT and LDH activity in the perfusate. When comparing the F and NF groups, no differences were found fig. IB). The activity in the NOT-TX group was equal to that in the NF group, but increased when compared wh the F group. There was no activity at $0 \mathrm{hr}$.

$\alpha$-Ghuthione S-Transferase. $\alpha$ GST release at 4 hr and 8 hr correlated well with the WIT (fig. 2) (linear correlation: $r=0.353, p=0.009$, and $r=0.346, p=0.011$, respectively $)$. No comelations were found behween $\alpha G S T$ and IRR for all time points ( $p>0.05$ ). Release of $\alpha$ GST correlated well with the release of LDH into the perfusate, but just at $4 \mathrm{hr}$ and $8 \mathrm{hr}(r=0.0267, p=0.04$, and $r=0.364, p=0.007$, respectively). Compared with the F group, $\alpha$ GST levels were significantly elevated in the NF group at all time points (p-values $0.02,0.005$, and 0.004 at $1 \mathrm{hr}, 4 \mathrm{hr}$, and $8 \mathrm{hr}$, respectively; fig. $1 \mathrm{C}$ ). Organs in the NOT-TX group had equally high $\alpha$ GST values in comparison to the NF group; values were higher in comparison to the F group, except at 1 hr $(p=0.19)$.

No enzyme was detectable at the start of MP. The poorer the posttransplant graft function, the higher the level of aGST found; when the posttransplant function was examined per quarile of aGST level at 4 $\mathrm{hr}$, the proportion of never-functioning grafts increased significantly (table $2 ; \mathrm{p}=0.009$ ).

Tablle 2. Posttransplant function per $\alpha$ GST level after 4 hr of MP

\begin{tabular}{|c|c|c|c|}
\hline Quartiles & aGST al $4 \mathrm{hr}^{\mathrm{a}}$ & $n$ & $F: N F(\%)$ \\
\hline 1 & $702 \pm 184$ & 12 & $12: 0(100)$ \\
\hline 2 & $1280 \pm 256$ & 12 & $10: 2(83)$ \\
\hline 3 & $2108+288$ & 11 & $9: 2(82)$ \\
\hline 4 & $3870 \pm 920$ & 11 & $6: 5(55)$ \\
\hline
\end{tabular}

\footnotetext{
Values are expressed as mean $\mathrm{SD}$ in $\mu \mathrm{g} / 100 \mathrm{~g}$ kidney weight.

${ }^{b}$ The values represent the number (\%) of kidneys in the F group; posttransplant function worsened with increasing oGST level $(p=0.009)$.
} 
Figure L. IRR (A), LDH (B), and GST (C) during MP.

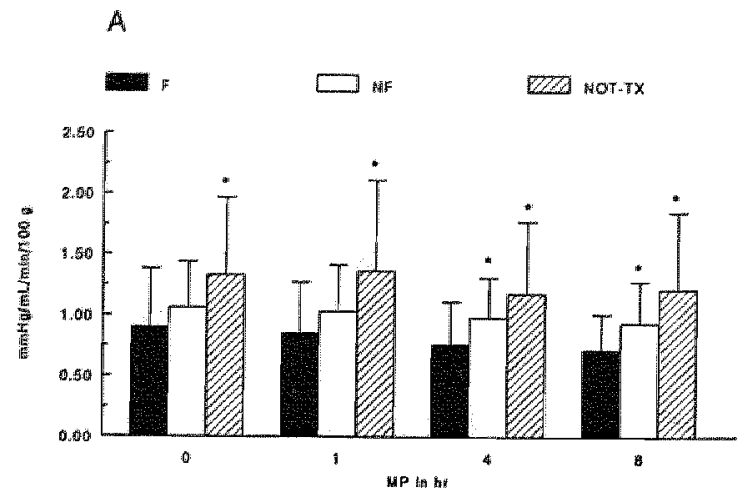

B

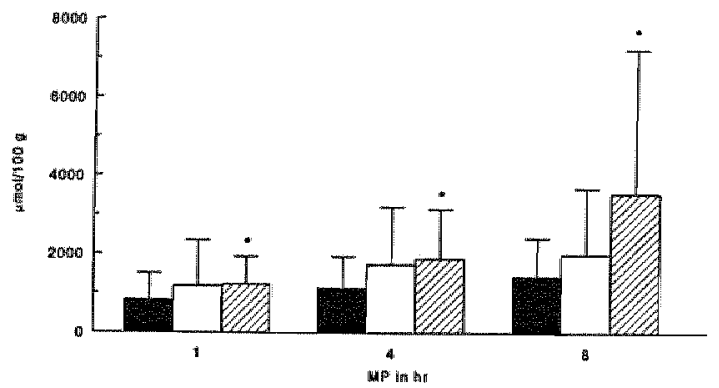

C

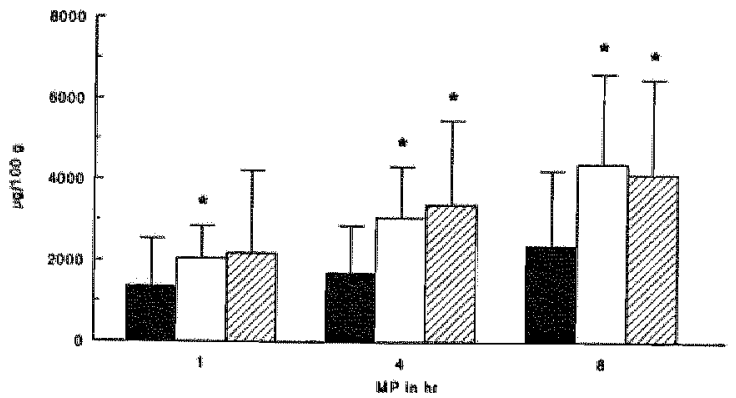

* Significantly different from the F group. 
Within the $F$ group, the DF $(n=26)$ and $I F$ ( $n=11$ ) subgroups were not differen for donor data and ischemia times. Results for the analysed parameters are depicted in table 3. Remarkably, neither $1 R R$ nor OGST differed for $I F$ and DF, whereas LDH could discriminate very well between them ( $\mathrm{p}$-values $0.0003,0.0003$ and 0.0001 at $1 \mathrm{hr}, 4 \mathrm{hr}$, and $8 \mathrm{hr}$, respectively).

\section{Discussion}

In the early days of transplantation, efforts were made to predict transplant outcone during preservation. Probably due to the almost exclusive use of brain-dead donors and the increasing effectiveness and safery of the preservation methods for renal grafts, interest in this subject has decreased. The increasing demand for organs, however, has renewed interest in the use of organs from NHB donors. Because all these organs are damaged by warm ischemia parameters that may quantify this damage are currently regaining importance. Several viability parameters based on the determination of nucleotides, enzyme and electrolyte release, and functional and morphological status of the kidneys have been proposed. However, currently none of these parameters that may estimate warm ischemic damage and predict transplant outcome is routinely used in clinical practice [10-14]. Several parameters potentially useful for MHB donor kidneys were evaluated in this study.

The IRR reflects the vasoconstrictive response of the renal vascular bed to the ischemic insult. The precise mechanism of this increasing resistance is still unclear but might be the result of the local release of vasoconstrictive agents and the reduced ability of the damaged vascular endothelium to release endothelium derived relaxing factor (identified as nitric oxide) [15-17]. The congestion of arythrocytes in capillaries additionally increases the IRR and is an important factor in postischemic renal dysfunction [18]. As a result, the caiculated IRR can be seen as a parameter revealing warm ischemic damage [19]. In some clinical programs, IRR and perfusion flow are used to salely expand the donor pool with kidneys from marginal donors; kidneys with high IRR are discarded, although different cut-off points are reported [20,21]. However, the IRR is dependent on perfusion flow, and thus organs must be connected to the perfusion system perfectly. Unobserved vascular leakage during perfusion and mulciple arteries may make tlow and pressure registrations less reliable. Therefore, despite the observed differences between the $F$ and NF groups, we are reluctant to use IRR as a sole parameter to judge kidney viability. However, IRR may be waluable in confirming expected functionall outcome predicted by other paramelers. 
Figure 2. Correlation between WT and oCST after 4 hr of MP

O NE

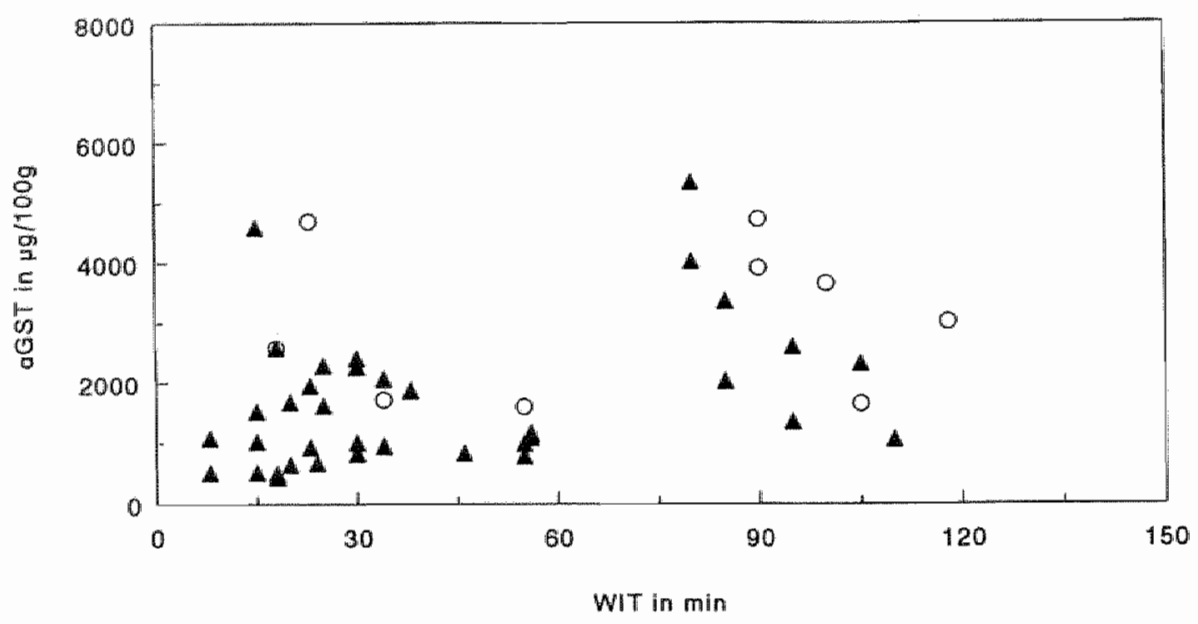

Linear correlation: $r=0.353 ; p=0.009$.

Table 3. Values for IRR, LDH, and $\alpha$ GST during MP for IF and DF subgroups ".

\begin{tabular}{|c|c|c|c|c|c|c|}
\hline & \multicolumn{2}{|c|}{$\begin{array}{l}\text { IRR } \\
\text { (mmig/mL/min per } \\
100 \mathrm{~g} \text { kidney weight) }\end{array}$} & \multicolumn{2}{|c|}{$\begin{array}{l}\text { LDH } \\
(\mu \text { mol per } \\
100 \mathrm{~g} \text { kidney weight })\end{array}$} & \multicolumn{2}{|c|}{$\begin{array}{l}\alpha G S T \\
(\mu g \text { per } \\
100 \mathrm{~g} \text { kidney weight) }\end{array}$} \\
\hline$T^{*}$ & IF & $\mathrm{DE}$ & $\mathbb{I F}^{*}$ & DF & IF & $\mathrm{DF}$ \\
\hline 0 & $0.88 \pm 0.31$ & $0.90+0.54$ & - & .. & $\ldots$ & $\ldots$ \\
\hline 1 & $0.82 \pm 0.35$ & $0.87 \pm 0.45$ & $412 \pm 184$ & $1002 \pm 750^{b}$ & $940 \pm 612$ & $\| 542 \pm 1308$ \\
\hline 4 & $0.75 \pm 0.36$ & $0.76 \pm 0.35$ & $602 \pm 264$ & $1354 \pm 854^{b}$ & $1320 \pm 720$ & $1834 \pm 1284$ \\
\hline 8 & $0.68 \pm 0.24$ & 0.7440 .32 & $748 \pm 286$ & $1758 \pm 1040^{b}$ & $1598 \pm 704$ & $2730+2120$ \\
\hline
\end{tabular}

"Values are expressed as mean $\pm \mathrm{SD}$.

bignificantly different from the IF subgroup ( $\mathrm{p}<0.001$ ). 
Relatiwely independent from the perfusion how is the absolute enzyme release into the perfusate. It was already obserwed by Belzer in the 1960s that, with ischemically danaged kidneys, the peak release of LDH appeared later in the course of MP when compared to undamaged kidneys, probably due to the initially impaired perfusion flow [22]. Washout of ubiquitous enzymes during single organ perfusion reflects the number of cells damaged in the organ. In the ischemic state, plasma membrane integrity is altered, and its permeability is lost through different pathophysiological pathways $[23,24]$. Although the subsequent release of enzymes from cells suggests severe membrane damage, in not necessarily indicates the death of these cells [25]. In this context, the cellular enzyme LDH is often reported and found to correlate with the duration of renal ischemia and postischemic function $[4,22,26]$. In nonischemic kidneys, it has been shown to be an adequate indicator of preservation injury [27]. Although during single-organ perfusion all LDH in the perfusate originates from the kidney, it remains unclear which renal cells are damaged specifically, since LDH is present in almost all living cells. Also, LDH is released into the perfusate by damaged erythrocytes that after the initial cold flush are trapped in the renal microwasculature and being washed out during MP. This lack of specificity may explain why in our study LDH could not distinguish between damaged grafs with and without function (F versus NF).

Glutathione S-transferase is a cytosolic enzyme present in liver, kidneys, small intestine, testes, ovaries and adrenal glands [28]. More important, within the kidney the $\alpha$-isoenzyme, oGST, is confined exclusively to the proximal tubule (PT) celis [29]. Glutathione S-Iransferase conjugates a great variety of molecules that are considered to be detoxifying. The conjugate is further degraded by enzymas of the gamma-glutamyl cycle to become mercapturic acid, which is excreted in the wrine [30]. Gilutathione S* tranterase, formerly known as ligandin, assessed during preservation of kidneys without ischemic damage, has been reported to predict ATN and transplant outcome well [5,31]. The determimation of glutathone S-transferase iscenzymes in the urine appeaned to be very useful in differentiating various renal tubular tesions $[32,33]$. Warm ischemia predominantly damages the PT cells $[15]$; therefore, the appearance of aGST in the perfusate may reflect the number of PT cells damaged. Renal grafts not functioning after transplantation because of too severe ischemic damage are considered to have irreversible tubular necrosis. The level of $\alpha$ GST as a specific and quantitative marker for PT damage is anticipared to correlate well with WIT and thus to predict functional outcome adequally, which is exactly what we found. The fact that oGST is not able to diferentate between IF and DF grafts (table 3) may be due to the exclusive use of NHB donor kidneys in this study. These grafts all sustan warm ischemic damage; even in the IF and DF subgroups, WIT was $44.7 \pm 10.9$ and $40.3 \pm 27.6 \mathrm{~min}$, respectively. This is enough to cause PT cell damage and the release of $\alpha G S T$, which does not always result in clinically evident ATN. On the other hand, that LDH is able to identify IF grafts within the F 
group indicates that in genteral only the minimally damaged grafts can give immediate function.

The strong comelation between WT and release of CGST and the ability of this enzyme to differentiate between functionng and non-functioning NHB donor kidneys are important because $\alpha$ GST can be used to define marging for the safe use of NHB donor kidneys. Classifying the graft function according to the OCST lewel (table 2) showed that high aCST release was associated with significantly poorer graft function. Using at random for $\alpha$ GST at $4 \mathrm{hr}$ an upper level of $3000 \mu \mathrm{g} / 00 \mathrm{~g}$ of kidney as the limit for the vilability of organs, would have resulted in the transplantation of 37 kidneys of which 4 woild not bave functioned. The predictive value of this cut-off point for transplanting a viable kidney was $89 \%$; the predictive value for discarding a nonviable kidney was $56 \%$. Exclusion of transplanted kidneys from the NF group that failed due to other factors than ischemia, such as acute rejection or renal wein thrombosis, would improve the predictive value of a positive test. Indeed, itn our study three of the four kidneys that showed no function, and had an $\alpha G S T$ level at 4 hr of less than the proposed $3000 \mu g$, failed for reasons other than excessive ischemic damage, proven by functioning contralateral kidneys from the same donor. Since levels for enzyme release in the NOT-TX group are close to data of the NF group, it may be assumed that these discarded kidneys would not have functioned when transplanted. "ransplanting these probably nonviable grafts would have improved the predictive value of a negative test remarkably.

This study shows that MP offers possibilities for evaluating renal grafts from NHB donors. As could be expected, NF kidneys suffered from longer WIT than F kidneys. OGST, and to a lesser extent, IRR were able to distinguish viable ( $F$ group) from nonviable grafts (NF group) early in the course of preservation. Only aGST showed a strong correlation with WTT and is an adequate predictor of functional outcome. The LDH release into the perfusate could identify relative undamaged grafts but is not useful in predicting nonfunction. It should be realised, however, that transplant outcome is mult factorial and that warm ischemic damage, although wery important, is just one factor. We have confirmed that MP is the preserwation method of choice for NHB donor kidneys, and we are conwinced that the parameters discussed, especially the measurement of aOST, will help to select nonviable kidneys from the valuable kidneys for transplantation.

\section{References}

1. Booster MH, Wijnen RMH, Yin M, Tiebosch ATM, Heineman E, Maessen JG, Buurman WA, Kurvers HAIM, Stubenitsky BM, Bonke H, Kootstra G. Enhanced resistance to the effects of normothermic 
ischemia in kidneys using palsatile machine perinusion. Transplant Proc 1993,25: $3006-3011$

2. Matsuno N, Sakuma I, Tamaki I, Uchiyama M, Kozaki K. Kodaki M. The effect of machine perfusion preservation versus cold storage on the function of kidneys from non-heat-beating donors. Transplantation $1994 ; 57 ; 293-294$

3. Henry ML, Sommer BG, Ferguson RM. Renal blood flow and intrarenal resistance predict immedtate renal allograft function. Transplant Proc 1986; $18: 557-558$

4. Kohn $M$, Rass $H$. Lactate dehydrogenase output of the exeised kidney as an index of acute ischaemic renal damage. Transplantation 1971:11:461-464

5. Cho SI, Zalneraitis B, Ohmi N. Arias IM. Prediction of cadaver kidney function by ligandin anallysis. J Surg Res 1981:30:361-364

6. Kootstra G, Daemen ${ }_{1} \mathrm{HC}_{\mathrm{b}}$ Oomen APA Categories of non-heart-beating donors. Transplant Proc 1995; $27: 2893-2894$

7. Heineman $E_{n}$ Daemen JHC, Kootstra $G$. Non-heart-beating donors: methods and techniques. Transplam Proc 1995;27: 2895-2896

8. McAnulty JF, Ploeg RI, Southard JH, Belzer FO. Successful five-day perfusion preservation of the canine kidney. Transplantation 1989:47:37-41

9. Daemen JHC, Heineman $\mathrm{E}$, Kootstra $\mathrm{G}$. Viability assessment of non-fheart-beating donor kidneys during machine preservation. Transpl Proc 1995; 27: 2906-2908

10. Buhl MR, Kemp $\mathrm{G}$, Kemp $\mathrm{E}$. Hypoxanthine excretion during preservation of rabbit kidneys for transplantation. Transplantation $1976 ; 21: 460 \times 467$

11. Maessen JG, van der Vusse GI, Vork M, Coumans WA, Kootstra G. Determination of warm ischentia time at donor nephrectorny. Transplantation 1988; 45: 147-152

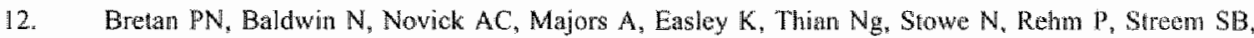
Steinmuller DR. Pretransplant assessment of renal viability by phosphorus-31 magnetic resonance spectroscopy. Transplantation 1989; 48:48-53

13. Yin L., Terasaki Pl. A rapid quantitated wiability test for transplant kidneys-ready for human trial. Clin Tiransplantation $1988 ; 2: 295-298$

14. Andrews PM. Noninvasive wital microscopy to monitor tubular neerosis of eold stored kidneys. Transplantation 1994; $57: 1143-1148$

15. Lieberthal W, Renke HG, Sandock KM, Valeri CR, Levinsky NG. Ischemia in the isolated erythrocyleperfused rat kidney: protective effect of hypothermia. Renal Physiol Biochem 1988; : : : 60-69

16. Satoh S, Stowe NT, Inman SR, Sankari BR, Magnusson MO, Novick AC, Remal vasculat response to vasodilators following warm ischemia and cold storage preserwation in dog kidneys. I Urol 1993; 149 : $186 m .189$

17. Moncada S, Palmer RMJ. Higgs EA. The discovery of nitric oxide ats the endogenous natrovaswaliator. Hypertension 198:8; 12:3654372

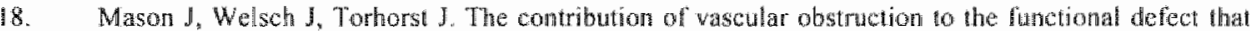
follows renal ischemia. Kidney Int 1987;31:65-71 
19. Johnson RWG, Anderson M, Marley AR, Taylor RMR, Swinney J. Twenty-four hour preservation of kidneys injuted by prolonged wam ischemia. Transplantation 1972; 13:174-179

20. Tesi R, Elkhammas EA, Davies EA, Herry ML, Fergenson RM. Pulsatile kidney perfusion for evaluation of high-risk kidney donors safely expands the donor pool. Clin Transplantation 1994; 8: 134-139

21. Matsuno $\mathrm{N}_{\text {, Sakurai }} \mathrm{E}_{\mathrm{s}}$ Tamaki I, Furuhashi $\mathrm{K}$, Saito $\mathrm{A}$, Zhang $\mathrm{S}$, Kozaki K, Shimada A, Miyamoto K. Kozaki M. Effectiveness of machine perfusion preservation as a vability determination method for kidneys procured from non-hear-beating donors. Transplant Proc 1994; 26:2421-2422

22. Belzer $\mathrm{FO}$, Ashby BS, Downes GL Lactic acid dehydrogenase as an index of future function of cadaver kidneys during isolated perfusion. Surg Forum 1968; 19:205-206

23. Weinberg $\mathrm{M}$. The cell biology of ischemic renal injury. Kidney Int 1991; 39:476-500

24. Siegel NJ, Devarajan P, vary Wh S. Renal cell injury: metabolic and structural alterations. Pediatric Res 1994; 36: 129-136

25. Leaf $A$, Macknight $A D C$, Cheung JY, Bonventre IV. The cellular basis of ischemic acute renal failure. In: Andreoli TE, Hoffman JF, Fanestil DD, Schuitz SG, eds. Physiology of membrane disorders. New York: Plenum Publishing Comporation, 1986: 769

26. Codd JE, Garvin PJ, Morgan R, Jellinek M, Newton WT. Allograft viability determined by enzyme analysis. Transplantation $1979 ; 28 ; 447-450$

27. Lieban $\mathrm{G}, \mathrm{Klose} H \mathrm{H}$, Fischbach $\mathrm{H}$, Pichlmaier H. Simple tests for wiability of the hypothermic pulsatile perfused dog kidney. Surgery 1971; 70:459-466

28. Shermarn M, Titmuss S, Kirsch RE. Glutathione S-transferase in human organs. Biochem Int 1983;6: $109-118$

29. Haurrison DJ, Kharbanda R, Sicott Cunningham D, McLellan LI, Hayes JD. Distribution of glutathione Stransferase isoenzymes in thuman kidney: basis for possible markers of renal injury. J Clin Pathol 1989; 42: $624-628$

30. Mehler AH. Amino acid metabolism II: metabolism of the individual amino acids In: Devlin TM, ed. Textbook of biochemistry; with clinical correlations. New York: Wiley-Liss, 1992: $491-528$

31. Feinfeld DA, Levine RD, Levine SD, Fleischner G. Ligandin in perfusate from transplanted kidneys: a test tor tubular necrosis. Nephron 1978; 21:38.4

32. Bäckman L, Appelkvist E- L , Ringden $O$, Dallner $G$. Glutathone transferase in the urine: a marker for post-1rarnsplant tubular lesions. Kidney Int 1988, 33:571-577

33. Sundberg AOM, Appelkwist E-L, Bäckman L, Dallner G. Urinary $\pi$-class glutathione rransferase ats an indicator of tubular damage in the human kidney. Mephron 1994; 67: 308-316 
SUMMARY AND CONCLUSIONS /

SAMENVATTING EN CONCLUSIES 


\section{Summary and Conclusions}

Transplantation is the preferred treament of end stage renal failure. A successful renal transplantation improves the quality of life and at a lower cost than dialysis. However, ever since the first transplant there has been an increasing shortage of donor organs. In $1996,11,000$ patients awaiting a kidney transplant were registered at the Eurotransplant Foundation. That year about 3,300 renal transplanis were performed, from which 250 from living donors. Although momentarily the potential of brain dead, heartbeating (HB), donors is not employed to its full extent, sufficient numbers of donor organs will probably never be realised by HB donation alone. Due to the shortage of donor kidneys, more attention should be paid to non-heart-beating (NHB) donation, i.e. donation by donors that died of cardiac arrest, as a possible source of donor organs. A.lthough NHB donation exists since the beginning of transplantation, nowadays it is just employed at a minor scale.

NHB kidney donors sustain irreversible cardiac arrest and due to the circulatory collapse the organs are damaged by ischemia. In CHAPTER ONE the concept of NHB kidney donation is outlined. According to the donation and preservation protocols at the University Hospital Mastricht, several of the proposed cooling and preservation techniques are described and results are compared. It is obvious that not all NHB donors are comparable and in CHAPTER TWO four categories of NHB donors are proposed (category 1 Dead on ariwal, category 2 Unsuccessful resusciation, calegory 3 A waiting cardiac arrest, and category 4 Cardiac arrest while brain dead).

In CHAPTER THREE the results of an important study are described. Depending on medical surtability of the NHB donor and the possibility to execute a donation procedure, annually 2 to 4.5 times more kidneys may come available from NHB donors than from $\mathrm{HB}$ donors. The largest proportion (68\%) of these potential NHB donors is located at emergency room, intensive care and coronary care units. The potential donors at these departments are also the medically most suitable. Focusing on these hospital units for implementing routine procurement of kidneys from NHB donors is probably most effective.

Due to the circulatory arrest NHB donor organs are ischemically damaged and transplant results may be effected negatiwely. Earlier studies showed that NHB donor kidneys suffered more delayed function (DF) upon transplantation but that long term results were comparable to those with HB donor kidneys. From experimental work it was understood that machine perfusion (MP) preservation was superior to preservation by simple cold storage (CS). Based on these data a clinical study in which NHB donor 
kidneys preserved by MP are compared to NHB donor kidneys preserved by CS, has been conducted as described in CHAPTER FOUR. Upon transplantation MP preserved ongans functioned better than CS preserved organs, especially after prolonged warm ischemia (over 45 minutes). Just preserving NHB donor kidneys by MP is not enough to achieve a short-term transplant outcome sunilar to that of HB donor kidneys preserved by CS, as is described in CHAPTER FIVE. The DF rate is higher with NHB donor kidneys (49\% vs $19 \%$ ) and apparently more than MP alone is necessary to eliminate the negative effects of warm ischemia.

The ischemic insult that a NHB donor kidney suffers may be so extensive that the organ is not viable any more. Upon transplantation such a kidney will not recover but will show primary non-function (PNF). This PNJ has to be prevented in order to safely expand the potential NHB donor pool. Parameters that determine ischemic damage and thus may predict transplant outcome are very important. In CHAPTER SIX a review is given of viability parameters as proposed in the literature.

MP enables viability assessment and in CHAPTER SEVEN several parameters potentially useful as viability predictors are studied during the preservation of NHB donor kidneys. The level of $\alpha$ glutathione $S$-transferase $(\alpha G S T)$ in the perfusate appears to be a good parameter to differentiate viable from nonviable kidneys. $\alpha$ GST is an enzyme that in the kidney is confined to the proximal tubular cells and thus reflects proximal tubular damage. There is a strong correlation with the period of warm ischemia sustained and the functional transplant outcome can be predicted adequarely. By defining a maximum level for $\alpha$ GST $(3,000 \mu \mathrm{g} / 100 \mathrm{~g}$ kidney tissue after 4 hours preservation) and excluding kidneys with higher values from transplantation, transplanting NHB donor kidneys with a high risk of PNF can be prevented.

In this thesis it has been shown that the pool of potential NHB donors is at least twice as large is the nool of potential HB donors. Introduction of NHB donation on a large scale will elliminate the shortage of donor kidneys. In the future it might be possible to accept other organs than kidneys from NHB donors for transplantation (livers and lungs). Incidentally this is done in 'ideal' NHB donor's from category 3. Performing this on a widespread basis might reduce or even eliminate the shortage of these organs as well.

Important at iniroduction of protocols is, that bealth care workers are familiar with NHB donation, as they have to recognise potential NHB donors and start the donation procedure. The procedure in NHB donation is relatively simple and introducing of a cooling catheter into a femoral artery, as described in 
our protocol, can be done almost everywhere.

For the relatives donation by a NHB donor is as acceptable as donation by a HB donor. In our experience refusal rates are cqual in NHB and HB donation. We have also experienced that potential NHB donors ard not recognised as such. Therefore education of public as well as health care workers is essenthal.

In The Netherlands legislation recently has changed and now it allows to perform preliminary action for keeping organs suitable for transplantation. Thus, even before consent can be obtained, with this legislation introduction of a catheter and starting organ cooling is allowed for in NHB donation. Potential NHB donors will be more accessible and the donation procedure will improve. Additionally, as part of the new law a nation-wide registration system will be implemented that will give people the opportunity to be registered as organ donors. Today a large proportion of potential donations may not be realised because the deceased"s wish is not known and the relatives cannot consent to donation in time Hopefully this national registration will provide a solution to this problem and enable successful implementation of NHBi donation protocols. Probably only an 'opting-oul' legislation that makes everybody an organ donor unless registered otherwise, will allow for maximum profit by the NHB donor potential.

From our studies MP appears to be the superior preservation method. MP preservation gives better functional results of transplanted NHB donor kidneys than CS preservation. Furthermore through viability testing MP can prevent the transplantation of non-viable kidneys. Through assessing $\alpha G S T$ values during MP, the ischemic damage of the kidney and thus its viability can be established. In this way the fear of transplanting a non-viable kidney can be diminished. This will improve the acceptation of NHB donation and lead to an increasing number of donation procedures. Despite MP NHB donor at though this is not the case in our $\mathrm{NHB}$ donor kidneys. In spite of the fact that DF seems not to cause rejection and graft loss in NHB donor kidneys, it is considered a negative aspect of transplanting NHB donor kidneys.

By developing preservation solutions especlally for ischemically damaged kidneys the ischemic organ damage and thus DF may become treatable. From experimental studies in animals it seems possible to alleviate reperfusion damage and reduce DF rates by treating the recipient (platelet-activating-factor antagonist, adenosine inhibition). Of course additional damage to the already ischemically damaged kidneys must be prevented and the organ should be transplanted under the best conditions possible. Therefore, recipients should be selected carefully, preservation time should be kept to a minimum, and 
cyclosporin nephrotoxicity may be prevented by induction immunotherapy.

MP is an important aspect in NHB kidney donation and it is desirable to designatte preservation centers. Here NHB donor kidneys, and especially those with extended wam ischemic damage, can be preserved by MP and their viability can be assessed. In such preservation centers continuous reseanch will be done focusing on preservation methods for ischemically damaged kidneys and other ways to alleviate DF. 


\section{Samenwatting en Conclusies}

De vookkursbehandeling van terminale nierinsufficientie is transplantatie. Een succesvolle nientransplantatie verbetert de kwaliteit van leven van de patient en is kostenbesparend ten opzichte van dialyse. Echter sinds de eersite niertransplantaties is er steeds een tekort aan donororganen geweest dat steeds verder toeneemt. In 1996 waren bij Eurotransplant ongeveer 11.000 patiënten geregistreerd in afwachting van een niertransplantatie. In dat jaar werden minder dan 3300 miertransplantaties verricht, waarvan 250 met nieren van lewende donionen. Hoewel momenteel het potentieel aan hersendode, heartbeating (HB), donoren zeker niet volledig voor donatie word benut, is het onwarschijnlijk dat van $\mathrm{HB}$ donoren alléén ooit woldoende transplanteerbare nieren zullen worden verkregen. In het kader van dit orgaantekort krijgt de non-heart-beating (NHB) nierdonatie, dus donatie door donoren die overleden zinn aan een hartstilstand, steeds meer aandacht als alternatieve bron van donororganen. Alhoewel NHB donatie reeds sinds het begin van de orgaantransplantatie bestaat, wordt het momenteel slechts op kleine schaal toegepast.

Hartode nierdonoren overlijien ten gevolge wan een hartstilstand waardoor er sprake is van een circulatiestilstand en er ischaemische orgaanschade onistaat. In HOOFDSTUK EEN wordt het principe van NHB nierdonatie beschreven. Aan de hand van het donatie en preservatie protocol van het Academisch Ziekenhuis Maastricht wonden de verschillende koel- en preservatie technieken beschreven en worden resultaten vergeleken. Duidelijk wordt dat $\mathrm{NHB}$ donoren niet zonder meer onderling vergelijkbaar zijn. In HOOFDSTUK TWEE worden vier NHB donorcategorieën onderscheiden en beschreven (categorie 1 Dead on arrival, categorie 2 Unsuccessful resuscilation, categorie 3 Awaiting cardiac arrest en categorie 4 (ardiac arest while brain dead).

Een belangrijke studie is gedaan in HOOFDSTUK DRIE. A thankelijk van de medische geschiktheid van de NHB donor en de praktische witvoerbaarheid van een donatie procedure, blijken er jaarlijks 2 tot 4,5 mat zoveet nieren voor transplantatie beschikbaar te kunnen komen van NHB donoren dan thans van HB donoren. Het overgrote deel van de potentiële NHB nierdonoren $(68 \%)$ kan gevonden worden op de Eerste Hulp afdeling, lntensive Care Unit en Coronary Care Unit. De potentiele donoren op deze afdelingen zijn tevens medisch het meest geschikt. Om het potentieel aan NHB nierdonoren zo efficiënt mogelijk te benutten, zullen NHB donatie protocollen dan ook met mame op deze afdelingen ingevoerd moeten worden. 
Door de circulatiestilstand worden bij NHB donoren de organen per defnitie ischaemisch beschadigd. Dit kan de transplantatieresultaten negatief beinvloeden. Eerdere studies hebben laten zien dat bij transplantatie van NHB donomieren weliswar meer delayed function' (DF) optreedt, echter dat de lange termijn resultaten vergelijkbaar zijn met die van $\mathrm{HB}$ donomieren. Uil dierexperimenteel onderzoek is gebleken dat preservatie van ischaemisch beschadigde nieren middels machine perfusie (MP) cen beter functioneel resultaat geef dan preservatie middels 'cold storage' (CS). Op basis van deze gegevens is in HOOFDSTUK VIER een klinische studie beschreven wantbj NHB donomieren gepreserweerd middels MP zijn wergeleken met NHB donomieren gepreserveerd in CS. Bij transplantatie wordi bij MP een gunstig effect op het functionele resultaat waargenomen dat met name optreed bij lange warne ischaemie duur (langer dan 45 minuten). Uit het in HOOFDSTUK VIJF beschreven ondergoek blijkt het niet mogelijk te zijn met NHB donomieren de korte temijn resultaten van HB donomieren gepreserveerd middels CS, te evenaren door alleen MP toe te passen. Er wordt nog steeds cen hoger DF percentage gevonden bij NHB donomieren (49\% vs 19\%) en kennelijk is er méer nodig dan alléén MP" om de negatieve effecten van ischaemie te elimineren.

De ischaemische schade aan een NHB donomier kan dusdanig zijn dat deze niet meer vitaal is. Een dergelijke nier zal na transplantatie niet herstellen en 'primary non-function' (PNF) geven. Voor het verder uitbreiden en weilig toepassen van NHB nierdonatie moet PNF zoweel mogelijk voorkómen worden. Parameters die ischaemische schade meten en zo het transplantatieresultaat kunnen voorspellen. zijn van groot belang. In HOOFDSTUK ZES wordt een owerzicht gegeven van in de literatur geopperde parameters. MP biedt de mogelijkheid metingen te verrichten en in HOOFDSTUK ZEVEN worden tijdens preservatie van NHB donornieren verscheidene parameters bestudeerd. Het in het perfusaat bepalen van het $\alpha$ glutathion S-transferase (oGST), een enzym dat in de nier slechts woorkomt in de proximale tubulus, blijkt een goede parameter te zijn om avitale van vitale nieren te onderscheiden. Er is een sterke correlatie mel de warme ischaemie duur en het functionele resultat kan adequal voorspeld worden. Door een grenswarde voor aCST te definiềren (3000 $\mathrm{\mu g} / 100 \mathrm{~g}$ nierweefsel na 4 uur preservatie) en nieren net hogere waarden niet te transplanteren, kan voorkomen worden dat NFB donomieren die mel redelijke zekerheid PNF geven, getransplanteerd worden.

In dit proefschrift is aangetoond dat het potentieel aan NHB donoren minstens wecmaal zo groot is als hel potentieel aan HB donoren. Het op grote schaal invoeren wan NHB donatie protocollen zal hel tekort aan donomieren kunnen wegwerken. Mogelijk dat in de toekomsi ook andere organen van $\mathrm{NHB}$ donoren geaccepteerd kunnen worden voor transplantatie (bijwoorbeeld lever en longen). Dit gebeurt reeds incidenteel bij 'ideale' NHB donoren uit categorie 3. Het wijdverspreid uilvoeren van dergelijke NHB 
donaties zou ook voor deze organen kunnen betekenen dat hei telkort vermindert en mogelijk zelfs verdwijnt.

Belangrijk voor het op grote schaal invoeren van $\mathrm{NHB}$ donatie is de bekendheid van de procedure bij medisch personeel. Zij moeten immers potentiele donoren herkennen en bereid zijn een donatieprocedure in gang te zetten. De NHB donatieprocedure is relatief eenwoudig en het inbrengen wan een koelcatheter in de liesarterie, zoals beschreven in ons donatie protocol, kan bina overal uitgevoerd worden.

Voor nabestaanden lijkt donatie door een hartdode donor op z"n minst even acceptabel als donatie door een hersendode donor. In onze ervaring is het weigeringspercentage bij NHB donatie gelijk aan dat bij HA donatie; potentiele NHB donoren worden echter meestal niet als zodamig herkend. Voorlichting van publiek en medisch personeel is daarom essentied.

In Nederland staal de recent aangepaste wetgeving ten aanzien van orgaandonatie toe dat er voorbereidende handelingen verricht worden met het doel orgaantransplantatie mogelijk te maken. Het is dus bij NHB donatie toegestaan, wóorclat de expliciete wens van de overledene c.q. de nabestanden bekend is, een koelcatheter in te brengen en met het koelen van organen te begimen. Potentiële donoren zijn hierdoor makkelijker woor donatie beschikbaar en er kan sneller een donatieprocedure gestart worden. Daanaast zal het nieuwe centrale registratie systoem mensen de gelegenheid bieden zich te laten registreren als donor. Momenteel wordt warschijnlijk een flink deel van de potentiêle donaties niet gerealiseerd omdat de wens van de overledene niet bekend is en nabestaanden niet op tijd hun toestemming kunnen geven. Hopelijk biedt het registratie systeem een oplossing voor dit probleem en maakt het een succesvolle invoering van NHB donatie makkelijker. Waarschijnlijk alleen een "opting-our' wetgeving, warbinnen ledereen donor is tenzij bij leven anderszins geregistreerd, zal een max imaal benutten van het NHB donor potentieel mogelijk maken.

Uit onze studies blijkt dat MP als preservatiemethode voor NHB donomieren de eerste keus is. Met MP is het functionele resultaat van NHB donornieren beter dan met CS. Tevens kan gedurende MP de nier getest worden en dus Iransplantatie van avitale nieren worden voorkomen. Door tijdens MP $\alpha$ GST te bepalen, kan de schade aan de nier en daarmee de vabiliteit bepaald worden. De vrees een niet functionerende nier te transplanteren kan zo worden weggenomen. Dit zal de acceptatie van NHB donatie bevorderen en leiden tot meer donatieprocedures. Ondanks MP blijft DF vaker voorkomen bij NHB dan bij HB donomieren. Hoewel DF wordt gezien als een voorspeller van een slecht transplantatie resultaat op de lange termijn, is dit niet het geval bij onze NHB donomieren. Hoewel bij NFB donomieren DF 
dus niet vaker rejectie geeft noch vaker leidt tor verlies wan het transplantat, blyth het een negatief aspect. van het transplamteren van $\mathrm{NHB}$ donomieren.

Door preservatievloeistoffen speciall voor ischaenisch beschadigde nieren te ontwikkelen zou de ischaemische schade en dus DF behandelbaar kunnen worden. Uit dierexperimenteel onderzoek lijkt het mogelijk reperfusie schade te onderdnkken door de onvanger te behandelen (platelet-activating-lactor antagonist, adenosine remming) en zo DF te verminderen. Uhteraard dient additionele schade bij raeds ischaemisch beschadigde nieren tot een minimum beperki te bhijven en moet de nier onder de meest gunstige voonwarden getransplanteerd worden. Zo moeten ontwangers zorgvuldig geselecteerd worden, moet de preservatietijd zo kort mogelijk zijn en zou cyclosporne nefrotoxiciteit voonkomen kunnen worden met inductie immunotherapie.

MP speelt een belangrijke roll bij NHB nierdonatie en het lijkt wenselijk preservatiecentro op te zetten zodat NHB donornieren, en dan met name die nieren met vermoedelijk witgebreide ischaemische schado, machinaal gepreserveerd en op hun transplanteerbaarheid getest kumnen worden. In deze centra zal ook voortgaand onderzoek gedaan kunnen worden naar preservatiemeihoden voor ischaemisch beschadigde nieren en andere manieren om DF te verminderen. 
Procurement and Transplantation of Kidneys from Non-Heart-Beating Donors JHC Daemen, APA Oomen, EHJ Belgers, G Kootstra.

Digestive Surgery $1997 ; 14 ; 333-343$

\section{Categories of Non-Heart-Beating Donors}

G Kootstra, JHC Daemen, APA Oomen.

Transplantation Proceedings 1995; 23: 2893-2894

The Potential Pool of Non-Heart-Beating Kidney Donors

JHC Daemen, APA Oonnen, WPA Kelders, G Kootstra.

Clinical Transplantation 1997; 11:149-154

Short-term Outcome of Kidney Transplants from Non-Heart-Beating Donors after Preserwation by Machine Perfusion

JHC Daemen, RJ de Wit, MWGA Bronkhorst, ML Marcar, M Yin, E Heineman, G Kootstra

Transplant International 1996; 9 (suppl): 76-80

Effect of Machine Perfusion Preservation on Delayed Graft Function in Non-Heart-Beating Donor

\section{Kidneys}

JHC Daemen, B de Vries, APA Oomen, J DeMeester, G Kootstra

Transplant International 1997; 10:317-322

Kidney Transplantation from Non-Heart-Beating Donors

JHC Daemen, RJ de Wit, E Heineman, G Kootstra

Transplantation Reviews 1995; 9: 159-167

Glutathione S-transferase as Predictor of Functional Outcome in Tramsplantation of Machinc Preserved Non-Heart-Beating Donor Kidneys

JHC Daemen, APA Oomen, MA Janssen, L wan de Schoot, BK wan Kreel, E Heineman, G Kootstra Transplantation $1997 ; 63: 89-93$ 


\section{ABBREVIATIONS}

\begin{tabular}{|c|c|c|c|}
\hline $\mathrm{ALG}$ & antil leucocyte globulines & $\mathrm{ICU}$ & intensive care unit. \\
\hline AMP & adenine mono-phosphate & IF & immediate function \\
\hline ATG & anti T-lymphocyte globulines & $\operatorname{IRR}$ & intrarenal vascular resistance \\
\hline ATN & acute tubular necrosis & ISP & int-situ preservation \\
\hline ATP & adenine tri-phosphate & $\mathrm{LDH}$ & Hactite dehydrogethase \\
\hline $\mathrm{Ccu}$ & coronary care unit & MP & machine perfusion \\
\hline $\mathrm{CrT}$ & cold ischemia time & $\mathrm{NF}$ & non functioning \\
\hline $\mathrm{CS}$ & cold storage & NHB & non-hearmbeating \\
\hline CyA & cyclosporine A & NOT-TX & not transplanted \\
\hline DBTL & double-balloon-triple-lumen & OR & operating room \\
\hline DF & delayed function & $\mathbb{P}_{1}$ & inorganic phosphate \\
\hline $\mathrm{DP}$ & degradation products & $\mathbb{P M E}$ & phospluate monomester \\
\hline $\mathrm{EC}$ & Euro-Collins & p.m.p. & per million population \\
\hline $\mathrm{EEG}$ & ellectro encephalogram & 3IP-MRS & phosplworts ${ }^{31}$-magnetic resonarke \\
\hline ER & emergency room & & spectroscopy \\
\hline ET & Eurotransplant & PNF & primary non-function \\
\hline $\mathrm{F}$ & functioning & PRA & panel of reactive antibodies \\
\hline aGsT & $\alpha$ glutathione S-transferase & $\mathrm{PT}$ & proximal tubute \\
\hline $\mathbb{H B}$ & heart-beating & $\mathrm{SD}$ & standard deviation \\
\hline HLA & human lymphocyte antigens & SEM & standard error of the mean \\
\hline HTK & histidine tryptophane ketoglutarate & TAN & total adenine nucleotides \\
\hline \multirow[t]{2}{*}{$\mathbb{I C D}$} & international classification of & UW & University of Wiseonsin \\
\hline & diseases & WIT & warm ischemia vime \\
\hline
\end{tabular}


De afdeling Algemene Heelkunde wan het Academisch Ziekenhuis Maastricht heeft cen zekere traditie opgebouwd voor wat betreft non-heart-beating nierdonatie en preservatie. Biment deze traditie past ook. het tot stand komen van dit proefschrift, waarbij vele mensen direct en indirect betrokken ziin geweest. Deze betrokkenheid heeft zich met name afgespeeld op en rond het preservatielab in het az $\mathrm{M}$, doch ook op vele plaatsen ver daarbuiten. Op deze plaats wil ik graag allen die op hun eigen wijze een bijdrage hebben geleverd aan de genese van dit boekje, hiervoor hartelijk bedanken.

Speciale dank ben ik verschuldigd aan professor Gauke Kootstra die mij de mogelijkheid geboden heeft on binnen het onderzoeksproject naar de preservatie van donornieren, de onderzoeken uit te woeren die geleid hebben tot deze promotie. Je niet aflatend enthousiasme en inzet werken aanstekelijk. Het is een voorrecht geweest zo nauw met je te hebben samengewerkt. Bedankt. 
Jan-Willem Henri Catharina Daemen werd geboren op 18 maart 1966 te Geleen, Nedertand. Hier behaalde hij in 1984 aan de Scholengemeenschap St. Michiel zijn gymnasium-B diplona. Hij studeerde verwolgens geneeskunde aan de Rijksuniwersiteit Limburg te Mastricht; het arts diplomia volgde in maant 1991. Na zijn militaire dienstplicht vervuld te hebben als dienstplichtig bataljonsarts in het Noordduitse Seedorf, werd hij in augustus 1992 arts-assistent in het Scheperziekenhuis te Emmen. In „anuari 1994 keerde hij terug naar Maastricht om als arts-onderzoeker binnen de afdeling Algemene Heelkunde van het Academisch Ziekenhuis Maastricht, onder leiding van Prof.dr. G. Kootstra vorm te geven aan een Ontwikkelingsgeneeskunde Project naar de machinale preservatie van non-heart-beating donormieren. In 1996 werd het diepe zuiden wederom verruild voor het hoge noorden om te beginnen met de opteiding tot algemeen chirurg in de regio Groningen (opleider Prof.dr. R. van Schilfgaarde). Sinds juni van dat jaar is hij werkzaam als AGIO in het Sophia Ziekenhuis te Zwolle (opleider Dr. W. van Rooyen). 